Prepared in cooperation with the SOUTH PLATTE NATURAL RESOURCES DISTRICT

\title{
Evaluation of Ground Water Near Sidney, Western Nebraska, 2004-05
}

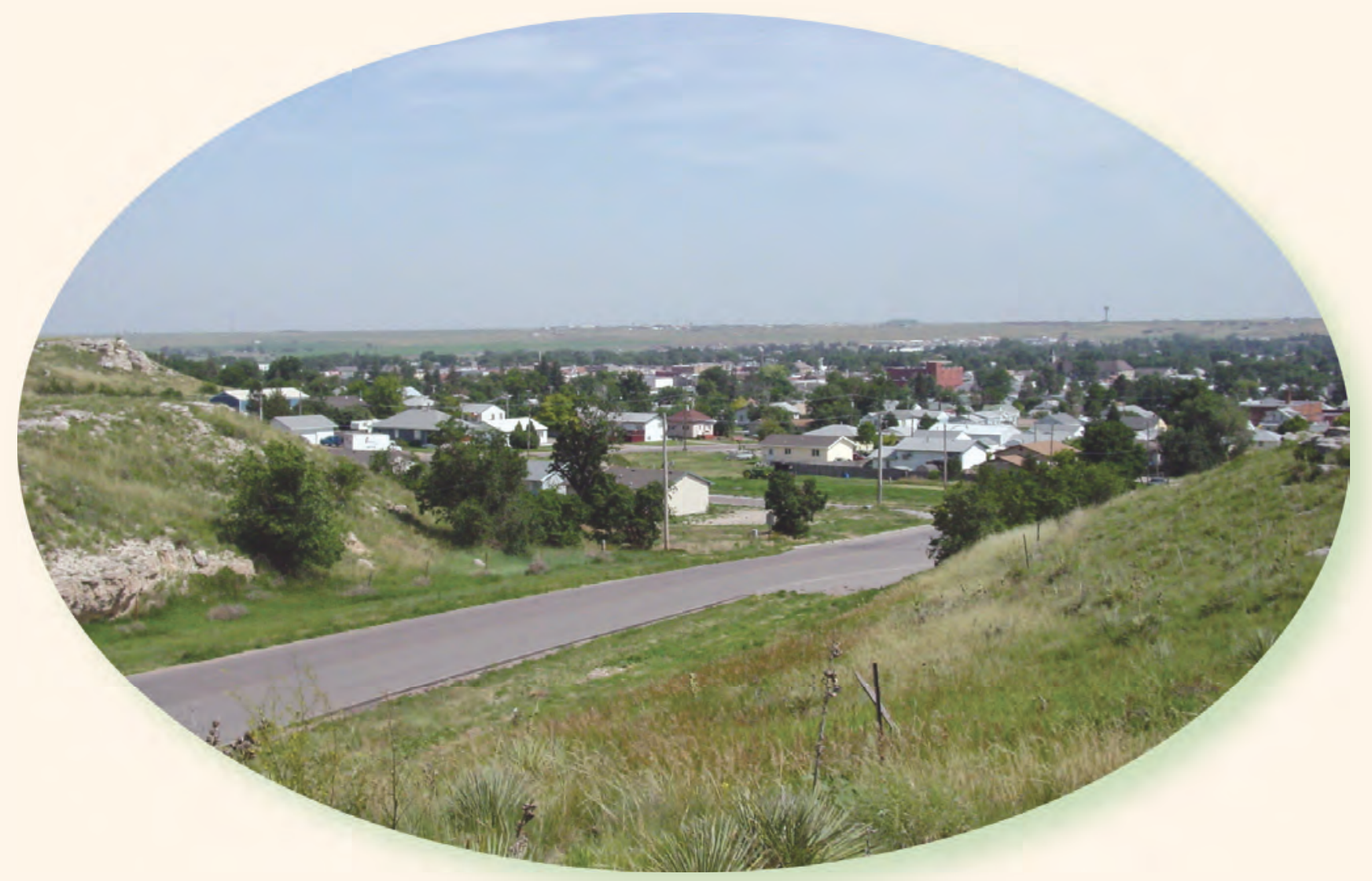

Scientific Investigations Report 2007-5086 



\section{Evaluation of Ground Water Near Sidney, Western Nebraska, 2004-05}

By G.V. Steele, S.S. Sibray, and K.A. Quandt

Prepared in cooperation with the South Platte Natural Resources District

Scientific Investigations Report 2007-5086 


\section{U.S. Department of the Interior DIRK KEMPTHORNE, Secretary}

\section{U.S. Geological Survey \\ Mark D. Myers, Director}

\section{U.S. Geological Survey, Reston, Virginia: 2007}

For product and ordering information:

World Wide Web: http://www.usgs.gov/pubprod

Telephone: 1-888-ASK-USGS

For more information on the USGS — the Federal source for science about the Earth, its natural and living resources, natural hazards, and the environment:

World Wide Web: http://www.usgs.gov

Telephone: 1-888-ASK-USGS

Any use of trade, product, or firm names is for descriptive purposes only and does not imply endorsement by the U.S. Government.

Although this report is in the public domain, permission must be secured from the individual copyright owners to reproduce any copyrighted materials contained within this report.

Suggested citation:

Steele, G.V., Sibray, S.S., and Quandt, K.A., 2007, Evaluation of ground water near Sidney, western Nebraska, 2004-05: U.S. Geological Survey Scientific Investigations Report 2007-5086, 54 p.

Cover photograph: View of Sidney, Nebraska, looking southeast along Haskell Hill Road (photograph by Barbara Steele, July 2005, used with permission). 


\section{Contents}

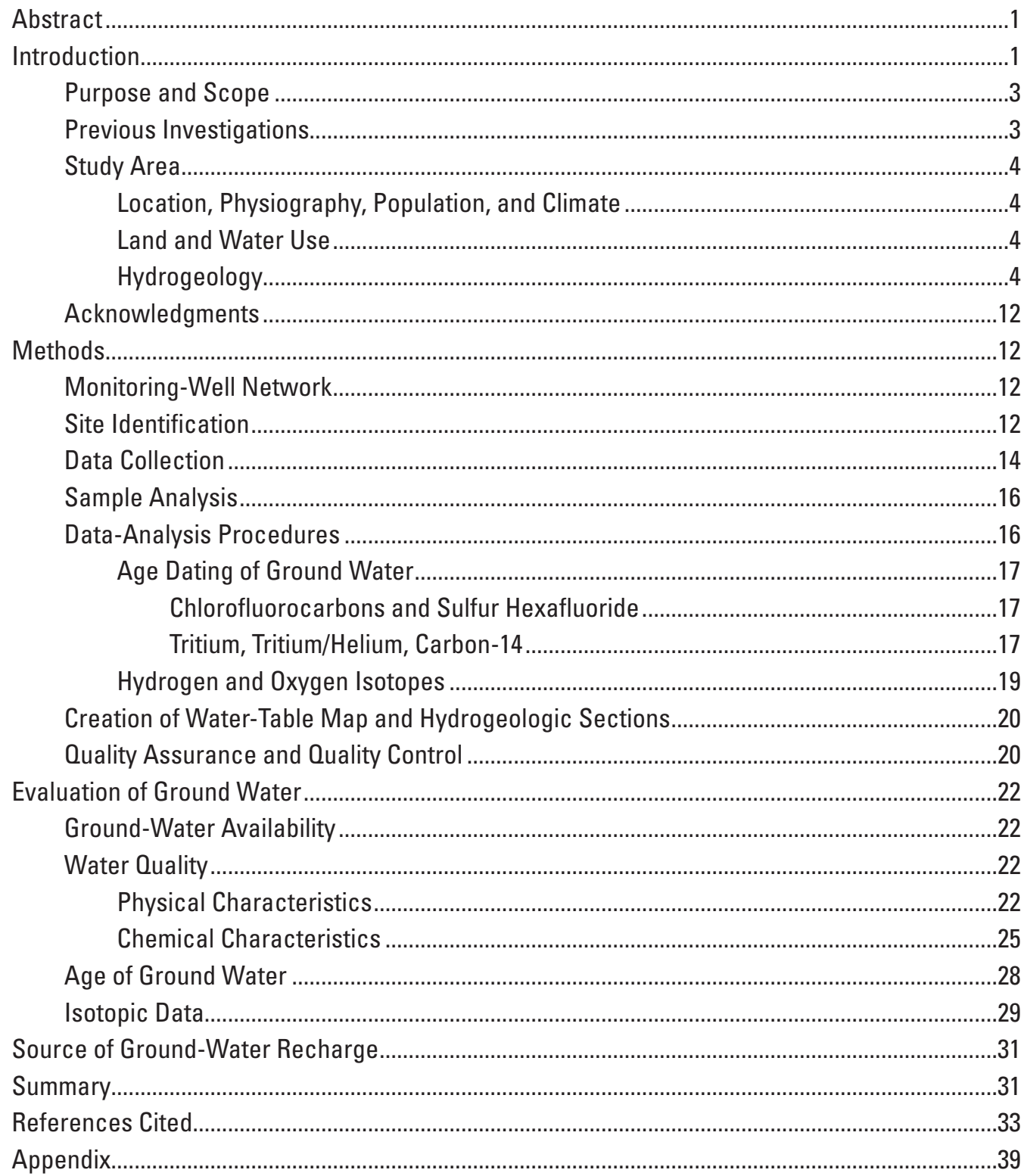

\section{Figures}

1-3. Maps showing:

1. Location of Lodgepole Creek study area in western Nebraska..................................

2. Land use in study area, 2005 ................................................................................

3. Generalized bedrock geology, and location of registered irrigation wells and

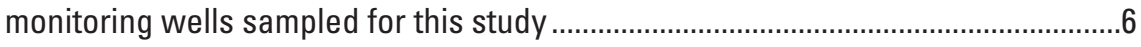

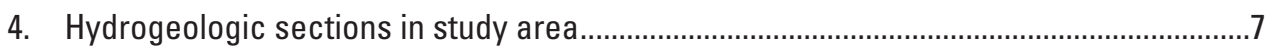

5. Map showing location of monitoring wells and test hole in study area..........................13

6. Schematic diagram of local well-numbering system ...................................................15 
7. Graph showing atmospheric concentrations of chlorofluorocarbons, tritium, and sulfur hexafluoride in North American air and carbon-14 concentrations in Northern Hemisphere air

8. Map showing generalized configuration of water table in study area, March 2005, and approximate direction of ground-water flow ....................................................................21

9. Graphs showing distribution of physical characteristics and water-quality constituents in study area, 2004-05

10. Trilinear diagrams showing ionic composition of ground water by aquifer and by location in the study area, 2004-05

11. Graph showing oxygen and stable hydrogen composition of water samples from study area, 2004-05

\section{Tables}

1. Hydrogeology of the Sidney study area, western Nebraska...........................................10

2. Summary statistics for physical characteristics and concentrations of major ions and nitrate in water samples from the Ogallala, Brule, and Brule sand aquifers near Sidney, western Nebraska, 2004-05.

3. Statistical comparison of median constituent concentrations in ground-water samples by aquifer and location near Sidney, western Nebraska, 2004-05 .....................................28

4. Results of synoptic water-level survey of monitoring and irrigation wells near Sidney, western Nebraska, March 2005

5. Results of water-quality analysis for physical characteristics, nutrients, stable isotopes, and dissolved gases in water samples from monitoring wells near Sidney, western Nebraska, 2004-05.

6. Results of water-quality analysis for major ions in water samples from monitoring wells near Sidney, western Nebraska, 2004-05.

7. Results of water-quality analysis for selected trace elements in water samples from monitoring wells near Sidney, western Nebraska, 2004-05

8. Results of analyses for age dating of ground water near Sidney, western Nebraska, 2004-05 
Conversion Factors, Abbreviations, Datums, and WaterQuality Units

\begin{tabular}{|c|c|c|}
\hline Multiply & By & To obtain \\
\hline \multicolumn{3}{|c|}{ Length } \\
\hline foot $(\mathrm{ft})$ & 0.3048 & meter $(\mathrm{m})$ \\
\hline inch (in.) & 2.54 & centimeter $(\mathrm{cm})$ \\
\hline mile (mi) & 1.609 & kilometer $(\mathrm{km})$ \\
\hline micrometer $(\mu \mathrm{m})$ & 0.00003937 & inch (in.) \\
\hline \multicolumn{3}{|c|}{ Area } \\
\hline acre & 4,047 & square meter $\left(\mathrm{m}^{2}\right)$ \\
\hline square mile $\left(\mathrm{mi}^{2}\right)$ & 259.0 & hectare (ha) \\
\hline \multicolumn{3}{|c|}{ Flow rate } \\
\hline foot per day $(\mathrm{ft} / \mathrm{d})$ & 0.3048 & meter per day (m/d) \\
\hline gallon per minute (gal/min) & 0.06309 & liter per second $(\mathrm{L} / \mathrm{s})$ \\
\hline inch per year (in/yr) & 25.4 & millimeter per year $(\mathrm{mm} / \mathrm{yr})$ \\
\hline \multicolumn{3}{|c|}{ Radioactivity } \\
\hline picocurie per liter (pCi/L) & 0.037 & becquerel per liter $(\mathrm{Bq} / \mathrm{L})$ \\
\hline \multicolumn{3}{|c|}{ Hydraulic conductivity } \\
\hline foot per day (ft/d) & 0.3048 & meter per day $(\mathrm{m} / \mathrm{d})$ \\
\hline \multicolumn{3}{|c|}{ Hydraulic gradient } \\
\hline foot per foot $(\mathrm{ft} / \mathrm{ft})$ & 0.3048 & meter per meter $(\mathrm{m} / \mathrm{m})$ \\
\hline \multicolumn{3}{|c|}{ Transmissivity* $^{*}$} \\
\hline foot squared per day $\left(\mathrm{ft}^{2} / \mathrm{d}\right)$ & 0.09290 & meter squared per day $\left(\mathrm{m}^{2} / \mathrm{d}\right)$ \\
\hline
\end{tabular}

Temperature in degrees Celsius $\left({ }^{\circ} \mathrm{C}\right)$ may be converted to degrees Fahrenheit $\left({ }^{\circ} \mathrm{F}\right)$ as follows:

$$
{ }^{\circ} \mathrm{F}=\left(1.8 x^{\circ} \mathrm{C}\right)+32 .
$$

Temperature in degrees Fahrenheit $\left({ }^{\circ} \mathrm{F}\right)$ may be converted to degrees Celsius $\left({ }^{\circ} \mathrm{C}\right)$ as follows:

$$
{ }^{\circ} \mathrm{C}=\left({ }^{\circ} \mathrm{F}-32\right) / 1.8 \text {. }
$$

Vertical coordinate information is referenced to the North American Vertical Datum of 1988 (NAVD 88).

Horizontal coordinate information is referenced to the North American Datum of 1983 (NAD 83).

Altitude, as used in this report, refers to distance above the vertical datum.

*Transmissivity: The standard unit for transmissivity is cubic foot per day per square foot times foot of aquifer thickness [(ft3/d)/ft'] ft. In this report, the mathematically reduced form, foot squared per day $\left(\mathrm{ft}^{2} / \mathrm{d}\right)$, is used for convenience.

Specific conductance is given in microsiemens per centimeter at 25 degrees Celsius $(\mu \mathrm{S} / \mathrm{cm}$ at $\left.25^{\circ} \mathrm{C}\right)$.

Concentrations of chemical constituents in water are given either in milligrams per liter (mg/L) or micrograms per liter $(\mu \mathrm{g} / \mathrm{L})$.

Concentrations of isotopic units are given either in parts per thousand (per mil), tritium units (TU), or percent modern carbon (pmC). 


\title{
Evaluation of Ground Water Near Sidney, Western Nebraska, 2004-05
}

\author{
By G.V. Steele, S.S. Sibray, and K.A. Quandt
}

\section{Abstract}

During times of drought, ground water in the Lodgepole Creek area around Sidney, western Nebraska, may be insufficient to yield adequate supplies to private and municipal wells. Alternate sources of water exist in the Cheyenne Tablelands north of the city, but these sources are limited in extent. In 2003, the U.S. Geological Survey and the South Platte Natural Resources District began a cooperative study to evaluate the ground water near Sidney.

The 122-square-mile study area lies in the south-central part of Cheyenne County, with Lodgepole Creek and Sidney Draw occupying the southern and western parts of the study area and the Cheyenne Tablelands occupying most of the northern part of the study area. Twenty-nine monitoring wells were installed and then sampled in 2004 and 2005 for physical characteristics, nutrients, major ions, and stable isotopes. Some of the 29 sites also were sampled for ground-water age dating.

Ground water is limited in extent in the tableland areas. Spring 2005 depths to ground water in the tableland areas ranged from 95 to 188 feet. Ground-water flow in the tableland areas primarily is northeasterly. South of a ground-water divide, ground-water flows southeasterly toward Lodgepole Creek Valley.

Water samples from monitoring wells in the Ogallala Group were predominantly a calcium bicarbonate type, and those from monitoring wells in the Brule Formation were a sodium bicarbonate type. Water samples from monitoring wells open to the Brule sand were primarily a calcium bicarbonate type at shallow depths and a sodium bicarbonate type at deeper depths. Ground water in Lodgepole Creek Valley had a strong sodium signature, which likely results from most of the wells being open to the Brule. Concentrations of sodium and nitrate in ground-water samples from the Ogallala were significantly different than in water samples from the Brule and Brule sand. In addition, significant differences were seen in concentrations of calcium between water samples from the Ogallala and the Brule sand. Median concentrations of nitrate varied by aquifer-2.6 milligrams per liter (Ogallala), 2.1 milligrams per liter (Brule), and 1.3 milligrams per liter (Brule sand).
The chemistry of the ground water in the study area indicates that ground water flows from recharge areas in both the tableland areas and Lodgepole Creek Valley to discharge areas beyond the study area. Recharging water that percolates into the Ogallala in the tableland areas either enters the Ogallala aquifer, flows along the Ogallala-Brule contact, or enters Brule fractures or sand. Although limited in amount, ground water flowing along the Ogallala-Brule contact or in the Brule fractures or sand appears to be the predominant means by which water moves from the tableland areas to Lodgepole Creek Valley.

Apparent ground-water ages from chlorofluorocarbon and sulfur hexafluoride data generally were similar. Age of ground water for most monitoring wells located in Lodgepole Creek Valley ranged from the mid- to late 1960s to the early 1990s. Ages of ground water in samples from monitoring wells located in tableland draw areas ranged from the mid1980s to the early 1990s. Water in the Brule (areas without known secondary permeability structures) or deeper Brule sand aquifer was substantially older than water in the Ogallala aquifer and probably was recharged between 10,000 to 30,000 years before present.

The stable isotopic data indicate that the ground water in the study area probably originated from precipitation. Ground water in Lodgepole Creek and the tableland areas are similar in chemistry. However, there appears to be limited interaction between ground water within the Ogallala to the north of Sidney and Lodgepole Creek Valley. Available data indicate that although some of the ground water in the Ogallala likely flows across the Ogallala-Brule contact, most of it does not move toward Lodgepole Creek.

\section{Introduction}

Ground water in the Lodgepole Creek area of western Nebraska (fig. 1) currently (2006) is developed to the extent that during times of drought sufficient yields may not be available for private and municipal supplies. Municipal supplies for Sidney, Nebraska, originally were drawn from aquifers located in Lodgepole Creek Valley. Because these supplies later were 

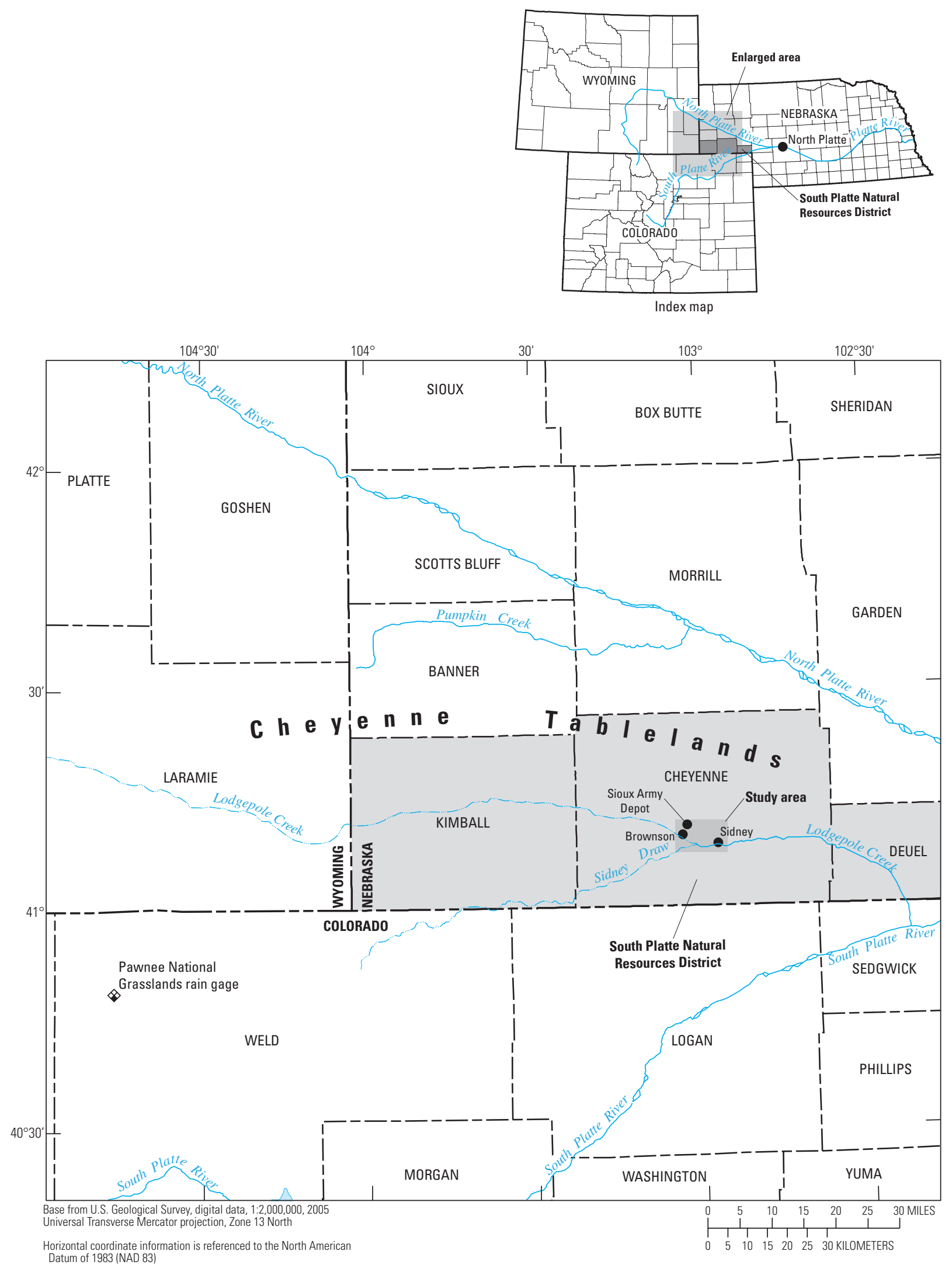

Figure 1. Location of Lodgepole Creek study area in western Nebraska. 
determined to be inadequate for the demands of the city, officials assessed foreseeable needs and sought alternate sources.

In the Sidney area, the immediate sources of water were in the Cheyenne Tablelands north of the city. Although the City of Sidney later installed municipal supply wells there to augment its municipal wells in Lodgepole Creek Valley, fundamental ground-water data still remained sparse in the Cheyenne Tablelands as well as the uplands south of Lodgepole Creek Valley (herein after both areas are undifferentiated and referred to as tableland areas). In some tableland areas ground water is more plentiful than in Lodgepole Creek Valley; whereas, in other areas the ground-water system is thought to be limited in thickness or nonexistent.

In addition, the ground-water source area for the Kilham well field directly north of Sidney may include an area downgradient of the former Sioux Army Depot. In 2000, the U.S. Army Corps of Engineers (USCOE) reported ground-water contamination from 4-amino-2,6-dinitrotoluene and hexahydro-1,3,5-trinitro-1,3,5-triazine (RDX) at the ammunitions workshop in this depot (U.S. Army Corps of Engineers, 2000). Although USCOE reported that these contaminants appear to be localized, no comprehensive ground-water-quality studies have been completed to investigate the chemical characteristics of the ground-water source area for Sidney's Kilham well field (not depicted on any maps) or how the ground water in the tableland areas interacts with ground water in Lodgepole Creek Valley. Therefore, knowledge of ground-water quality and flow in the tableland areas and how it relates to groundwater flow in Lodgepole Creek Valley would provide additional understanding of the overall system.

To address these concerns, the U.S. Geological Survey (USGS) in cooperation with the South Platte Natural Resources District (NRD) and with assistance from the University of Nebraska-Lincoln Conservation and Survey Division (CSD) investigated the ground-water flow and quality in the tableland areas and in Lodgepole Creek Valley in an area generally lying between the communities of Brownson and Sidney (fig. 1). This study can provide the managers of the South Platte NRD with improved understanding of groundwater flow in the area north of Sidney and how ground water in the tableland areas interacts with ground water in Lodgepole Creek Valley. Also, this study will enable (1) the Cooperative Hydrologic Study (COHYST) to gain field data to refine their regional ground-water-flow model (http://cohyst.dnr.ne.gov, accessed February 20,2007) and (2) will allow other resources managers to better understand the dynamics of similar systems in Nebraska or the Nation.

\section{Purpose and Scope}

The report describes an evaluation of ground water near Sidney in western Nebraska. The methods used to select and install the monitoring wells and to collect and analyze water samples are described. The report presents generalized ground-water interactions between the tableland areas and Lodgepole Creek Valley. The purpose of this report is to describe the general movement of water between the tableland areas and shallow aquifers in Lodgepole Creek Valley using ground-water-level measurements made during March 2005 and the results of the analysis of ground-water samples collected to determine: (1) the general water chemistry of ground water in the tableland areas and in the fractured Brule Formation and shallow alluvial aquifers adjacent to and underlying Lodgepole Creek; (2) the age of ground water through analyses of chlorofluorocarbons, tritium, ratios of tritium/helium, sulfur hexafluoride, and carbon-14; and (3) the source of water through analysis of hydrogen and oxygen isotopes.

\section{Previous Investigations}

Selected previous investigations that describe regional geology and include Lodgepole Creek Valley are Darton (1903), Meinzer (1923), Lugn (1935), Tychsen (1954), Bjorklund (1957), Smith (1969), Swinehart and others (1985), Goodwin and Diffendal (1987), Bryda (1988), Diffendal (1990), South Platte NRD (1994), Gottula (1997), and Bishop-Brogden Associates, Inc. (William Taylor, City of Sidney, written commun., 2003). Bryda (1988), in an unpublished master's thesis, reported on nitrate concentrations in ground water in and around Sidney. Gottula (1997) described water-quality conditions from a study of nonpoint-source ground-water contamination in eastern Cheyenne County (from Sidney east to the Cheyenne-Deuel County line). Gottula (1997) primarily focused on large nitrate concentrations in ground-water samples from Lodgepole Creek Valley. Regional water-quality reports that include at least part of Lodgepole Creek Valley include Engberg and Spalding (1979), Engberg (1984), and Engberg and Druliner (1988).

Tychsen (1954), in an unpublished doctoral dissertation, described in detail the sedimentary structure of the Brule Formation. According to Tychsen (1954), the Brule Formation of northwest Nebraska is composed of 56 to 93 percent silt with minor amounts of sand, clay, volcanic ash, and coarser channel sand and gravel. Fluvial channel sand is especially prominent in parts of the basal Brule Formation. Bjorklund (1957) reported that the Brule Formation is a brittle siltstone. However, local areas of sandy or argillaceous material may exist. The Brule Formation typically weathers into blocks and slabs, and lenticular beds of volcanic ash, sandstone, and fragments of siltstone are present locally in regular but indistinct bedding planes. In addition, Bjorklund (1957, p. 13) reported the existence of a permeable zone underlying parts of Lodgepole Creek in the vicinity of Cheyenne County and Sidney Draw and stated, "The zone is 10 to 15 feet thick and pinches out toward the sides of the valleys." Bishop-Brogden Associates, Inc. (William Taylor, City of Sidney, written commun., 2003) reported the transmissivity of the channel sand in the tableland areas at $27,000 \mathrm{ft}^{2} / \mathrm{d}$, the hydraulic conductivity at about $600 \mathrm{ft} / \mathrm{d}$, and the specific yield ranging between 0.2 and 0.25 . 


\section{Study Area}

This section describes the general aspects of the study area. Specifically, the location, physiography, land and water use, and the hydrogeologic characteristics of the study area are discussed.

\section{Location, Physiography, Population, and Climate}

The 122-mi study area (fig. 1) lies in the High Plains section of the Great Plains Province (Fenneman, 1946) and in the south-central part of Cheyenne County, Nebraska, and wholly within the South Platte NRD. The South Platte NRD lies in the southern portion of the Nebraska panhandle, which is bordered by Wyoming to the west and Colorado to the south.

The South Platte NRD is characterized by two topographically distinct regions - upland plains and incised valleys of the Platte Valley lowlands (which includes Lodgepole Creek). The upland plains that make up the largest portion of the NRD are moderately rolling in topography. These plains were incised by Lodgepole Creek and its tributaries. Lodgepole Creek and Sidney Draw compose part of the southern and western extent of the study area, whereas the Cheyenne Tablelands cover most of the northern part of the study area.

Sidney, with an estimated 2004 population of 6,381 (U.S. Census Bureau, 2006), is the larger of the two communities in the study area. The other community within the study area is unincorporated Brownson, whose population is very small and was not listed in the U.S. Census Bureau's data (2006).

Climatic conditions in the study area are typical of semiarid midcontinental areas located near the base of mountains. The climate (from normal precipitation and monthly temperature listings for Sidney 6 North Northwest (NNW) for the period of 1948 to 2005) is characterized by relatively light annual precipitation (16.4 in/yr), a high evaporation rate, and a wide range of daily average temperatures $\left(9.9\right.$ to $\left.72.4^{\circ} \mathrm{F}\right)$ $\left(-12.3\right.$ to $22.4^{\circ} \mathrm{C}$ ) (High Plains Regional Climate Center, 2006). The winters are cold, and the summers are short and hot. About 80 percent of the precipitation is received as rain during April through September. Most of the precipitation occurs during intense thunderstorms that commonly occur in the region.

\section{Land and Water Use}

Agriculture dominates the land cover of the study area. The principal land cover types in Lodgepole Creek Valley are a combination of corn, rangeland, pasture, other grass, alfalfa, small grains, and summer fallow (fig. 2). In the study area, nonirrigated cropland is the largest land use, followed by rangeland and irrigated cropland. Grazing (range, pasture, and grass), conservation reserve program (CRP), and the City of Sidney incorporate the next largest group of land uses. The percentage of irrigated land tends to increase from west to east
(Center for Advanced Land Management Information Technologies, 2005) and is predominantly located in Lodgepole Creek Valley.

Ground-water supplies are a vital resource to the South Platte NRD. Domestic, municipal, and industrial water uses are solely supplied from ground water. Stock water can be derived from either ground water or surface water. Both ground water and surface water are used for irrigation in the South Platte NRD, but within the study area the only source of water for irrigation is ground water.

In the study area, Lodgepole Creek Valley is intensively irrigated with several wells open to aquifers in the fractured Tertiary-age Brule Formation or both the fractured Brule Formation and the overlying Quaternary-age alluvial aquifer. The saturated thickness of the alluvial aquifer is too thin to yield sufficient quantities of water alone; therefore, irrigation wells that are open to the alluvial aquifers also are augmented with supplies from fractures within the Brule Formation. Land uses in the tablelands, by contrast, are predominantly nonirrigated cropland and rangeland with sparsely distributed irrigation wells developed in the Ogallala or discrete channel deposits in the Brule Formation (fig. 3).

In the early 1900s, ground water was developed for irrigation in Lodgepole Creek Valley around Sidney. Several wells were drilled in the 1920s, and one well was drilled in 1913 just west of Sidney on State land. Currently (2006) within the South Platte NRD, Lodgepole Creek Valley has fewer than 700 registered irrigation wells (Nebraska Department of Natural Resources, 2006). In the same area, irrigated land was capped at about 43,200 acres when the South Platte NRD formed the Lodgepole Creek Integrated Ground Water Management Subarea in October 2002. Within this subarea, a moratorium was imposed on drilling of new large-capacity wells (greater than $50 \mathrm{gal} / \mathrm{min}$ ), and a stay, in accordance with LB962 (Nebraska Law LB962 regarding integrated management of ground-water and surface-water resources), was established on the expansion of irrigated acres. These actions were in response to declining flows of surface water and declining ground-water levels in areas along Lodgepole Creek.

\section{Hydrogeology}

Lodgepole Creek is the predominant watercourse of the South Platte NRD. Flows in Lodgepole Creek within the study area typically are ephemeral or intermittent. However, localized areas of flow can occur during certain times of the nonirrigation season (October to April). Lodgepole Creek, which almost runs the entire length of the South Platte NRD, begins in the Sherman Mountains (not shown on any maps) of southeastern Wyoming. The largest tributary to Lodgepole Creek, Sidney Draw, is an ephemeral drainage that begins in Colorado and enters Nebraska in southeast Kimball County. Sidney Draw Valley runs in a northeasterly direction to the confluence of Sidney Draw with Lodgepole Creek approximately $2 \mathrm{mi}$ west of Sidney (fig. 3). Several other small unnamed 


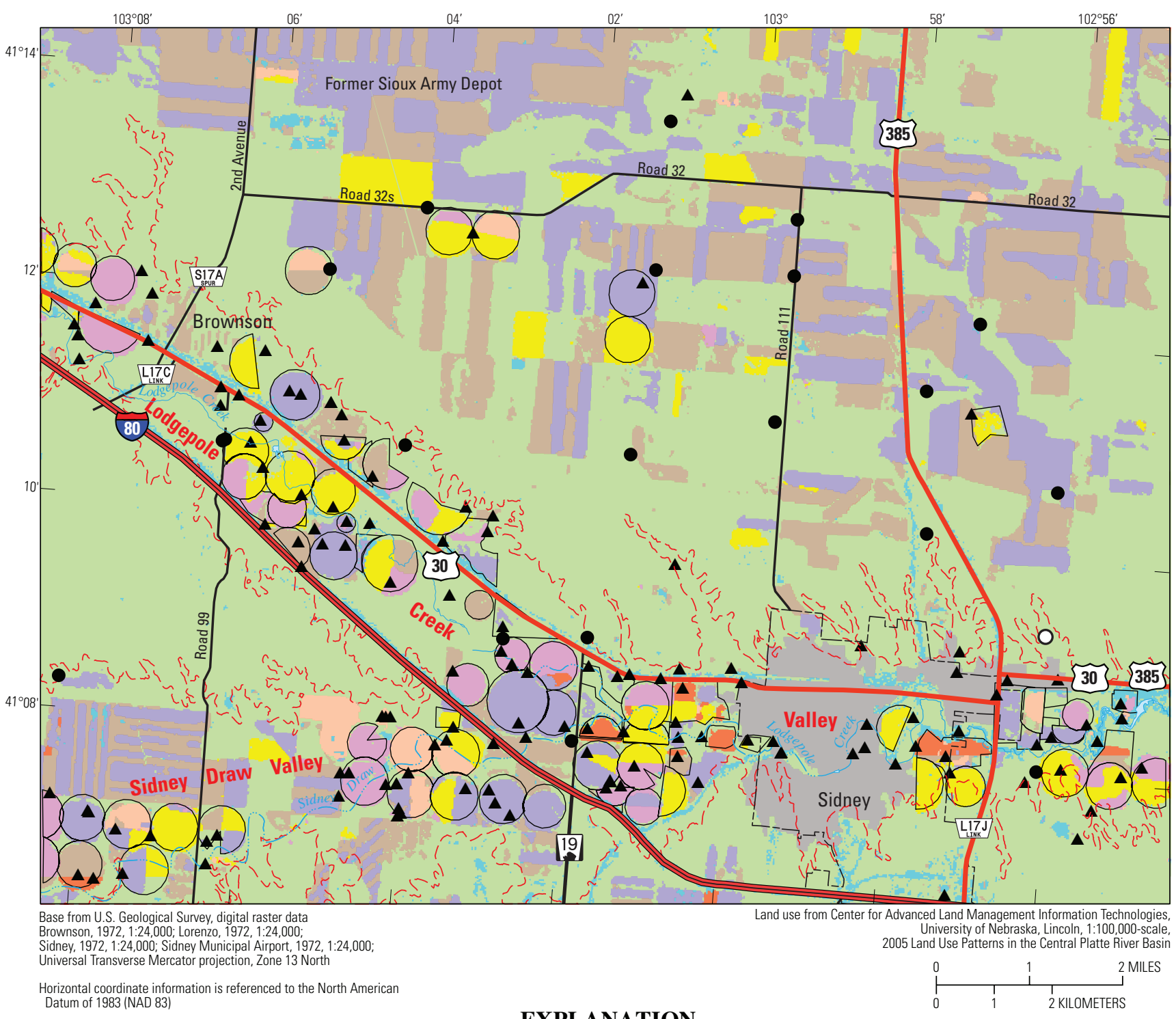

EXPLANATION

Alfalfa

Corn

Range, pasture, grass-Includes conservation reserve program lands

Small grains

Sunflower

Summer fallow

Other cropland-Includes dry edible beans, potatoes, sorghum (milo, sudan), soybeans, and sugar beets
Urban areas

Other-Barren lands, open water, riparian forests and woodlands, roads, and wetlands

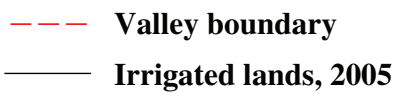

- Monitoring-well location

○ Test-hole location

- Registered, active irrigation well

Figure 2. Land use in the study area, 2005. 


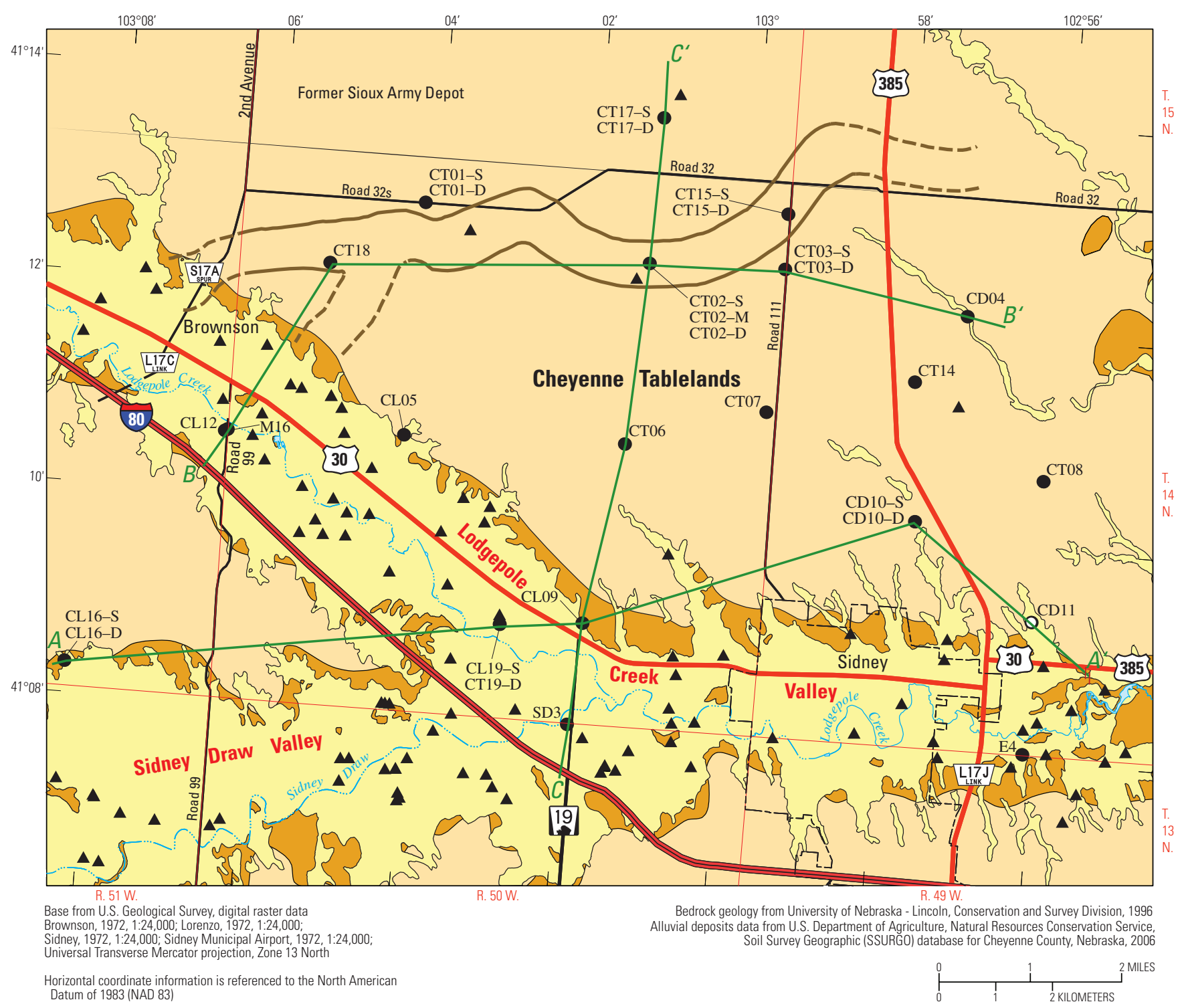

EXPLANATION

\section{Bedrock geology}

$\mathbf{Q}_{\mathbf{a}} \quad$ Undifferentiated alluvial and colluvial deposits

To Tertiary-aged Ogallala Group

$\mathbf{T}_{\mathbf{w r}}$ Tertiary-aged White River Group, Brule Formation

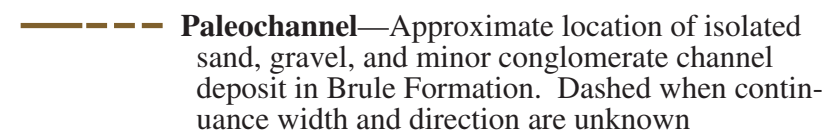

$A-A^{\prime} \quad$ Trace of section shown in figure 4

$\Delta$ Registered, active irrigation well

CT02-S

CT02-M

Monitoring-well location and identifier $-\mathrm{S}$ indicates well-screen interval was shallow. M indicates wellscreen interval was at medium depth. D indicates wellscreen interval was deep

${ }^{\mathrm{CD} 11} \mathrm{O}$ Test-hole location and identifier

Figure 3. Generalized bedrock geology, and location of registered irrigation wells and monitoring wells sampled for this study.

ephemeral channels drain into the Lodgepole Creek Valley during times of high-intensity rainfall.

The hydrogeologic sections (fig. 4), constructed from data collected during installation of the monitoring-well network used in this study, help describe the surficial groundwater resources in the study area. The surficial aquifers in the study area are limited to three geologic units - the Quaternary-age alluvium found along Lodgepole Creek, the Tertiaryage Ogallala Group (Miocene), and the Brule Formation of the White River Group (Oligocene) (table 1). These three geologic units are separated by two major erosional unconformities described by Swinehart and Diffendal (1997). 


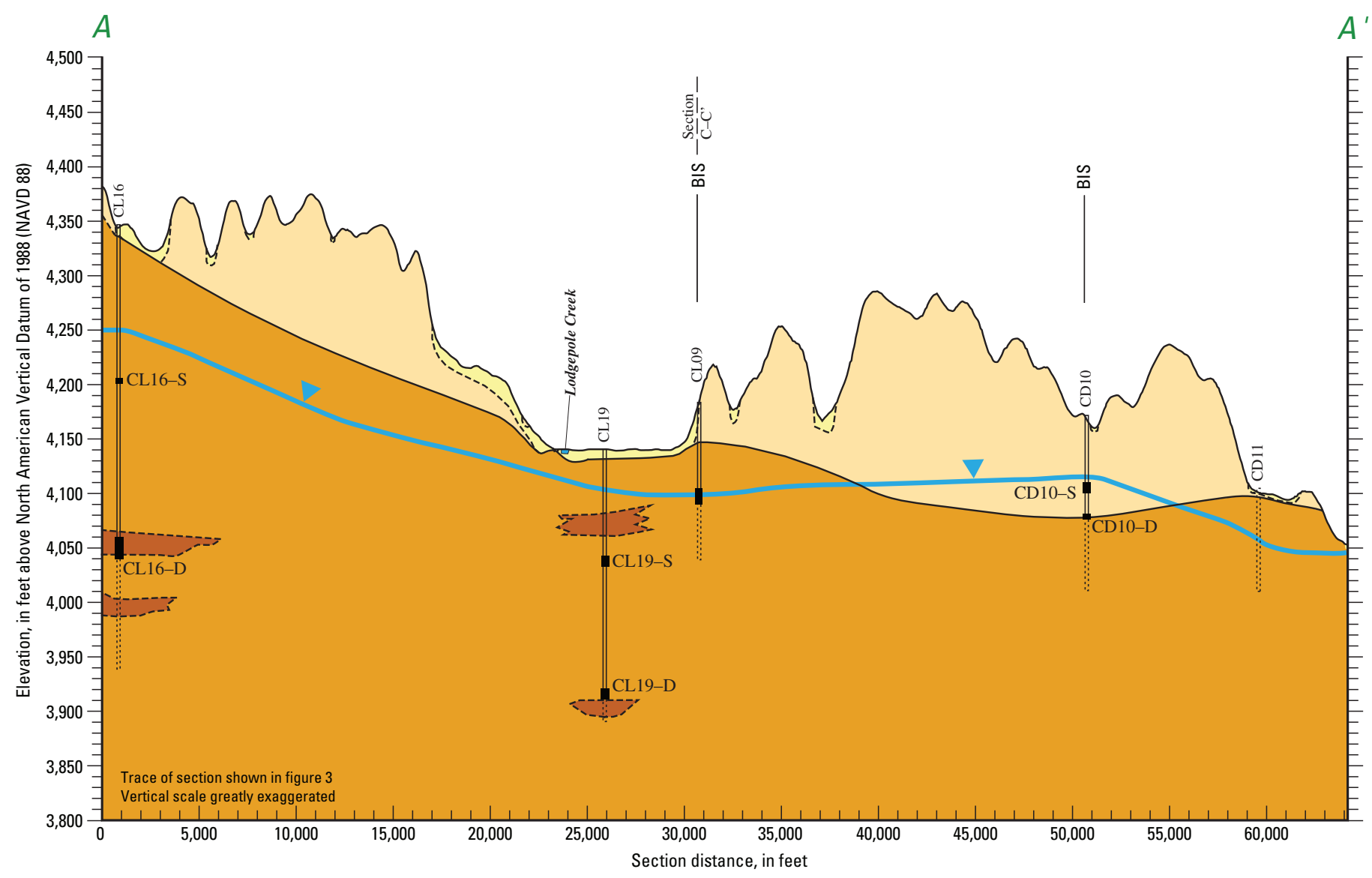

EXPLANATION

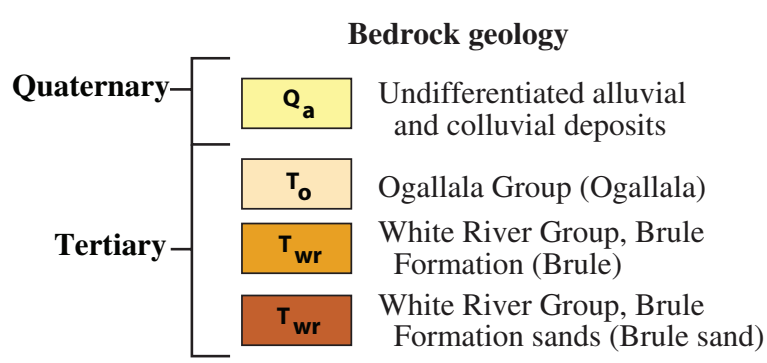

Figure 4. Hydrogeologic sections in study area.

The Brule Formation of the White River Group (hereinafter referred to as the Brule) underlies the Quaternary-age undifferentiated alluvial, colluvial, and eolian deposits in Lodgepole Creek Valley and the Ogallala Group (herein after referred to as the Ogallala) in the tableland areas. The Brule largely consists of beds of siltstone that in the study area can exceed $600 \mathrm{ft}$ in thickness, but which do not yield substantial quantities of water unless fractured. The Brule also contains local isolated paleochannel deposits of sand and gravel that can yield moderate volumes of water for irrigation wells. One paleochannel deposit of sand, gravel, and minor conglomerate was encountered while installing monitoring wells for this study in the tableland areas north of Lodgepole Creek Valley (fig. 3). This channel deposit was as much as $22 \mathrm{ft}$ thick, and it can be delineated by water wells and numerous oil wells in the area. This deposit also can be traced for $6 \mathrm{mi}$ and appears to be about $0.5 \mathrm{mi}$ in width (fig. 3). Additional isolated zones of sand and (or) sandstone that are capable of yielding smaller volumes of water occur within the Brule, but these deposits are smaller, thinner, and are not mappable.

In much of the study area, the Brule is a confining unit unless secondary permeability develops. Bjorkland (1957) noted that horizontal zones of fracturing in the Brule underlying Lodgepole Creek Valley and Sidney Draw vary from 10 to $15 \mathrm{ft}$ in thickness, and that the fracture zones were an important source of water for large-capacity irrigation wells. Barrash 


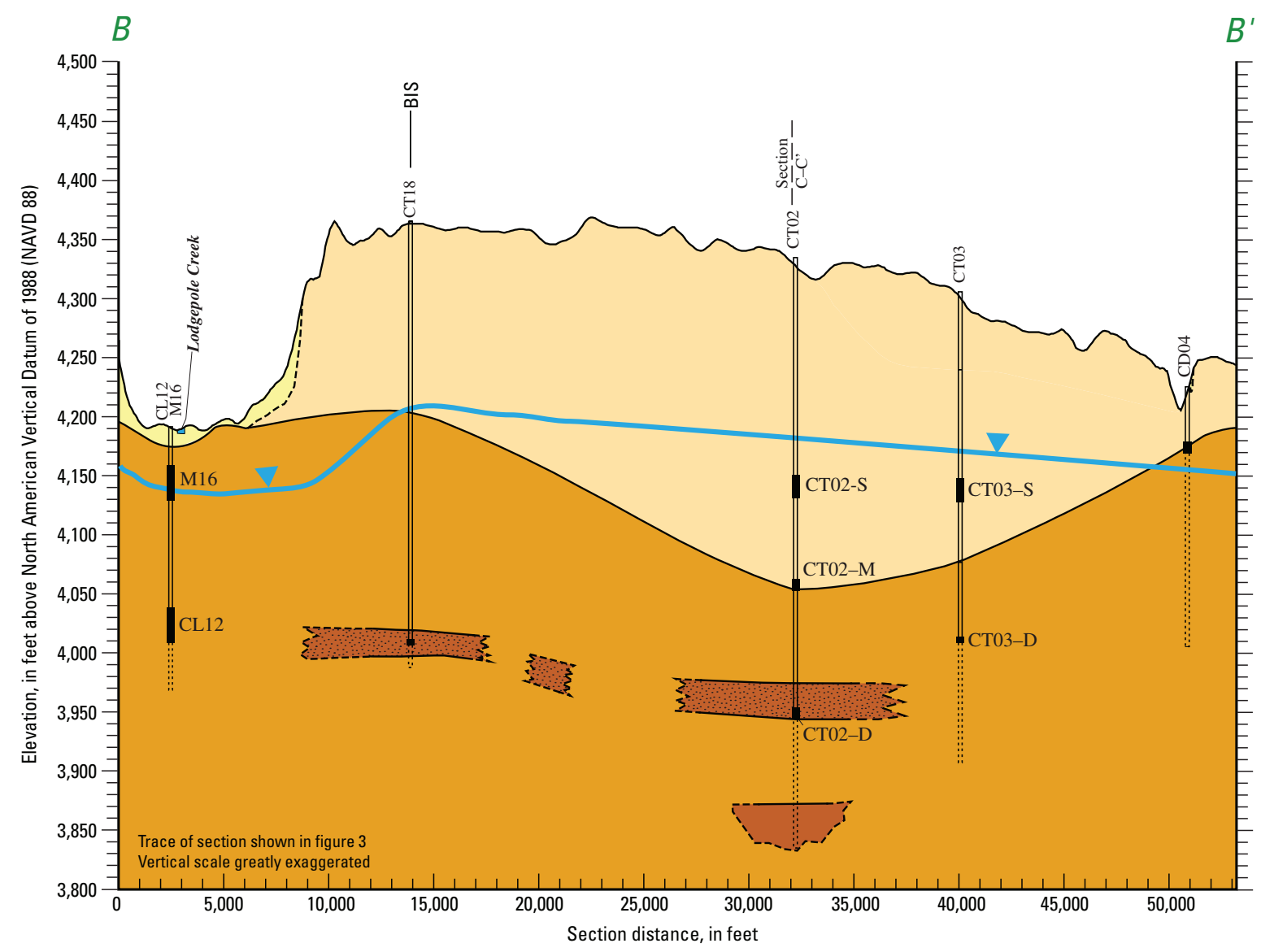

EXPLANATION

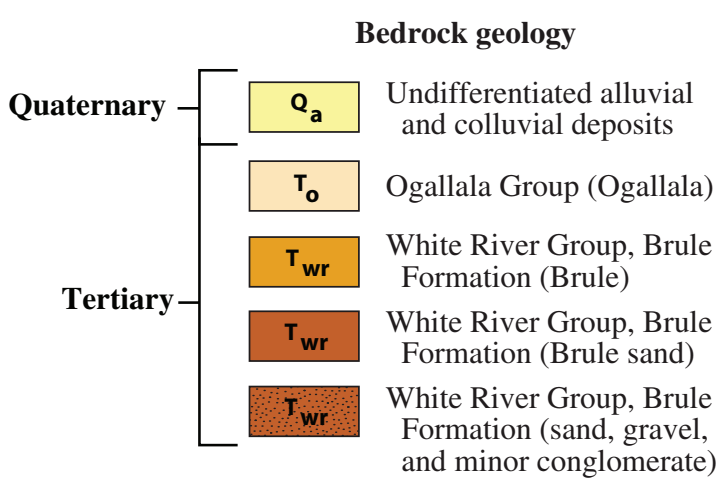

Figure 4. Hydrogeologic sections in study area.-Continued

(1986) also noted that the intensely fractured zone he studied in the Sidney Draw area was horizontal to subhorizontal. Lowry (1966) reported that the secondary permeability of the White River Group likely resulted from the presence of pipes that formed prior to deposition of the overlying Ogallala. Pipes are tubular cavities in the rock that in the study area often are filled with sand and gravel. These pipes, instead of fractures, could account for some of the secondary permeability of the Brule. Lowry (1966) also reported that large-capacity wells were not known to have been drilled outside major valleys. It is possible that the piping and the fracturing might be related.

Geologic contact-Dashed where inferred

\section{March 2005 water level}

CT02-S

CT02-M

BIS
Well-screen interval and well identifier-Dashed line indicates test hole. S indicates well-screen interval was shallow. M indicates well-screen interval was at medium depth. D indicates wellscreen interval was deep

\section{Bend in section}

The authors hypothesize that piping and intensely fractured horizontal secondary permeability zones of the Brule in the study area may have had a three-step origin. During the initial phase of the development of secondary permeability, piping occurred in the vadose zone accompanied by erosion and lowering of the water table during the development of a major erosional unconformity. The piping may or may not have been affected by unloading due to erosion of the overlying material. Although this process could have occurred at any time during development of a major unconformity, the distribution of these zones of secondary permeability suggest 


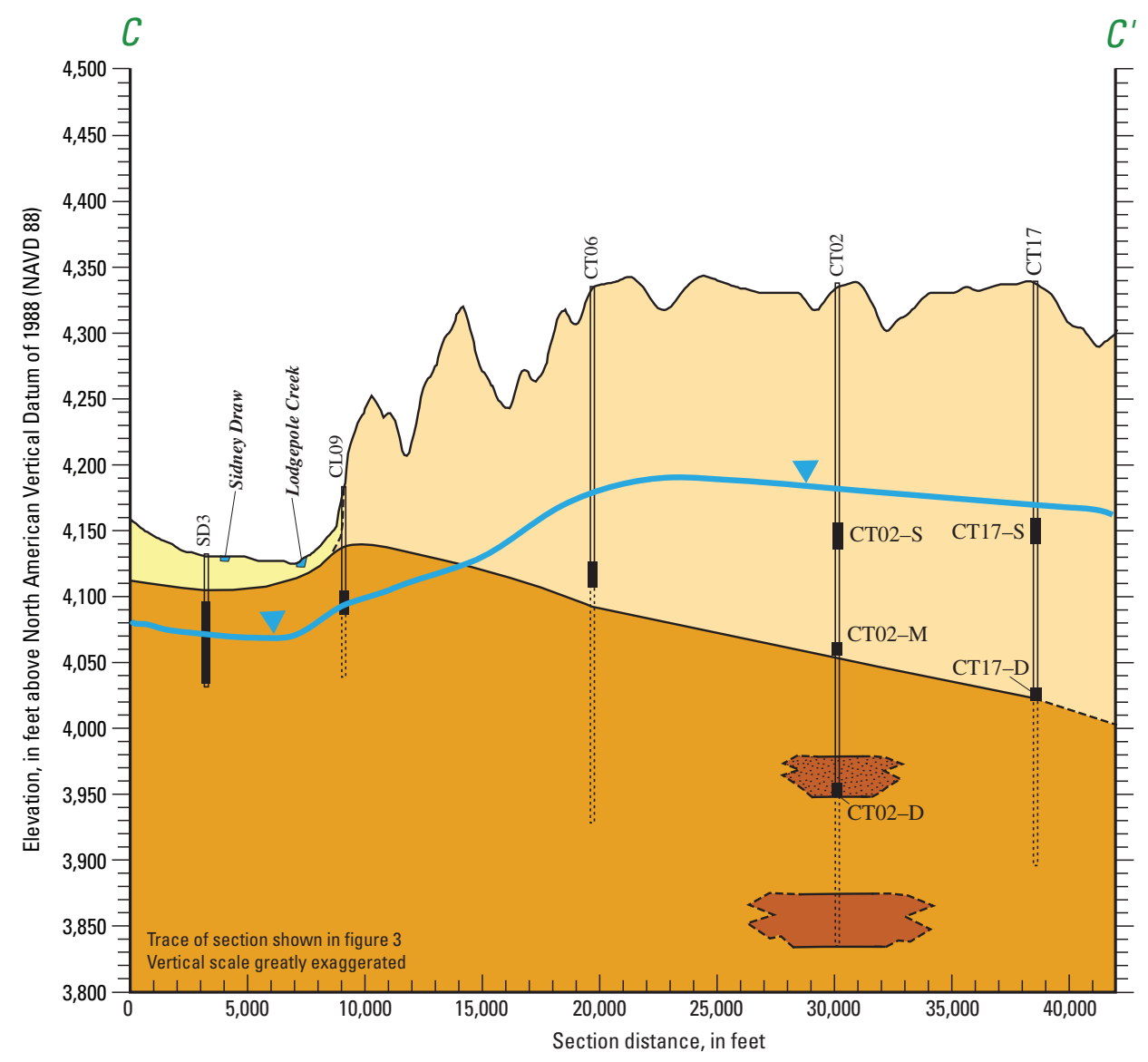

EXPLANATION

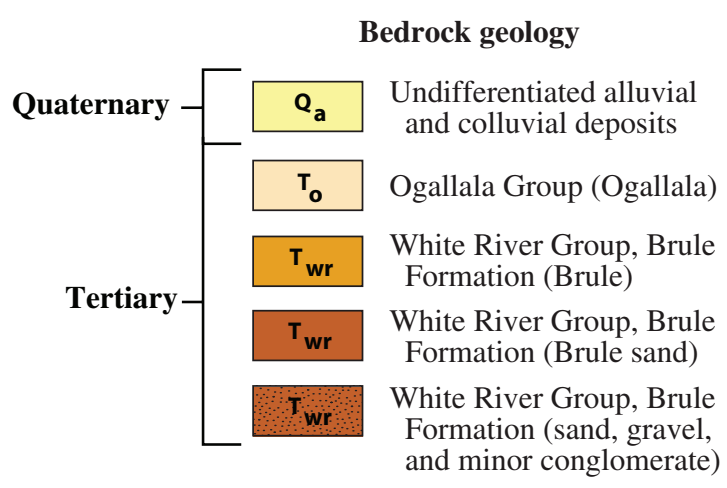

Figure 4. Hydrogeologic sections in study area.-Continued

that this erosion and related piping probably occurred during the development of the present-day Lodgepole Creek drainage system prior to the deposition of the alluvial deposits. It also is possible that this process may have occurred during development of the erosional unconformity prior to deposition of the Ogallala. During the second phase, subsurface erosion continued in the vadose zone, and removal of localized zones of very fine-grained sand would have caused the collapse or mechanical failure of the overlying low-yield beds of siltstone resulting in the intensely fractured horizontal to subhorizontal zones observed today. During the final phase of aquifer development, the ground-water level rose to fill the fractured zones during or shortly after the deposition of the alluvial material. Subsurface erosional and horizontal fracture zone development essentially would end or become minimal when the vadose zone became saturated and the relatively slow movement of ground water minimized subsurface erosion. This unconformity process is similar to the development of secondary permeability in carbonate aquifers except that mechanical erosion of fine-grained material here is more important than chemical dissolution.

In Lodgepole Creek Valley, the Brule is considered a major aquifer where fractured because of its ability to yield large quantities of water with little drawdown. In areas where the Brule is an unfractured siltstone, it is considered to be the 


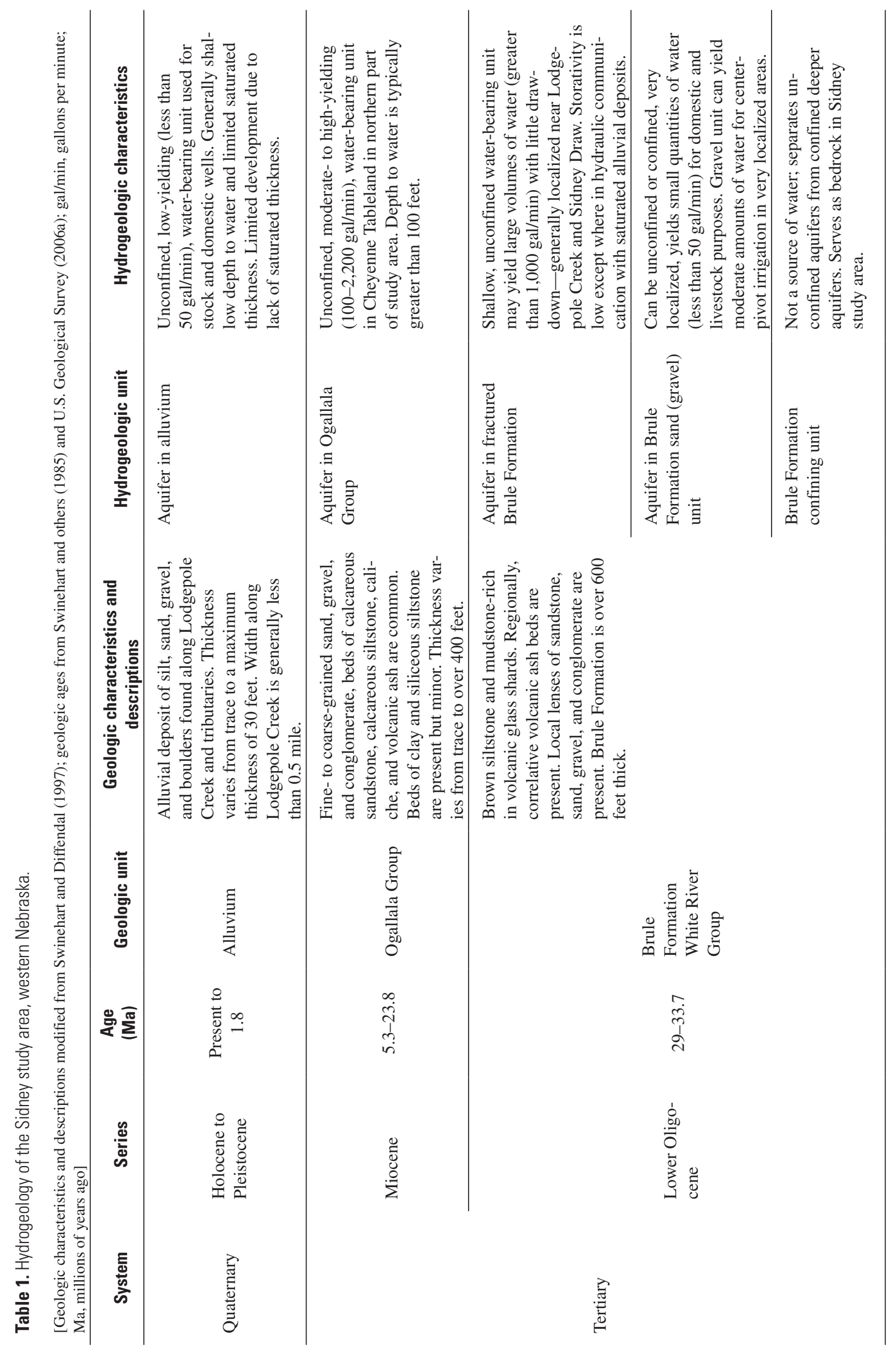


base of the shallow alluvial aquifer system in the Lodgepole Creek Valley. The top of the Brule under the tableland areas is considered the base of the regional aquifer system where (1) the Brule is mantled by saturated Ogallala deposits and (2) data show no occurrence of secondary permeability zones within the Brule. In the Lodgepole Creek drainage, myriad fracture zones are present where the Brule is at or near land surface (Sibray and Zhang, 1994), making it one of two principal aquifers in the South Platte NRD. Although fracture zones can allow substantial yields from production wells open to the Brule, the storage coefficient is very low (Sibray and Zhang, 1994). Because of the small storage coefficient, during prolonged drought ground-water levels fluctuate substantially, and the Brule can be drained easily, resulting in smaller or insufficient yields to irrigation wells.

Where the Brule is fractured, hydraulic conductivity and well yields in the study area likely are similar to those reported by Barrash and Ralston (1991) and Sibray and Zhang (1994) in the Sidney Draw area located about 6 mi west of the study area. Barrash and Ralston (1991) reported values of hydraulic conductivity that ranged from 3,000 to $11,000 \mathrm{ft} / \mathrm{d}$, whereas Sibray and Zhang (1994) studied the same fracture zones and reported a higher hydraulic conductivity value of 20,000 ft/d. Crist and Borchert (1972) reported transmissivity values from aquifer tests in southeast Wyoming ranging from about 12,800 to $32,600 \mathrm{ft}^{2} / \mathrm{d}$ in Brule wells. The Sibray and Zhang (1994) study used a finite-difference numerical ground-water flow model (McDonald and Harbaugh, 1988) and the response of piezometers above and below the fracture zone to construct a three-dimensional model of the aquifer. The piezometers located below the main fracture zone in the Sibray and Zhang (1994) study had a slower response time, indicating lack of vertical fractures at depth. Their study also showed enhanced permeability between the main fracture zone and the water table. Rapp and others (1957) estimated hydraulic conductivity values for the unfractured White River Group to be less than $2.7 \times 10^{-2} \mathrm{ft} / \mathrm{d}$. Barrash (1986) reported that hydraulic conductivity values measured from core samples of representative lithologies (siltstone to claystone) in the Brule ranged from $2.4 \times 10^{-5}$ to $8.2 \times 10^{-1} \mathrm{ft} / \mathrm{d}$.

The Ogallala is the youngest Tertiary-age deposit in the South Platte NRD. Rocks from the Ogallala are widespread, and subsequent erosion has exposed older units in the Lodgepole Creek drainage and in Sidney Draw. The Ogallala consists of alternating interbedded layers of clay, silt, and sand and gravel. These materials were deposited by streams that filled their valleys or channels with sediment and, subsequently, spilled over and left a widespread blanket deposit of intermixed coarse and fine materials above older units. In some locations, the Ogallala is cemented with calcium carbonate or silica and does not yield water to wells. In other locations, there are individual beds of unconsolidated sand and gravel deposits with little or no silt and thicknesses of $70 \mathrm{ft}$ or more. The Ogallala is an important aquifer north of Lodgepole Creek in the tableland areas, and this aquifer discharges some water to Lodgepole Creek Valley.
Diffendal (1990) reported that the "Sidney Gravel" of the Ogallala cannot be traced for more than a few kilometers from its type areas. Furthermore, no gravel sheet (Sidney Gravel ${ }^{1}$ ) occurs beneath the Kimball Formation ${ }^{1}$ of the Ogallala within the regional area described by Diffendal (1990). Therefore, the sand and gravel units of the Ogallala in the region are largely discontinuous remnant deposits.

Where sufficient saturated sediments occur, which excludes those areas where the Brule crops out or the Ogallala is above the water table, the Ogallala is the major source of water for most of the South Platte NRD. The aquifer in the Ogallala is a good source of water where saturated. The reported range of yield from registered irrigation wells in Cheyenne County north of Lodgepole Creek Valley is about 100 to 2,200 gal/min (Nebraska Department of Natural Resources, 2006) with an average production of about $820 \mathrm{gal} / \mathrm{min}$. Bishop-Brogden Associates, Inc. (William Taylor, City of Sidney, written commun., 2003) reported transmissivity values of channel sand in the tableland areas north of Sidney to be about $27,000 \mathrm{ft}^{2} / \mathrm{d}$, the hydraulic conductivity was about $600 \mathrm{ft} / \mathrm{d}$, and the specific yield ranged between 0.20 and 0.25 . However, because of predominantly consolidated sediments throughout the Ogallala, the hydraulic conductivity values generally are much less than reported by BishopBrogden Associates, Inc. (as they were describing localized unconsolidated channel sand). Typical specific yield and hydraulic conductivity values of the Ogallala aquifer likely are similar to 0.15 to 0.16 and 14 to $19 \mathrm{ft} / \mathrm{d}$, respectively, in central Nebraska (Peckenpaugh and Dugan, 1983), and 0.10 to 0.20 and 25 to $100 \mathrm{ft} / \mathrm{d}$, respectively, in the Northern High Plains aquifer (Gutentag and others, 1984). Ogle and Hallberg (2000) reported a transmissivity value for the Ogallala under confined conditions in southeastern Wyoming as about $1.1 \mathrm{ft}^{2} / \mathrm{d}$. Because of a lack of saturated thickness, the Ogallala in the immediate study area yields only moderate amounts of water to a relatively small number of irrigation wells.

South of Lodgepole Creek, the Ogallala is mostly unsaturated because the elevation of the water table approximately corresponds with the top of the underlying Brule. North of Lodgepole Creek, the Brule has been eroded to deeper levels, and there is a greater saturated thickness of the Ogallala. Also, areas of the Ogallala can contain paleochannels that largely are unmapped.

The youngest and shallowest aquifer in the study area is alluvium along Lodgepole Creek and its tributary ephemeral drainages. These deposits are relatively thin over most of the study area and, because of a lack of saturated thickness, generally are not regarded as a major source of water. Although there is water in the alluvial deposits, the most important aspect of the deposits is that they provide groundwater recharge to some wells completed in the underlying fractured Brule. In addition, some alluvial wells can yield small quantities of water for livestock and domestic use in some localized areas.

\footnotetext{
${ }^{1}$ Nomenclature is from the University of Nebraska-Lincoln.
} 
The alluvial deposits consist of heterogeneous mixtures or lenticular beds of silt, sand, and gravel with scattered pebbles, cobbles, and boulders deposited along Lodgepole Creek and its tributaries. These deposits generally are continuous but usually are less than $0.5 \mathrm{mi}$ in width. In addition, some of the alluvial sediment can become dry during the irrigation season (May through September) when the large-capacity irrigation wells in the fractured Brule are pumped.

\section{Acknowledgments}

This study conducted in cooperation with the South Platte NRD was made possible by support provided by the Nebraska Environmental Trust. Acknowledgment is extended to the landowners who provided access for the installation of monitoring wells and the collection of ground-water-quality samples. Special appreciation and acknowledgment are extended to Sean Sutherland and Linda Suhr of the South Platte NRD for assistance with sampling or clerical requirements during this study.

\section{Methods}

This section describes the methods used to collect and analyze ground-water data for the study area. Data collected for this study included both new data collected during 2004-05 and historical data from the USGS National Water Information System (NWIS) database, the South Platte NRD, the CSD, the city of Sidney, and the Nebraska Oil and Gas Commission.

\section{Monitoring-Well Network}

Water-level measurements and water samples from the study area were collected from 3 existing monitoring wells and from 26 monitoring wells installed specifically for this study (fig. 5). Criteria for site selection included (1) placement of monitoring wells in a grid to utilize horizontal transects, and (2) placement of some monitoring wells in tableland areas, tableland draws, and Lodgepole Creek Valley to determine ground-water characteristics in the tableland areas, Lodgepole Creek Valley, and the transitional area between these two topographic regions. The pattern of the grid originally was established to semiuniformly distribute the monitoring wells in the tableland areas. Permission to install monitoring wells from landowners and a lack of saturated deposits necessitated modifications to the original grid. Once all permissions were set, monitoring wells were installed by USGS, South Platte NRD, and CSD personnel using methods similar to those described by Lapham and others (1997).

Each monitoring well was identified by the predominant formation in which it was completed-Ogallala, Brule, or Brule sand. All monitoring wells installed for this study were open to either the Ogallala or the Brule. Monitoring wells that were open to the Ogallala were identified as Ogallala monitoring wells, and those open to the Brule were identified either as Brule monitoring wells or as Brule sand monitoring wells (if they were open to Brule sand). Because of the limited thickness of the alluvium, no monitoring wells open only to the alluvial deposits were available, and subsequently, any monitoring wells partially open to alluvial deposits were identified as Brule or Brule sand monitoring wells.

The Brule underlying Lodgepole Creek Valley appears to be composed of secondary permeability structures as evident from the many irrigation wells present in the valley. However, none of these structures were identified during the installation of the monitoring wells. Therefore, as stated previously, all monitoring wells open to the Brule were identified as either Brule or Brule sand and not fractured Brule. Because secondary permeability structure in the Brule exists (as discussed in the section on "Hydrogeology"), monitoring wells in Lodgepole Creek Valley that were open to the Brule likely contained some of these secondary permeability structures. Moreover, because myriad secondary permeability structures exist, an important caveat is that this report will loosely classify the Brule as an aquifer although in many cases, especially in the tableland areas, the Brule acts as a confining unit where sand units are not available. To support this classification, results of significance testing between yields of monitoring wells in Lodgepole Creek Valley compared with the tableland areas are presented in the section on "Ground-Water Availability."

Following installation of the new monitoring wells in 2003, air sparging was used for monitoring-well development. Air sparging uses compressed air to lift water up and out of the monitoring well. This, in turn, discharges sediment-laden water from the well. All monitoring wells were secured with padlocks and protected with well protectors. Monitoring wells that extended above grade were protected using steel well protectors. Monitoring wells that were below grade were sealed from the environment using flush-mount well protectors.

\section{Site Identification}

Four different methods of site identification were used in this report. The first method, the field identifier (such as CT18), was used to easily identify the monitoring wells during onsite operations or during discussions and was based largely on either an historical identifier (existing monitoring wells) or new identifier (monitoring wells installed for this study). Existing monitoring wells used during this study (E4, M16, and SD-3) retained the identifier historically used by the South Platte NRD, and all were located in Lodgepole Creek Valley. Monitoring wells installed for this study used a field identifier nomenclature associated with the placement of the monitoring well that was based on the county, topography, and depth and uses an alpha-numeric identification (such as CT01D). All new monitoring wells were in Cheyenne County, so the first alpha character " $C$ " was used to designate Cheyenne 


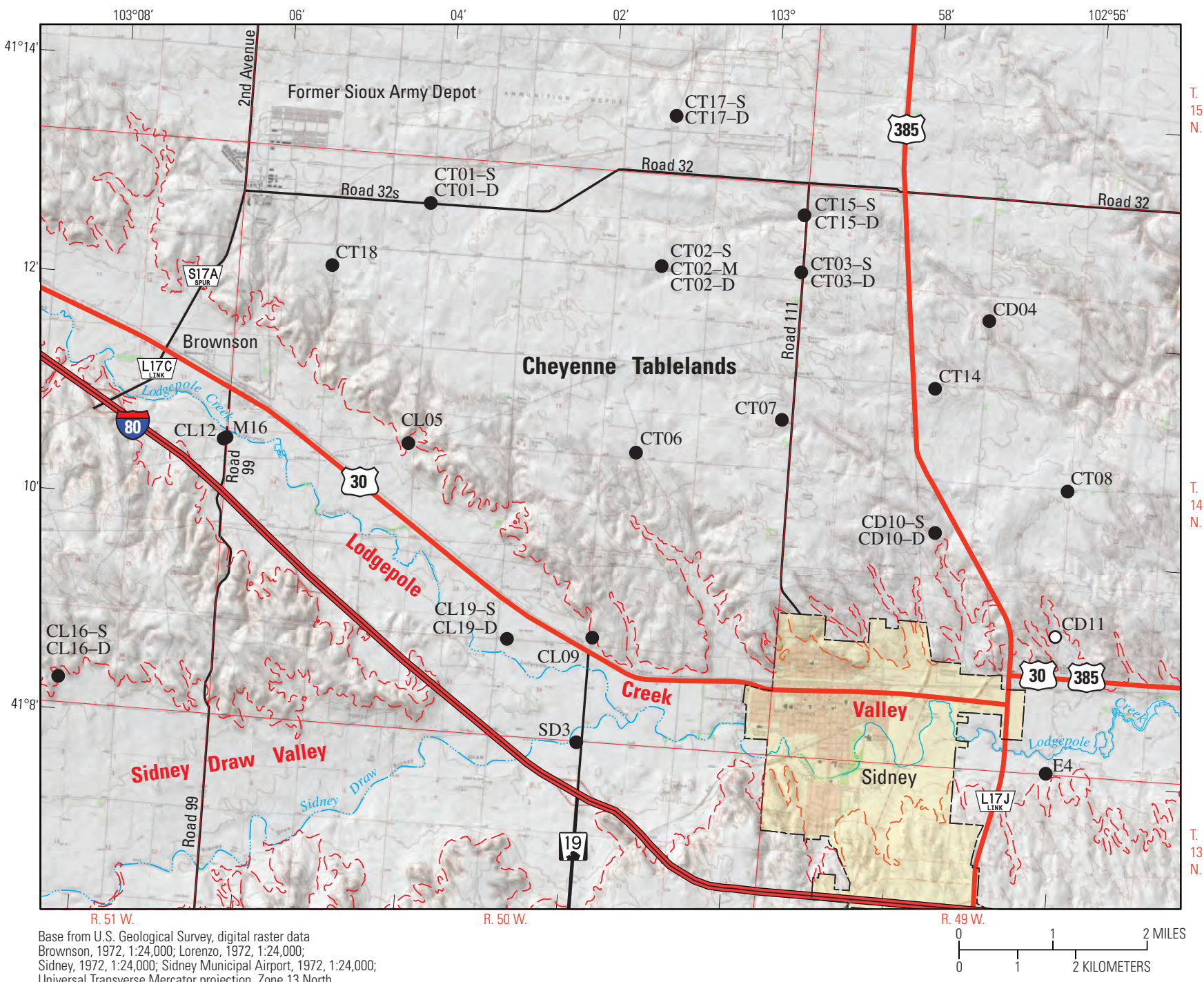

Sidney, 1972, 1:24,000; Sidney Municipal Airport, 1972, 1:24,000

Universal Transverse Mercator projection, Zone 13 North

Horizontal coordinate information is referenced to the North American Datum of 1983 (NAD 83)

\section{EXPLANATION}

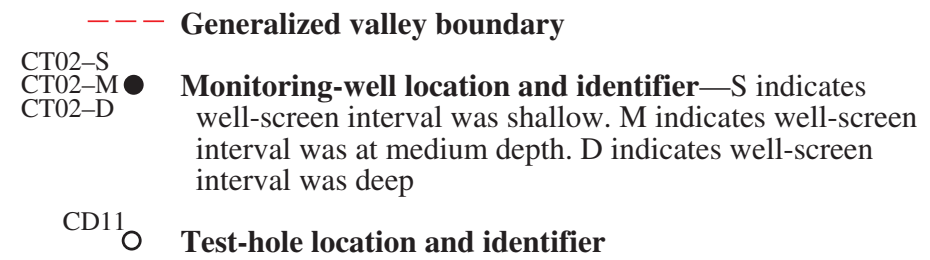

Figure 5. Location of monitoring wells and test hole in study area. 
County. The next alpha character "T," "D", or "L" was used to identify where the monitoring well was located—tableland areas (T), in a draw (D) connecting the tableland areas to Lodgepole Creek Valley, or in Lodgepole Creek Valley (L). The numeric value in the field identifier represents the well's numeric identification with respect to field identification. The terminal alpha character, if present, was used to identify the relative depth of the monitoring well in the well cluster, rather than depth of the well as a function of the land surface. The shallow monitoring wells were designated by an "S," and the maximum well-screen depths for those wells ranged in depth from 57 to $357 \mathrm{ft}$ below land surface (sites containing a single monitoring well also were included in this statistic). Only one monitoring well contained an intermediate-depth well screen (well CT02-M). This well was identified with an "M" and had a maximum well-screen depth of $276 \mathrm{ft}$ below land surface. The deep monitoring wells were designated by " $\mathrm{D}$," and maximum well-screen depths ranged from 94 to $500 \mathrm{ft}$ below land surface.

The second method uses the USGS site-identification number. USGS assigns a unique number to each type of sampling site when it is established. The identification numbers for wells are assigned according to the grid system of latitude and longitude. The number consists of 15 digits; for example 411214103052001. The first six digits denote the degrees, minutes, and seconds of latitude, the next seven digits denote degrees, minutes, and seconds of longitude, and the last two digits (assigned sequentially) identify the wells within a 1second grid. This site-identification number, once assigned, is a pure number and has no locational significance.

The third method, a local identifier (such as $14 \mathrm{~N} 50 \mathrm{~W}$ 14CDCA1), is based on the land subdivisions in the Public Land Survey System (fig. 6). The number preceding N (north) of the Base Line indicates the township, the number preceding W (west) of the Principal Meridian indicates the range, and the number preceding the terminal letters indicates the section in which the well is located. The terminal letters designated $\mathrm{A}, \mathrm{B}, \mathrm{C}$, and $\mathrm{D}$, denote the quarter section, the quarter-quarter section, the quarter-quarter-quarter section, and the quarterquarter-quarter-quarter section, respectively. The designation is given in a counterclockwise direction beginning with " $\mathrm{A}$ " in the northeast corner of each subdivision. Each well also is assigned a terminal number " 1 " designating the order of well inventory. Two or more wells are further distinguished by incrementing the terminal digit of the local identifier, assigned by order of inventory.

The fourth method, used in table 4 (in the Appendix), is the Nebraska Department of Natural Resources ground-water well registration number. This number is required for all wells, with limited exclusions (Nebraska Department of Natural Resources, 2002), and is provided to help the reader obtain additional information on each well.

\section{Data Collection}

Ground-water levels were measured in 36 monitoring, 1 observation, and 20 irrigation wells in the study area during March 2005 (table 4 in Appendix). Measurements were made to the nearest $0.01 \mathrm{ft}$ using a steel or electric tape. Groundwater samples were collected from 29 monitoring wells, processed, and shipped according to methods described in Kolpin and Burkart (1991), Wilde and Radtke (1999), Wilde and others $(1999,2004)$. Ground-water samples were collected twice from 29 sites-April 2004 and April 2005. At all sites, water levels were measured concurrently with the collection of water-quality samples. Ground-water samples were collected using a stainless-steel submersible pump connected to a flowthrough chamber. Physical characteristics (specific conductance, $\mathrm{pH}$, and water temperature) and dissolved oxygen were measured in the flow-through chamber until three well-casing volumes were purged and measurements stabilized (Wilde and Radtke, 1999), or until the well had been pumped dry and the water level allowed to recover.

Excluding the initial equipment blank, all environmental and quality-control (QC) samples were collected and processed onsite. Samples requiring filtration [major ions, nutrients, and carbon- $\left.14\left({ }^{14} \mathrm{C}\right)\right]$ were filtered during sample collection using a clean, disposable $45-\mu \mathrm{m}$ filter. Field equipment was cleaned and decontaminated immediately following sample collection. Samples were sent to analytical laboratories within 2 days of the collection. Samples preserved by cooling (nutrients) were packed on ice in coolers to maintain a maximum temperature of $4{ }^{\circ} \mathrm{C}$ while enroute to the analytical laboratory (explained in next section). Remaining samples were packed in coolers without ice and sent to their respective laboratories.

Special sampling techniques were used to collect water samples for analysis of chlorofluorocarbons (CFCs) (CFC-12, dichlorodifluoromethane, $\mathrm{CF}_{2} \mathrm{Cl}_{2}$; $\mathrm{CFC}-11$, trichlorofluoromethane, $\mathrm{CFCl}_{3}$; and $\mathrm{CFC}-113$, trichlorotrifluoroethane, $\mathrm{C}_{2} \mathrm{~F}_{3} \mathrm{Cl}_{3}$ ), sulfur hexafluoride $\left(\mathrm{SF}_{6}\right)$, dissolved gases (argon, carbon dioxide, methane, nitrogen, and oxygen), tritium/ helium $\left({ }^{3} \mathrm{H} /{ }^{3} \mathrm{He}\right)$, and ${ }^{14} \mathrm{C}$. These techniques were used to ensure that ground-water samples did not come in contact with the atmosphere (U.S. Geological Survey, 2005a). Accuracy of CFC dating was improved with sequential collection of dissolved-gases samples in serum bottles. Analyses of these dissolved-gases samples can be used to help define recharge temperatures used to calculate ground-water ages (Busenberg and Plummer, 1992). Samples collected for analysis of ${ }^{3} \mathrm{H} /{ }^{3} \mathrm{He}$ were sealed in copper tubing to prevent atmospheric contact (U.S. Geological Survey, 2005b). Samples collected for analysis of ${ }^{14} \mathrm{C}$ and carbon-13/carbon- $12\left({ }^{13} \mathrm{C} /{ }^{12} \mathrm{C}\right)$ were collected in capped, 1-L serum bottles and sent to the Environmental Isotope Laboratory in Waterloo, Ontario, Canada (discussed in next section). 


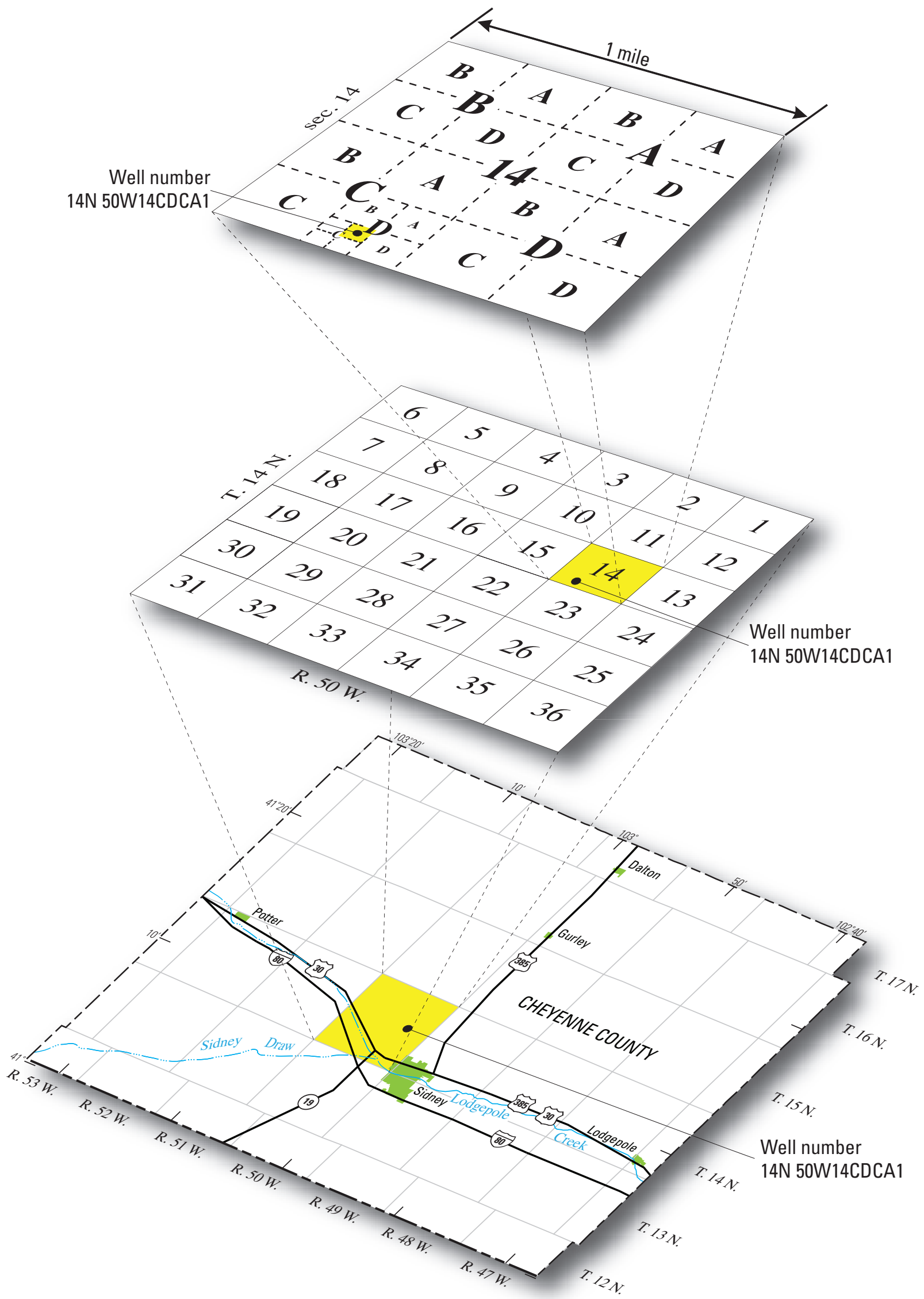

Figure 6. Local well-numbering system. 
During the times when samples were collected from the monitoring-well network, excluding small flows downstream from the water-treatment facility in Sidney, flows were insufficient (water typically was ponded and stagnant) or nonexistent. As a result, no surface-water samples were collected for this study.

\section{Sample Analysis}

Water samples from all sites were analyzed for physical characteristics (specific conductance, $\mathrm{pH}$, temperature, and dissolved oxygen), major ions (calcium, magnesium, sodium, potassium, sulfate, and chloride), nutrients [such as nitrate as nitrogen $(\mathrm{N})$ ], selected trace elements (aluminum, arsenic, boron, fluoride, iron, manganese, silica, and strontium), and stable isotopes of water [deuterium/protium $\left({ }^{2} \mathrm{H} /{ }^{1} \mathrm{H}\right)$ and oxygen-18/oxygen-16 $\left.\left({ }^{18} \mathrm{O} /{ }^{16} \mathrm{O}\right)\right]$. In addition, a sample subset was analyzed for any combination of $\mathrm{CFCs}$, dissolved gases, tritium $\left({ }^{3} \mathrm{H}\right),{ }^{3} \mathrm{H} /{ }^{3} \mathrm{He}, \mathrm{SF}_{6}$, and carbon isotopes ${ }^{13} \mathrm{C} /{ }^{12} \mathrm{C}$ and ${ }^{14} \mathrm{C}$.

Conventional nomenclature is used in this report to present results of isotopic analysis. Stable isotopes of low-mass (light) elements such as oxygen, hydrogen, and carbon commonly are reported using " $\delta$ " (delta) values, which indicate parts per thousand or per mil. The general expression for $\delta$ calculation uses the equation (Kendall and Caldwell, 1998):

where

$$
\delta(\text { in per mil })=\left[\frac{R_{\mathrm{x}}}{R_{\mathrm{s}}}-1\right] \bullet 1,000,
$$

$$
\begin{aligned}
& R_{\mathrm{x}} \quad \begin{array}{l}
\text { is the ratio of the heavy to light isotope of the } \\
\text { sample; and }
\end{array} \\
& R_{\mathrm{s}} \quad \text { is the ratio of the heavy to light isotope of the } \\
& \text { standard (for example }{ }^{2} \mathrm{H} /{ }^{1} \mathrm{H} \text { ). }
\end{aligned}
$$

A negative $\delta$ value indicates that the sample is depleted of the heavy isotope relative to the standard or that the sample is isotopically "light" (Coplen and others, 2000).

Isotopic fractionation is a process by which isotopic compounds are altered by chemical, biological, or physical processes. This process partitions isotopes and is a function of the differences in the masses of the isotopes. In general, isotopic fractionation occurs as a result of equilibrium or kinetic isotope reactions within physical or chemical processes (Coplen and others, 2000).

Because the heavier isotope has a stronger molecular bond $\left({ }^{2} \mathrm{H}\right.$ has a stronger molecular bond than ${ }^{1} \mathrm{H}$, and ${ }^{18} \mathrm{O}$ has a stronger molecular bond than ${ }^{16} \mathrm{O}$ ), the liquid phase of water generally is "heavier" than the gaseous phase (Kendall and Caldwell, 1998). The lighter isotope is more reactive than the heavier isotope (Coplen, 1993). As a result, evaporation is a major fractionation process in which the lighter isotope is concentrated in the product (water vapor), whereas the heavier isotope enriches the reactant (the aqueous phase).

Water samples collected for major ion and nutrient analyses were sent to the USGS National Water Quality Laboratory (NWQL) in Denver, Colorado. Methods for analytical procedures used by the NWQL can be found on the World Wide Web at http://nwql.usgs.gov/Public/ref_list.htm . Water samples collected for CFC, dissolved gases, and $\mathrm{SF}_{6}$ analyses were sent to the USGS Reston Chlorofluorocarbon Laboratory in Reston, Virginia (http://water.usgs.gov/lab/cfc). Methods for analytical procedures used by the USGS Reston Chlorofluorocarbon Laboratory are described in Busenberg and Plummer (1992), Busenberg and others (1998), and Busenberg and Plummer (2000) or references therein. Water samples collected for ${ }^{2} \mathrm{H}$ and ${ }^{18} \mathrm{O}$ analyses were sent to the USGS Reston Stable Isotope Laboratory in Reston, Virginia. Methods for analytical procedures used by the USGS Reston Stable Isotope Laboratory can be found on the World Wide Web at http://isotopes.usgs.gov/publications.htm. Water samples collected for ${ }^{3} \mathrm{H}$ analysis (Thatcher and others, 1977) were sent to the USGS Isotope Tracers Project laboratory in Menlo Park, California. Water samples collected for ${ }^{3} \mathrm{H} /{ }^{3} \mathrm{He}$ analysis were sent to Lamont-Doherty Earth Observatory (LDEO) of Columbia University in Palisades, New York. Analytical methods used by LDEO can be found at http://www.ldeo.columbia. edu/ etg/ms_ms/Ludin_et_al_MS_Paper.htm . Water samples collected for ${ }^{14} \mathrm{C}$ and ${ }^{13} \mathrm{C}$ analyses were sent to the Environmental Isotope Laboratory in Waterloo, Ontario, Canada. Methods for analytical procedures for the analysis of water samples for ${ }^{14} \mathrm{C}$ and ${ }^{13} \mathrm{C}$ are described by Stuiver and Polach (1977) and McCrea (1950), respectively.

\section{Data-Analysis Procedures}

Data-analysis procedures included general statistical analysis and construction of boxplots, trilinear diagrams, scatter plots, and time-series plots. This report contains only selected plots necessary to support the discussion. Some data are described in terms of statistical quartiles (percentiles), which are data values less than 25, 50 (median), or 75 percent of the sample observations. Percentiles are more descriptive than the minimum and maximum because they are resistant to influence from outliers and more accurately describe the distribution of the data (Helsel and Hirsch, 1992). In addition, percentiles (nonparametric methods) are preferred because water-quality data often are censored, non-normally distributed, and sample sizes are small such that non-normality is difficult to detect.

Two nonparametric hypothesis tests were used for comparisons of the data-the Mann-Whitney rank-sum test (Helsel and Hirsch, 1992) and the Wilcoxon signed-rank test for large sample sets (more than 15 samples) (Dowdy and Wearden, 1991; Helsel and Hirsch, 1992). The Mann-Whitney rank-sum test was used to determine if median chemical concentrations were significantly different for independent populations (for example, comparison of nitrate concentrations in samples from the Ogallala aquifer compared to those from the Brule sand aquifer). The Wilcoxon signed-rank test was used to determine if paired chemical concentrations were significantly different (for example, comparison of samples collected from the same 
sites but on separate days). All statistical analyses used a significance level of 95 percent $(\alpha=0.05)$. A significance level is the probability that the test statistic generated for that test accurately defines the populations being tested. The p-value associated with a particular test result is the probability of obtaining a test statistic equal to, or more extreme than, the value computed from the data when the null hypothesis (difference in the medians of the two populations is zero) is true. Simpler put, p-values that are 0.05 or smaller indicate that a significant difference between the medians of the two populations can be inferred with 95-percent confidence. That is, the smaller the p-value, the greater the confidence in the difference between the two populations.

Nonparametric statistical methods rely on data ranks rather than actual data values and do not require that data follow any specific probability distribution (Dowdy and Wearden, 1991). For nonparametric statistical analysis, censored data were categorically grouped and were assigned a value equal to one-half the laboratory reporting level. Because the tests performed are nonparametric and compare two independent populations by ranking the data, assigning a minimum value to the censored data did not affect the hypothesis-test results (Helsel and Hirsch, 1992).

\section{Age Dating of Ground Water}

Recharge of ground water as long ago as the 1940s can be determined with relatively accurate methods of age dating. These methods, some of which are discussed in the following paragraphs, have helped scientists and water managers determine the relation between the history of land use and groundwater contamination.

\section{Chlorofluorocarbons and Sulfur Hexafluoride}

CFCs are stable, synthetic, halogenated alkanes that now can be used for age dating of ground water (Plummer and Busenberg, 2000). CFCs, used as aerosol propellants, cleaning agents, solvents, and blowing agents in the production of foam rubber and plastics, eventually get released into the atmosphere and subsequently get transported into the hydrosphere (Plummer and Busenberg, 2000). Until the early to mid-1990s, CFC concentrations in the atmosphere had increased at a nearly linear rate (fig. 7) since CFCs were first produced as safe refrigerants in the 1930s. Consequently, precipitation that fell to the earth since the mid-1940s has a unique CFC signature. The age of relatively young ground water (less than 50 years old) can be determined by analyzing water samples for CFCs.

CFC concentrations in the water samples were compared to calculated and measured values in the air (fig. 7). The CFC age-dating technique is more precise, and analytical costs are less than other techniques, such as ${ }^{3} \mathrm{H}$, for dating recently recharged ground water. Previous studies using the CFC technique have determined the age of recently recharged ground water with an accuracy of plus-or-minus 1 to 3 years
(Busenberg and Plummer, 1992). CFC ground-water ages also agree favorably with ages determined using other dating techniques such as ${ }^{3} \mathrm{H},{ }^{3} \mathrm{H} /{ }^{3} \mathrm{He}$, and krypton-85 (Ekwurzel and others, 1994). However, over time CFCs can and do degrade under certain geochemical conditions (for example, reducing conditions). Therefore, the overall accuracy of ground-water age dating by CFCs also can diminish and should be evaluated using dissolved gases data. Further discussion on the uses and limitations of CFCs for age-dating purposes can be found in Cook and Solomon (1995), Szabo and others (1996), Clark and Fritz (1997), Solomon and others (1998), and Plummer and Busenberg (2000) and references therein.

$\mathrm{SF}_{6}$ can occur naturally, but it is primarily anthropogenic in origin. In the 1960s, substantial production of $\mathrm{SF}_{6}$ began for use in high-voltage electrical switches (Plummer and Busenberg, 2000). Similar to $\mathrm{CFCs}_{2} \mathrm{SF}_{6}$ in the atmosphere and precipitation imparts a specific signature. However, unlike $\mathrm{CFCs}, \mathrm{SF}_{6}$ apparently is stable in reducing ground-water environments, and uncertainties associated with use of $\mathrm{SF}_{6}$ as an age-dating tool are fewer. In addition, $\mathrm{SF}_{6}$ mixing ratios are small [about 4 parts per trillion volume (pptv)], and age dating of ground water is possible to about 1970 (Plummer and Busenberg, 2000). $\mathrm{SF}_{6}$ has an estimated atmospheric lifetime of 800 (Morris and others, 1995) to 3,200 years (Ravishankara and others, 1993), and atmospheric concentrations are expected to increase (Busenberg and Plummer, 1997). Therefore, $\mathrm{SF}_{6}$ is expected to continue to be a useful ground-water age-dating tool for post-1990s ground water.

Because uncertainties in CFC ages can arise from factors such as thickness of unsaturated zone, mixture of young and old water, CFC degradation, and errors in estimating the recharge temperature, all results of the $\mathrm{CFC}$ analyses were examined using three flow or mixing scenarios-piston flow (water moving as a slug), binary mixing (old water mixed with young water), and exponential mixing (infinite number of inputs, such as a well with a long screened interval). Sensitivity and flow-characteristic analyses were facilitated using a spreadsheet (Julian Wayland, U.S. Geological Survey, written commun., 2005).

\section{Tritium, Tritium/Helium, Carbon-14}

Tritium is a naturally occurring radioactive isotope of hydrogen with a half-life of 4,500 days (12.32 years) (Lucas and Unterweger, 2000). Most of the ${ }^{3} \mathrm{H}$ present in the atmosphere prior to thermonuclear testing in the 1950s and 1960s was the result of natural production in the upper atmospherebombardment of nitrogen by neutrons in cosmic radiation (Solomon and Cook, 2000).

Tritium is used to date young ground water because of its short half-life (Mann and others, 1982). The natural background activity of ${ }^{3} \mathrm{H}$ in precipitation prior to 1952 was about 1 to $10 \mathrm{TU}$ (Davis and DeWiest, 1966) with each TU equal to one ${ }^{3} \mathrm{H}$ atom in $10^{18}$ atoms of hydrogen. Beginning in 1952, large amounts of ${ }^{3} \mathrm{H}$ were added to this natural background value from above-ground testing of thermonuclear devices. 


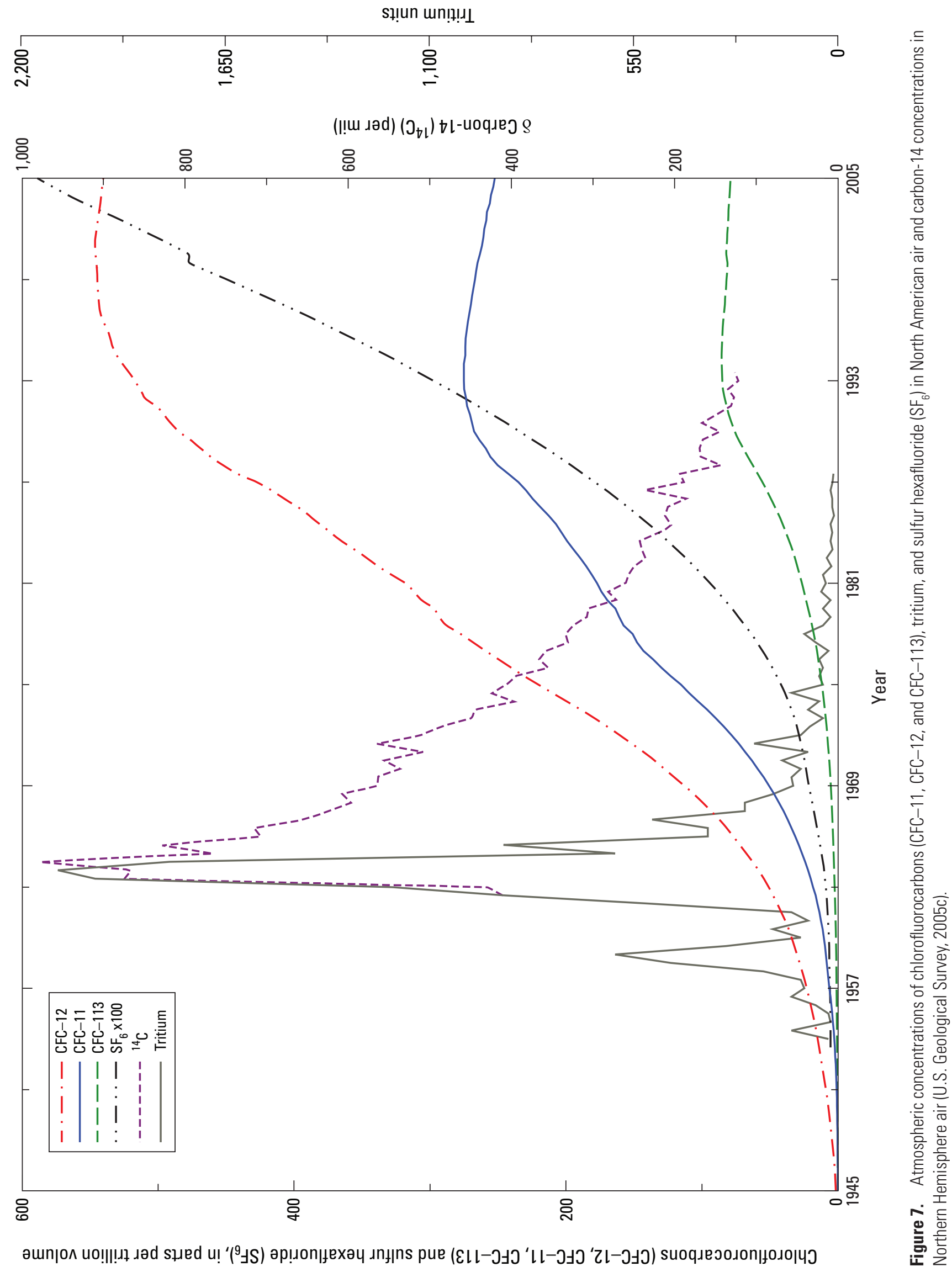


Concentrations of ${ }^{3} \mathrm{H}$ in precipitation have been monitored at numerous locations throughout North America since the early 1950s. Ottawa, Ontario, Canada (not shown in figures) has a fairly complete record of ${ }^{3} \mathrm{H}$ concentrations in North American precipitation from 1953 to the present (fig. 7). At the 1963 peak, the production of human-generated ${ }^{3} \mathrm{H}$ was 100 to 1,000 times greater than that of natural ${ }^{3} \mathrm{H}$ production (Fontes, 1980). Since that time, ${ }^{3} \mathrm{H}$ concentrations in Ottawa precipitation have decreased gradually to about $20 \mathrm{TU}$ (International Atomic Energy Agency, 1992).

Because of its half-life, ${ }^{3} \mathrm{H}$ can be used as a natural tracer. However, because the ${ }^{3} \mathrm{H}$ input varied seasonally and from year to year, and the peak input was in the early 1960s, age dating with ${ }^{3} \mathrm{H}$ is not as precise as the other methods used in this study. Assuming that pre-1950s ${ }^{3} \mathrm{H}$ concentrations in ground water were no greater than 6 to $7 \mathrm{TU}$ (Solomon and Cook, 2000), water samples with ${ }^{3} \mathrm{H}$ concentrations greater than $0.5 \mathrm{TU}$ (in 2004) generally represent water that has recharged after the peak of the thermonuclear-device testing of 1963. Water samples with ${ }^{3} \mathrm{H}$ concentrations less than $0.5 \mathrm{TU}$ (in 2004) generally represent water recharged prior to 1963 . Moreover, water samples with ${ }^{3} \mathrm{H}$ concentrations that were not measurable (in 2004) likely recharged prior to the early 1950s. One of the primary problems with using ${ }^{3} \mathrm{H}$ for age dating is that for water that was recharged after the 1963 peak, the graph of measured concentrations in Northern Hemisphere precipitation (fig. 7) shows that concentrations are too variable to accurately determine an apparent age. In other words, ${ }^{3} \mathrm{H}$ concentrations are not a linear function of time; there are too many points on the time line that could correspond to the same concentration of ${ }^{3} \mathrm{H}$ and thus to the age that a sample represents.

Another method of age dating with ${ }^{3} \mathrm{H}$ is to associate its decay relative to production of ${ }^{3} \mathrm{He}$. Tritium can decay to ${ }^{3} \mathrm{He}$ when isolated from the atmosphere. Because the decay rate is constant, ${ }^{3} \mathrm{H} /{ }^{3} \mathrm{He}$ can be measured to determine the age of the water. Most ${ }^{3} \mathrm{H} /{ }^{\beta} \mathrm{He}$ is a product of thermonuclear-device testing in the mid- to late $1950 \mathrm{~s}$, but some terrigenous-derived ${ }^{3} \mathrm{He}$ also occurs. Therefore, concentrations of the terrigenous ${ }^{3} \mathrm{He}$ need to be adjusted and accounted for. The tritiogenic ${ }^{3} \mathrm{He}^{*}$ (* is used to indicate tritiogenic ${ }^{3} \mathrm{He}^{*}$ ) is used to distinguish ${ }^{3} \mathrm{He}$ produced from the decay of ${ }^{3} \mathrm{H}$ from that produced from other sources (Solomon and others, 1998). Details on the uses and limitations of ${ }^{3} \mathrm{H} /{ }^{3} \mathrm{He}$ age dating of ground water can be found in Solomon and others (1998) and Solomon and Cook (2000) and references therein.

Measurements of ${ }^{14} \mathrm{C}$ concentrations in ground water are useful for dating ground water with long residence times (greater than 50 years). Radiocarbon age dating with ${ }^{14} \mathrm{C}$ cannot be done on the water molecule itself but is done on the dissolved organic or inorganic carbon in water (Clark and Fritz, 1997). The half-life of ${ }^{14} \mathrm{C}$ (5,730 years) and the ubiquity of carbon make it an ideal tracer to date ground water that can be 1,000 s to 10,000 s of years old (Kalin, 2000). Prior to the thermonuclear device tests mentioned previously, atmospheric composition of ${ }^{14} \mathrm{C}$ presumably was relatively constant $\left(A_{\mathrm{o}}\right)$ and is referred to as $100 \mathrm{pmC}$ (Parkhurst and Plummer, 1993). For this study, an assumption was made that decay was the only process decreasing the amount of ${ }^{14} \mathrm{C}$ in ground water. Dates derived from ${ }^{14} \mathrm{C}$ radiocarbon age-dating analyses generally are on the order of 100s to 10,000s of years. Therefore, results are reported in years before present (ybp).

The ${ }^{14} \mathrm{C}$ isotope fractionates during the organic or inorganic phase transformation. To maintain universality for dating purposes, ${ }^{14} \mathrm{C}$ activity was normalized to the international standard for contemporary carbon (NIST Oxalic Acid SRM 4990-C) (Kalin, 2000)—normalized to a common $\delta^{13} \mathrm{C}$ value (-25 per mil) (Clark and Fritz, 1997). Therefore, water samples also were analyzed for ${ }^{13} \mathrm{C} /{ }^{12} \mathrm{C}$ to determine the $\delta^{13} \mathrm{C}$ value of the sample reported as $\delta^{13} \mathrm{C}$ [in per mil content of the Vienna Peedee belemnite (PDB) or the standard for computation of ${ }^{13} \mathrm{C}$ (Bullen and Kendall, 1998)]. Further discussion on normalization of $\delta^{13} \mathrm{C}$ can be found in Clark and Fritz (1997) and Kalin (2000).

The age of the water was determined by the following equation (modified from Parkhurst and Plummer, 1993):

$$
t=\frac{5,730}{\ln (2)} \ln \left(\frac{A_{O}}{A}\right),
$$

where

$t \quad$ is the estimated age of the ground water, in years;

$$
\begin{gathered}
5,730 \quad \text { is the half-life of }{ }^{14} \mathrm{C} \text {, in years; } \\
A_{o} \quad \text { is the starting concentration of }{ }^{14} \mathrm{C} \text { in the } \\
A \quad \text { water; and } \\
\text { is the concentration of }{ }^{14} \mathrm{C} \text { in the sample. }
\end{gathered}
$$

The apparent age of water using ${ }^{14} \mathrm{C}$ was determined using the computer program NETPATH (Plummer and others, 1994). To estimate $A_{\mathrm{o}}$, several models—some more complex than others-are available in NETPATH. The Fontes and Garnier (1979) model assumes a "two-stage evolution of the recharge water accounting for dissolution and isotopic exchange of $\mathrm{CO}_{2}$ [carbon dioxide] in the unsaturated zone and isotopic exchange with carbonate rocks in the saturated zone" (Plummer and others, 1994, p. 28). This model generally agreed with some of the other complex models available in NETPATH and was chosen to estimate $A_{\mathrm{o}}$ for radiocarbon age dating of ground water. For this report, the Fontes and Garnier (1979) model was selected with the option of an open system (gas-solution equilibrium).

Like ${ }^{3} \mathrm{H} /{ }^{3} \mathrm{He}$ age dating, age dating with ${ }^{14} \mathrm{C}$ is too complex to be sufficiently described in this report. Details on the use and limitations of ${ }^{14} \mathrm{C}$ in dating of ground water can be found in Bullen and Kendall (1998), Wang and others (1998), and Kalin (2000) and references therein.

\section{Hydrogen and Oxygen Isotopes}

Hydrogen $(\mathrm{H})$ and oxygen $(\mathrm{O})$, respectively, are the third and first most abundant elements on the surface of the Earth (Coplen and others, 2002) and are isotopically covariant. In general, the ratio of the two most common isotopes of $\mathrm{H}$ and 
$\mathrm{O}$ in terrestrial water varies within the environment by a factor of 2 and 5 percent, respectively (Coplen and Kendall, 2000). Coplen and others (2000) reported that these large variations are seasonally and climatically induced, which allow hydrologists to identify and quantify the source of water. Relative to precipitation during warm seasons, precipitation during cold seasons is depleted in ${ }^{2} \mathrm{H}$ and ${ }^{18} \mathrm{O}$ (Coplen and others, 2002). Furthermore, chemical analysis of the $\mathrm{H}$ and $\mathrm{O}$ isotopes provides information about the water molecules directly instead of using physical inferences, such as water-level data and hydraulic conductivity of the aquifer.

Water samples collected for analyses of $\delta^{2} \mathrm{H}$ and $\delta^{18} \mathrm{O}$ are compared relative to the Vienna Standard Mean Oceanic Water (VSMOW). Using this standard, Craig (1961) found that for freshwater, precipitation worldwide could be expressed using the slope of the global meteoric waterline (GMWL) $\left(\delta^{2} \mathrm{H}=\right.$ $\left.8 \delta^{18} \mathrm{O}+10\right)$. Together with the GMWL, this report uses two local meteoric waterlines (LMWL) established by Harvey and Welker (2000) and Harvey (2005) from analysis of precipitation samples collected at North Platte, Nebraska, and the Pawnee National Grassland in Colorado (fig. 1). Harvey and Welker (2000) reported that the slope for the LMWL at North Platte was $\delta^{2} \mathrm{H}=7.66 \delta^{18} \mathrm{O}+4.96\left(\mathrm{R}^{2}=0.97\right)$, and Harvey (2005) reported that the slope for the LMWL at the Pawnee National Grassland was $\delta^{2} \mathrm{H}=7.86 \delta^{18} \mathrm{O}+7.7\left(\mathrm{R}^{2}=0.991\right)$. Although both LMWLs are from samples collected at locations distant from the study area (about 115 mi east of the study area for North Platte and about 96 mi west of the study area for Pawnee National Grassland), these LMWLs are thought to adequately represent the study area.

\section{Creation of Water-Table Map and Cross Sections}

The hydrogeologic sections (fig. 4) were created using historical data and data collected during the study. The hydrogeologic sections were created using data (lithologic logs and borehole geophysical $\log$ ) obtained during installation of the monitoring wells. The water-table map (fig. 8) was created from a synoptic water-level survey of areally distributed irrigation and monitoring wells conducted March 2005. Results of this water-level survey are present in table 4 in the Appendix at the back of this report. Where wells were not available for measurement of water levels, water levels were inferred using previous studies, historical maps, or historical measurements. The time for survey (March 2005) was selected because spring is prior to the beginning of irrigation season (May to September) and close to when ground-water levels were expected to be at their highest following the previous irrigation season. In addition, this time was about 1 month before water-quality sample collection in April 2005.

\section{Quality Assurance and Quality Control}

This section describes the quality-assurance (QA) and QC measures that were used to ensure that the collection, processing, and analysis of the water samples were of a known and acceptable quality. For the readers convenience, this section also describes the QA and QC results.

Prior to the collection of the data, QA objectives for accuracy, precision, completeness, and representativeness were assembled from the USGS Nebraska Water Science Center QA Plan (U.S. Geological Survey, written commun., 2004) and from additional objectives developed for this study. The QA objectives included minimum acceptable standards for all field and laboratory data. Data for particular analyses that did not meet these QA objectives were still reported in the data tables in the Appendix of this report but were flagged accordingly and noted in the text. QA procedures also included participation by USGS personnel in the National Field Quality-Assurance Tests administered annually by the USGS (Erdmann and Thomas, 1985, p. 110-115).

The accuracy of field and laboratory analytical data was determined using several types of QC samples. Field-data accuracy was evaluated by collection and analysis of replicate and field-blank samples. Eight replicate and four field-blank samples (about 17 percent of the total samples) were collected during the study. An initial equipment blank was collected and processed at the South Platte NRD office to determine the effectiveness of decontamination procedures. Following collection of this initial equipment-blank sample, remaining QC samples were collected sequentially with the environmental samples and then were processed and shipped. Field blanks were collected onsite prior to collection of environmental samples. Replicate samples were collected and processed using a new filter following collection of the environmental sample. Field equipment was cleaned and decontaminated immediately after collection of the blank sample or immediately before collection of the replicate sample. Replicate samples were used to assess overall sampling variability. The accuracy of laboratory analytical data was evaluated using standard methods and submittal of blind-reference samples to the NWQL by the USGS Branch of Quality Assurance (U.S. Geological Survey, 2006b). In addition, major-ion samples were reanalyzed by the NWQL if ion balance was not within 5 percent.

QC samples indicated ground-water environmental samples typically were similar to replicate samples. Of 156 replicate analyses for the eight pairs of samples, the median variance between the environmental and the replicate concentrations was 0 percent, and the mean was -0.09 percent. Two environmental ground-water samples collected and analyzed for acid neutralizing capacity varied by 27 and 14 percent (140 to 102 and 253 to $289 \mathrm{mg} / \mathrm{L}$, respectively). The reason for the large variances between samples is unknown, but the authors speculate that degassing may have occurred during the 


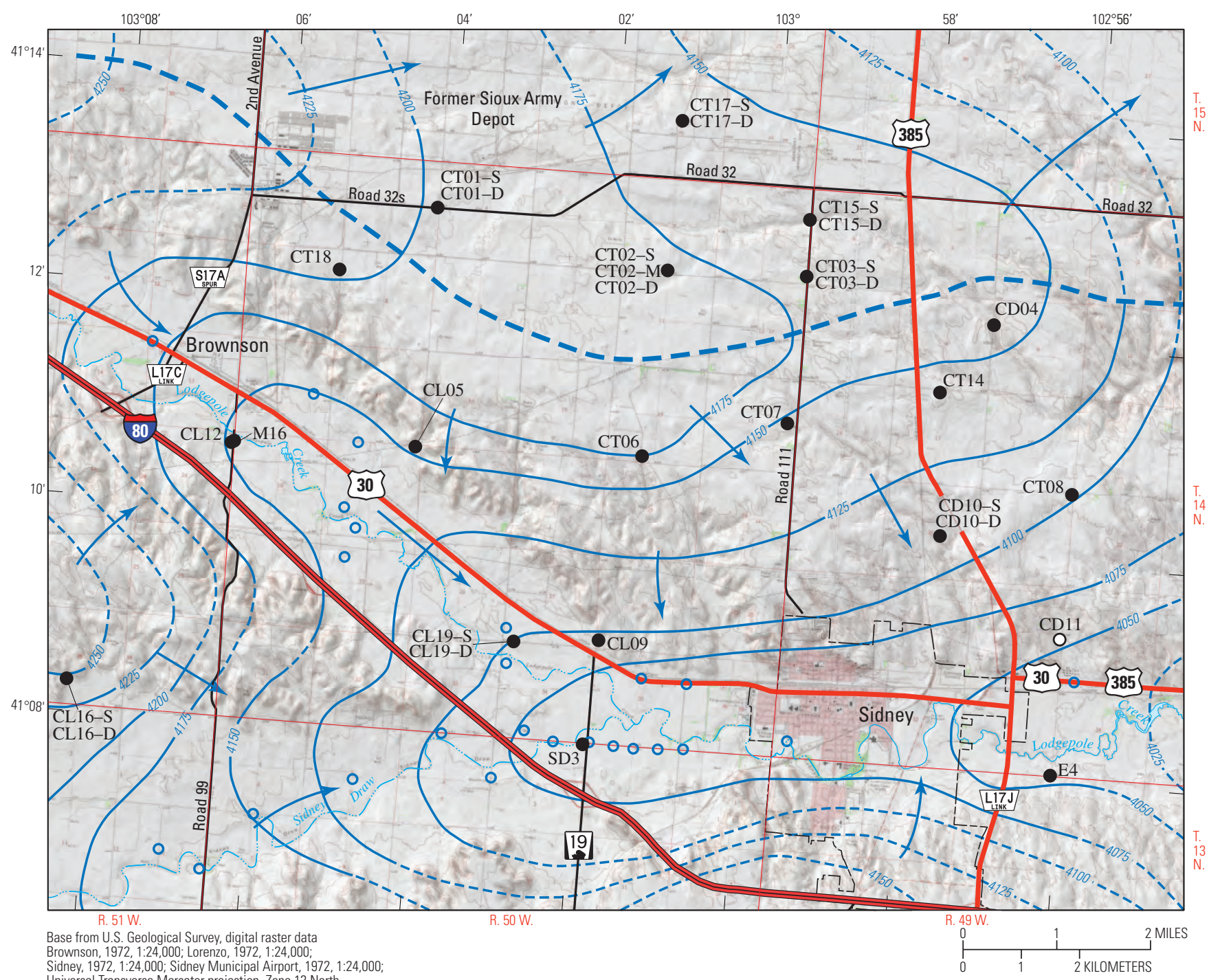

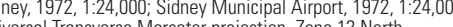

Horizontal coordinate information is referenced to the North American Datum of 1983 (NAD 83)

EXPLANATION

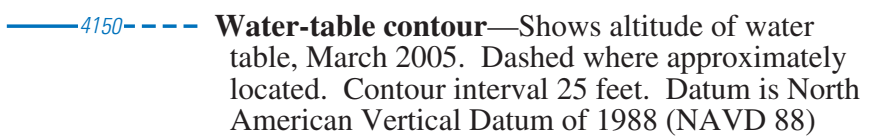

- - - - Approximate location of ground-water divide

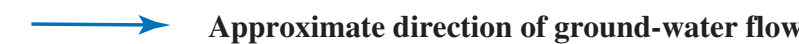

\section{○ Water-table measurement point}

CT02-S

CT02-M

Monitoring-well location and identifier $-S$ indicates well-screen interval was shallow. M indicates wellscreen interval was at medium depth. D indicates wellscreen interval was deep

CD11 $\mathrm{O}$ Test-hole location and identifier

Figure 8. Generalized configuration of water table in study area, March 2005, and approximate direction of ground-water flow.

time between sample collection and analysis. Another environmental ground-water sample collected and analyzed for orthophosphate varied by about 10 percent $(0.067$ to $0.074 \mathrm{mg} / \mathrm{L})$. Other than these samples, the largest relative percentage differences in QC replicate samples were 8.6 percent or less-139 to $151 \mathrm{mg} / \mathrm{L}$ for alkalinity (-8.6 percent), 0.153 to $0.141 \mathrm{mg} / \mathrm{L}$ for orthophosphate (-7.8 percent), 1.4 to $1.3 \mathrm{mg} / \mathrm{L}$ for fluoride (7.1 percent), 63 to $68 \mu \mathrm{g} / \mathrm{L}$ for boron (-7.9 percent), 1.5 to $1.4 \mu \mathrm{g} / \mathrm{L}$ for manganese (6.7 percent), and 0.019 to 0.018 for nitrite as nitrogen (5.3 percent). All concentrations in other replicate ground-water samples were less than 5 percent of those in the environmental samples.

QC samples collected to evaluate decontamination techniques (Wilde, 2004) indicated that the blank samples were generally free of contamination, although trace concentrations of calcium, magnesium, and silicate were found [all less than $0.5 \mathrm{mg} / \mathrm{L}$, except for silica in one sample $(1.57 \mathrm{mg} / \mathrm{L})]$. No direct explanation could be made about the contamination source for these trace detections; however, prior to the study the South Platte NRD submersible pump used for the sample 
collection had not previously been decontaminated using procedures similar to those used during this study.

\section{Evaluation of Ground Water}

This section describes the results of the evaluation of ground water for Sidney, Nebraska, using the water-level measurements made in March 2005 and water-quality analyses of ground-water samples collected during April 2004 and April 2005. Ground-water results are discussed with respect to physical characteristics such as $\mathrm{pH}$ and temperature. The discussion of physical characteristics focuses on the median concentrations or other measures but also compares quartiles with respect to the aquifer (Ogallala, Brule, and Brule sand) or well location (Lodgepole Creek Valley, tableland areas, and tableland draws). The chemical characteristics of the water are similarly discussed, and the results of ground-water age dating and sample analyses for $\delta^{18} \mathrm{O}$ and $\delta^{2} \mathrm{H}$ are presented. It is important to restate an important caveat in that this report discusses the Brule in terms of an "aquifer." In some cases, especially in the tableland areas, the Brule represents a confining unit. However, because the authors were unable to identify secondary permeability features in the Brule during the test-hole drilling for the monitoring wells and many of the Brule monitoring wells in the tableland areas produced similar volumes as those in Lodgepole Creek Valley, no attempt was made to differentiate the Brule monitoring wells with respect to being fractured or unfractured. The authors did look at variances in ground-water quality between wells in the tableland areas and those in Lodgepole Creek Valley.

Most water-quality data collected during this study are presented in tabular form in the Appendix (tables 5, 6, and 7). However, data not presented in this report (such as concentrations of nitrite as nitrogen) can be found on the Web at http://waterdata.usgs.gov/ne/nwis/qw.

\section{Ground-Water Availability}

Ground water appears to be limited in extent in the tableland areas. Locally within the tableland areas, ground water occurred only at the Ogallala-Brule contact. In these areas, recharging water percolates through the unsaturated zone until it reaches the Brule, which is hydraulically much less permeable than the overlying Ogallala. Once the water encounters the Brule, it either recharges areas of the aquifer where the saturated zone is thin or the ground water laterally migrates towards aquifers of limited extent. In the tableland areas during spring 2005, depths to ground water generally ranged from about 95 to $188 \mathrm{ft}$ (table 4 in the Appendix).

In the tableland draws, ground water was limited to the contacts between the Ogallala and the Brule. This indicates that much of the ground water that moves from the tableland areas to Lodgepole Creek though the tableland draws moves along the contact of the Ogallala and Brule. However, because just three wells were installed in the tableland draw areas, quantitative movement of ground water from the tableland areas to Lodgepole Creek Valley could not be assessed. During spring 2005 depths to ground water in the tableland draw areas were measured at about 42 and $62 \mathrm{ft}$ (table 4).

In Lodgepole Creek Valley, ground water was prevalent during the sampled periods. However, during the course of the study, precipitation was marginal, and no surficial flows were observed. Ground water in Lodgepole Creek Valley generally ranged in depth from near land surface (near Lodgepole Creek) to $91 \mathrm{ft}$ (table 4) adjacent to the valley walls.

The approximate direction of ground-water flow in much of the study area for March 2005 was from areas of recharge to the north and west toward Lodgepole Creek (fig. 8). A ground-water divide controls the ground-water flow in the tableland areas north of Sidney (fig. 8). Ground water north of the divide predominantly flows northeasterly toward the North Platte Valley and its tributaries, whereas immediately south of the divide, ground water flows predominantly in a southeasterly direction toward Lodgepole Creek. Ground water in Lodgepole Creek Valley flows toward Lodgepole Creek, where it generally flows toward or parallel to the creek. During times of plentiful precipitation and little to no irrigation, ground water occasionally discharges into Lodgepole Creek. Along the general axis of Lodgepole Creek Valley, hydraulic head decreases about $225 \mathrm{ft}$ within the study area from the west to the east, with a hydraulic gradient of about $0.0029 \mathrm{ft} / \mathrm{ft}$. Flow from the Sidney Draw area enters Lodgepole Creek Valley from the southwest, but this flow is limited much like the flow in the Lodgepole Creek alluvium.

Yields from monitoring wells open to the Brule aquifer in Lodgepole Creek Valley compared to those in the tableland areas were tested to determine significance. Although most irrigation wells in the study area are in Lodgepole Creek Valley, indicating that most of the secondary permeability structures are in the valley too, statistical significance in yields from the monitoring wells could not be inferred ( $\mathrm{p}$-value $=$ $0.1957)$. However, to qualify these results the yields were from the 2-in. diameter submersible pump used for sampling and not from high-volume production pumps.

\section{Water Quality}

\section{Physical Characteristics}

Measurements of specific conductance in water provide an indication of the concentrations of ions in the water (Hem, 1992). Measured values of specific conductance in ground-water samples from the study area ranged from 290 to $2,710 \mu \mathrm{S} / \mathrm{cm}$ (fig. 9A) (table 2) with a standard deviation (or distribution) that ranged from 94 to $550 \mu \mathrm{S} / \mathrm{cm}$. Median specific conductance for ground-water samples from the Brule aquifer was slightly larger $(511 \mu \mathrm{S} / \mathrm{cm})$ than those for either the Brule sand $(446 \mu \mathrm{S} / \mathrm{cm})$ or Ogallala $(405 \mu \mathrm{S} / \mathrm{cm})$ aquifers. Statistical significance in specific conductance values between 


\section{(A) Physical characteristics}

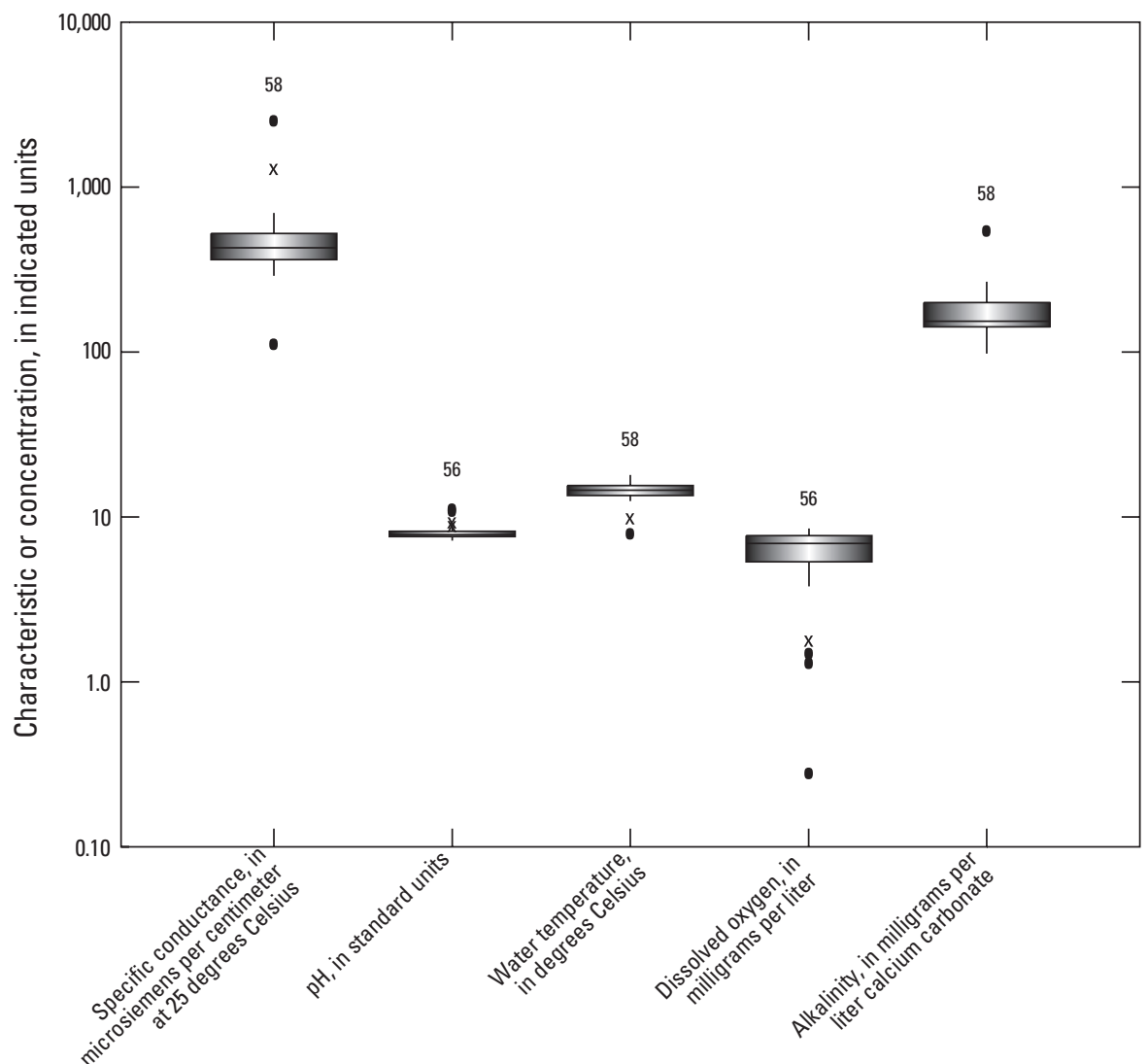

(B) Water-quality constituents

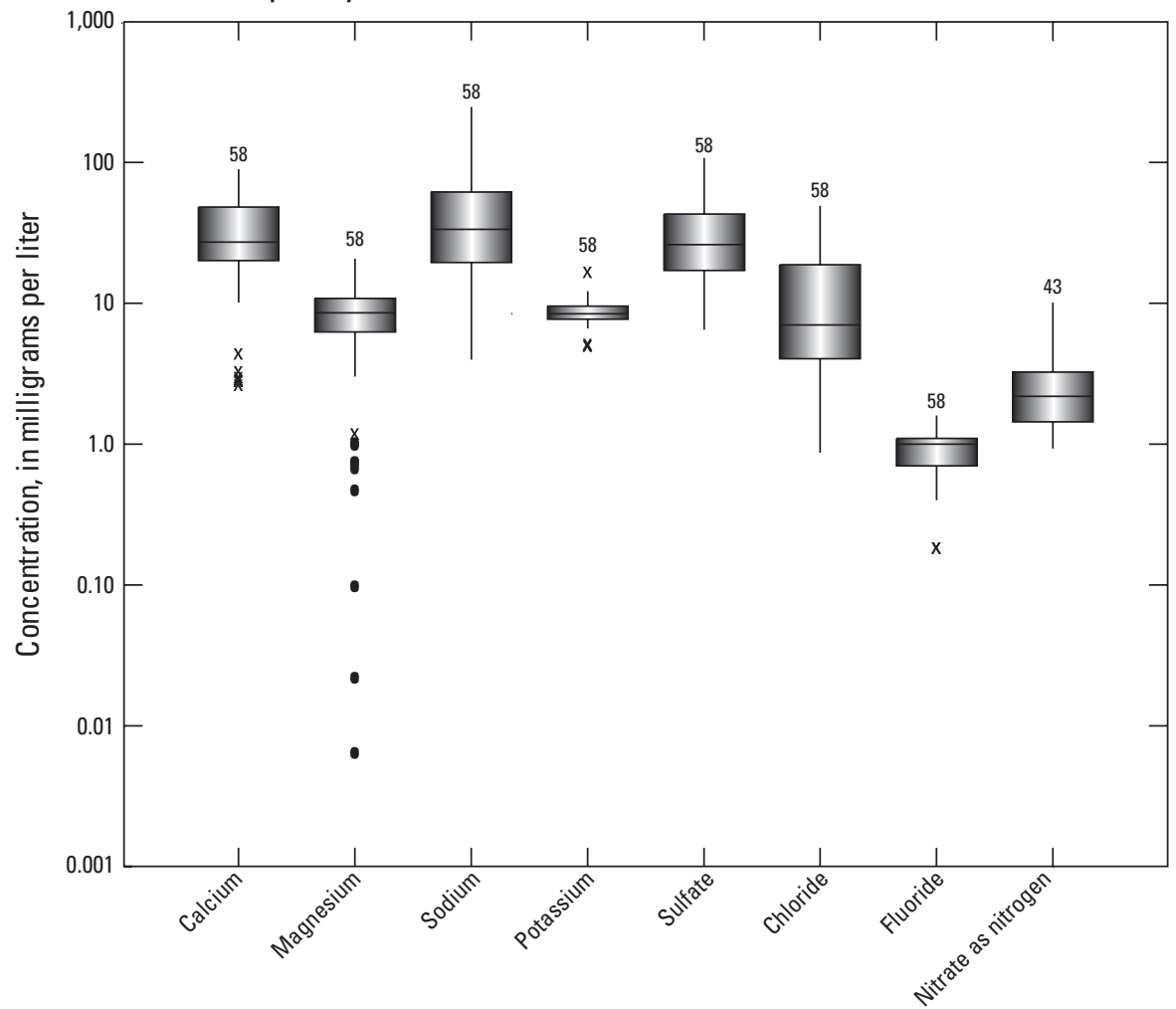

\section{EXPLANATION}

30 - Number of samples

o-Upper detached

x-Upper outside

-Upper adjacent

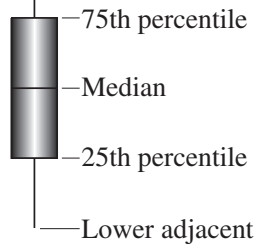

$x$-Lower outside

o-Lower detached

Figure 9. Distribution of (A) physical characteristics and (B) water-quality constituents in study area, 2004-05. 


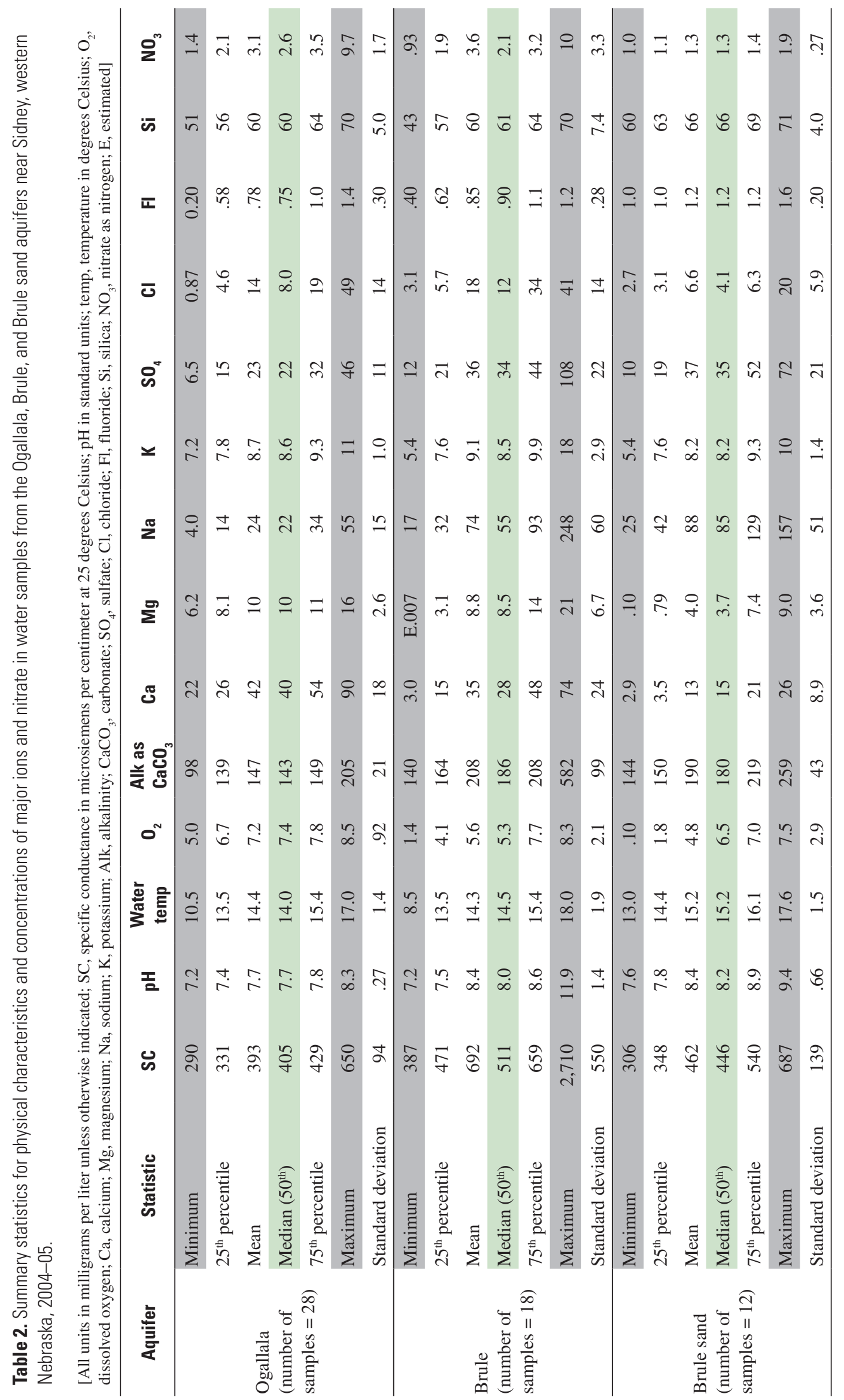


the Ogallala, Brule, or Brule sand aquifers could not be inferred (all p-values greater than 0.05).

Measurements of $\mathrm{pH}$ in ground-water samples from the study area ranged from 7.2 to 11.9 standard units, and water temperatures ranged from 8.5 to $18.0^{\circ} \mathrm{C}$ (fig. 9A) (table 2). The median $\mathrm{pH}$ was 7.7 standard units for the Ogallala aquifer, 8.0 standard units for the Brule aquifer, and 8.2 standard units for the Brule sand aquifer. Median ground-water temperatures varied only slightly $-14.0^{\circ} \mathrm{C}$ (Ogallala), $14.5^{\circ} \mathrm{C}$ (Brule), and $15.2^{\circ} \mathrm{C}$ (Brule sand) (table 2 ).

Measurements of dissolved oxygen in ground-water samples from the study area ranged from 0.1 to $8.5 \mathrm{mg} / \mathrm{L}$, and alkalinity ranged from 98 to $582 \mathrm{mg} / \mathrm{L}$ as $\mathrm{CaCO}_{3}$ (fig. 9A) (table 2). The median dissolved oxygen value was $7.4 \mathrm{mg} / \mathrm{L}$ for the Ogallala aquifer, $5.3 \mathrm{mg} / \mathrm{L}$ for the Brule aquifer, and $6.5 \mathrm{mg} / \mathrm{L}$ for the Brule sand aquifer. Median alkalinity values in ground-water samples varied slightly from the smallest value of $143 \mathrm{mg} / \mathrm{L}$ as $\mathrm{CaCO}_{3}$ in the Ogallala aquifer to nearly equal values of 186 and $180 \mathrm{mg} / \mathrm{L}$ as $\mathrm{CaCO}_{3}$ in the Brule and Brule sand aquifers, respectively (table 2).

\section{Chemical Characteristics}

Overall, the ground-water quality of the study area contained large concentrations of calcium, sodium, and sulfate ions (fig. 9B). Concentrations of these constituents in the ground water ranged from 2.9 to $90 \mathrm{mg} / \mathrm{L}$ for calcium, 4.0 to $248 \mathrm{mg} / \mathrm{L}$ for sodium, and 6.5 to $108 \mathrm{mg} / \mathrm{L}$ for sulfate (fig. $9 B$ ) (table 2). Chloride, which ranged in concentration from 0.87 to $49 \mathrm{mg} / \mathrm{L}$ in ground-water samples, had the largest variation among the anions (fig. 9B).

Water type varied noticeably with respect to aquifer (fig. 10A) and location (fig. 10B). Water samples collected from monitoring wells in the Ogallala were predominantly a calcium bicarbonate type, whereas water samples collected from the Brule were more a sodium bicarbonate type. Water samples collected from monitoring wells open to Brule sand were a mixture of both water types. Water from shallow Brule sand was predominately a calcium bicarbonate type, whereas water from deeper Brule sand was predominately a sodium bicarbonate type. This indicates that the shallower Brule sand has some hydraulic connection with the overlying Ogallala, whereas the deeper sand is more hydraulically isolated. Ground water in Lodgepole Creek Valley and the tableland areas had similar water chemistry_ranging between a calcium bicarbonate to a sodium bicarbonate type (fig. 10B). Most water samples collected from monitoring wells in the tableland draws had a strong calcium signature (fig. 10B), indicating that the Ogallala was the likely source of water for these wells.

Differences among water samples from the Ogallala, Brule, and Brule sand aquifers that were analyzed for calcium, sodium (table 6 in the Appendix), and nitrate (table 5 in the Appendix) ranged from significant to no statistical inference. Significant differences were observed in nitrate concentrations from the Ogallala aquifer compared to the Brule aquifer $(\mathrm{p}$-value $=0.0249)$, and in calcium and nitrate concentrations in water samples from the Ogallala aquifer compared to the Brule sand aquifer ( $\mathrm{p}$-values $=0.0054$ and 0.0168 , respectively) (table 3). Statistical difference in calcium concentrations, however, could not be concluded between water samples collected from the Ogallala aquifer as compared to the Brule aquifer ( $p$-value $=0.0698$ ) or in calcium or nitrate concentrations in water samples collected from the Brule aquifer and the Brule sand aquifer ( $\mathrm{p}$-value $=0.4220$ and 0.3746 , respectively) (table 3). Significant differences in median sodium concentrations were observed in water samples from the Ogallala and Brule (p-values $=0.0062$ ) and in water samples from the Ogallala and Brule sand ( $\mathrm{p}$-value $=0.0165$ ). Whereas differences in sodium concentration between the water samples from the Brule and Brule sand $(p$-value $=0.8991)$ could not be inferred statistically.

Median calcium concentrations were not significantly different in water samples collected from the Ogallala aquifer compared to those collected from the Brule aquifer, but water from the Ogallala had a significantly smaller sodium concentration. These data indicate that ground water in the Ogallala aquifer is chemically isolated for the most part from the Brule sand aquifer but not from the Brule aquifer.

Median concentrations of calcium and sodium from ground-water samples collected from monitoring wells in Lodgepole Creek Valley and compared to the tableland areas could not be distinguished statistically ( $\mathrm{p}$-value greater than 0.05 ) (table 3 ). This indicated that, with respect to location, ground water in Lodgepole Creek Valley was comparable to the tableland areas in concentrations of calcium and sodium. Ground-water samples in Lodgepole Creek Valley had a strong sodium signature that likely resulted from most of the wells being open to the Brule. Over many millennia, ground water in the Brule that had originated in the Ogallala and that contained a strong calcium signature could have, through ion exchange, had most of the calcium replaced by sodium.

Nitrate concentrations were largest in water samples collected from monitoring wells located in Lodgepole Creek Valley and tableland draw areas (up to $10 \mathrm{mg} / \mathrm{L}$ ), equaling the U.S. Environmental Protection Agency's (USEPA) Maximum Contaminant Level (MCL) (U.S. Environmental Protection Agency, 2002) and smallest in the tableland areas (up to $4.4 \mathrm{mg} / \mathrm{L}$ ). The median nitrate concentration from samples in the tableland draw areas was more than twice that of samples from Lodgepole Creek Valley-4.4 mg/L and $2.1 \mathrm{mg} / \mathrm{L}$, respectively (table 5 in Appendix). Median nitrate concentrations by aquifer were $2.6 \mathrm{mg} / \mathrm{L}$ (Ogallala), $2.1 \mathrm{mg} / \mathrm{L}$ (Brule), and $1.3 \mathrm{mg} / \mathrm{L}$ (Brule sand) (table 2).

Areally, no significant difference between median nitrate concentrations in water samples collected in Lodgepole Creek Valley as compared to water samples collected in the tableland areas or the tableland draw areas was seen ( $\mathrm{p}$-values $=0.9580$ and 0.1083 , respectively; table 3 ). There was a significant difference, however, in median nitrate concentrations between water samples collected in the tableland areas and the tableland draw areas $(\mathrm{p}$-value $=0.0162)($ table 3$)$. 


\section{(A) lonic composition by aquifer}

\section{EXPLANATION}

- Ogallala Group (Ogallala aquifer)

- Brule Formation (Brule aquifer)

- Brule Formation sand (Brule sand aquifer)

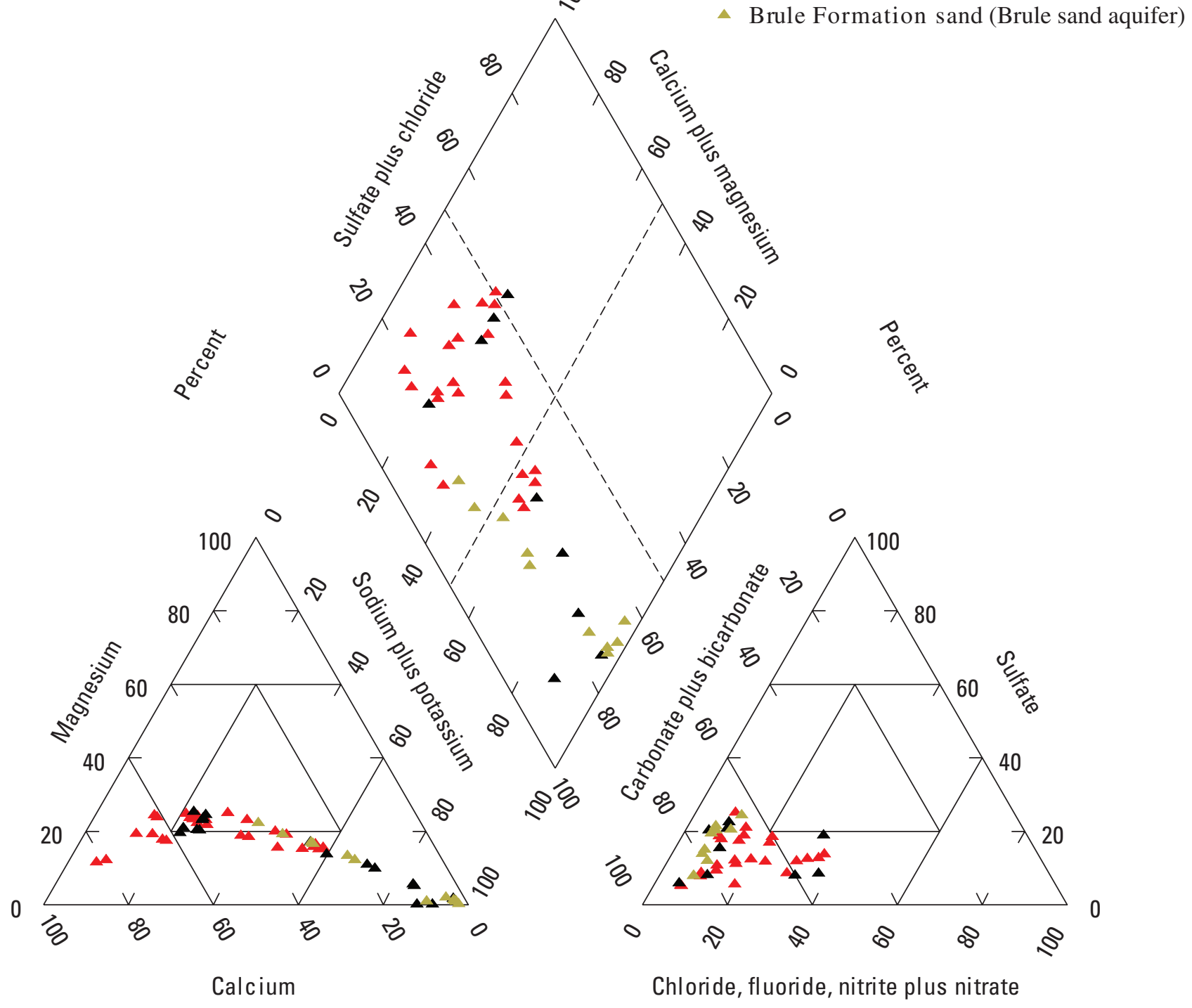

PERCENTAGE OF MILLIEQUIVALENTS PER LITER

Figure 10. Ionic composition of ground water (A) by aquifer and (B) by location in the study area, 2004-05.

Results from a monitoring well in or adjacent to agricultural fields did not always indicate that nitrate concentrations in ground-water samples were large, especially in the tableland areas. However, some of the tableland draw monitoring wells at the eastern end of the study area had water samples with large nitrate concentrations. The source of large nitrate concentrations in these samples likely is nonpoint-source contamination following application of nitrogen fertilizers to agricultural fields. Recharging ground water carrying excess nitrogen fertilizers to the Ogallala-Brule interface may flow along this interface and migrate to areas where the tableland draw monitoring wells are located. In Lodgepole Creek Valley, large nitrate concentrations have been observed for years, and evidence exists that nonpoint-source contamination is occurring in Lodgepole Creek Valley (Gottula, 1997). This area is intensively agricultural, and excess nitrogen from the fertilizer applications could migrate through the thin alluvium in Lodgepole Creek Valley.

Large aluminum, arsenic, boron, and strontium concentrations were found in some ground-water samples, but small iron and manganese concentrations were found (typically less than laboratory reporting levels) (table 7 in the Appendix).

The likely source for the large aluminum concentrations could not be identified, but the source for the large arsenic and boron concentrations likely is natural. As mentioned previously, aluminum concentrations (USEPA Secondary Drinking-Water 


\section{(B) Ionic composition by location}

\section{EXPLANATION}

- Lodgepole Creek Valley

- Tableland areas

- Tableland draws

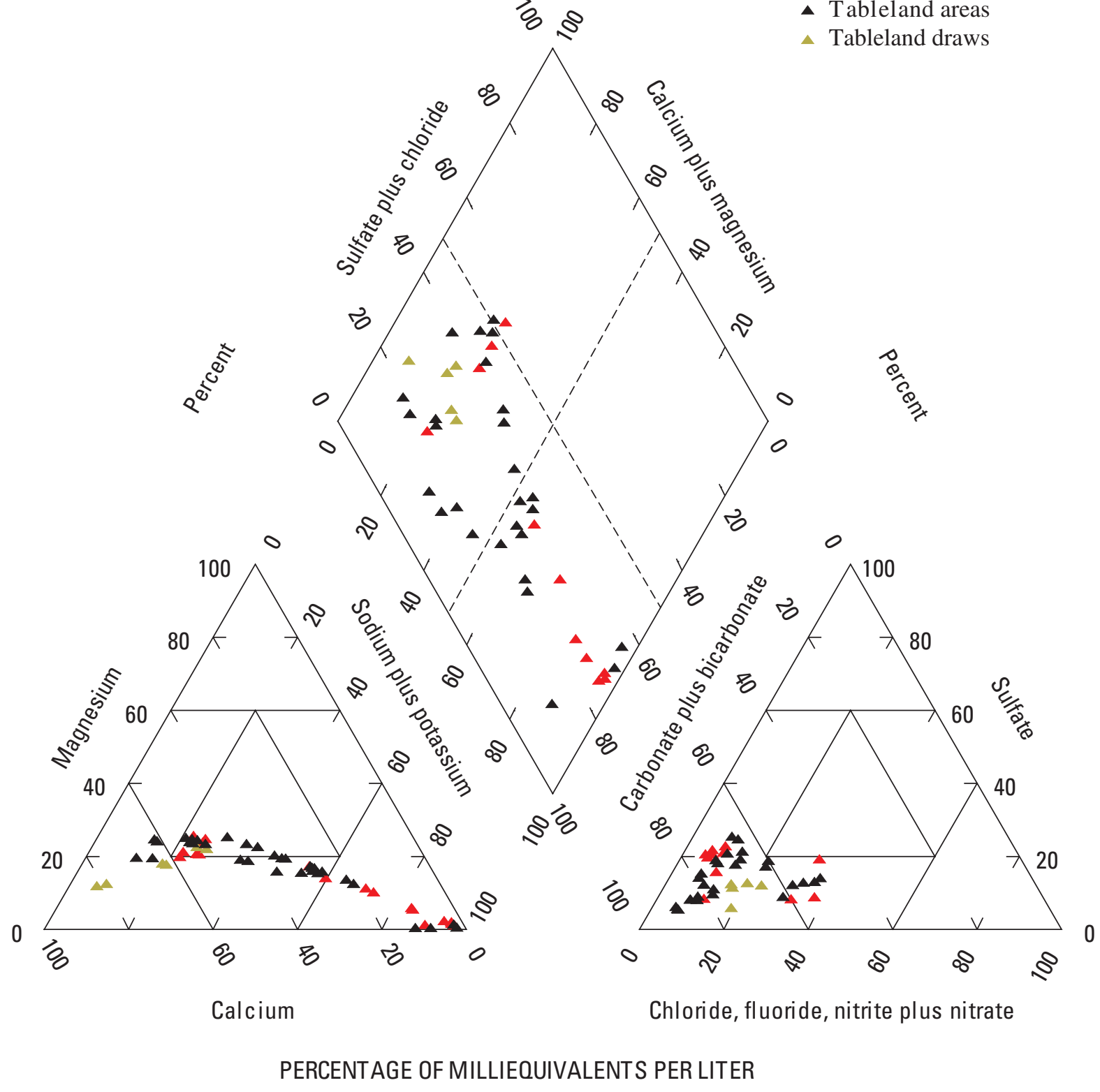

Figure 10. Ionic composition of ground water $(A)$ by aquifer and $(B)$ by location in the study area, 2004-05.-Continued

Regulation of 0.05 to $0.2 \mathrm{mg} / \mathrm{L}$; U.S. Environmental Protection Agency, 2002) were very large $(2,000 \mu \mathrm{g} / \mathrm{L})$ in monitoring well CT03-D (table 7) and are thought to be the result of not being able to purge the well adequately. Inadequate purging of wells also may account for detections of large concentrations of aluminum in water samples from monitoring wells CT01-D and CL16-D, both of which had aluminum concentrations of $60 \mu \mathrm{g} / \mathrm{L}$. However, in water samples from monitoring well CL16-D, the concentration of aluminum decreased substantially (60 to $9 \mu \mathrm{g} / \mathrm{L}$ ) from April 2004 to April 2005. This provides further evidence that the initial development of the very small yield monitoring wells may have been insufficient.
Arsenic concentrations in ground water ranged from $2 \mu \mathrm{g} / \mathrm{L}$ (Ogallala) to $47 \mu \mathrm{g} / \mathrm{L}$ (Brule sand) (table 7) with a mean of $8.4 \mu \mathrm{g} / \mathrm{L}$. Forty-seven percent of the ground-water samples ( 27 of 58 samples from 15 different monitoring wells) analyzed for arsenic equaled or exceeded the USEPA MCL of $0.010 \mathrm{mg} / \mathrm{L}(10 \mu \mathrm{g} / \mathrm{L})$ for drinking water, and most samples were associated with the Brule or Brule sand aquifers. Median concentrations of arsenic by aquifer were $5.6 \mu \mathrm{g} / \mathrm{L}$ (Ogallala), $8.0 \mu \mathrm{g} / \mathrm{L}$ (Brule), and $12 \mu \mathrm{g} / \mathrm{L}$ (Brule sand). These median concentrations indicate that water in the Brule sand contained larger arsenic concentrations than water in the Brule or Ogallala. 
Table 3. Statistical comparison of median constituent concentrations in ground-water samples by aquifer and location near Sidney, western Nebraska, 2004-05.

[vs., versus; shaded cells indicate no statistically significant difference; $\alpha$ equals 0.05 ]

\begin{tabular}{|c|c|c|c|c|c|c|}
\hline \multirow[b]{3}{*}{ Constituent } & \multicolumn{6}{|c|}{ p-value (rank-sum test) } \\
\hline & \multicolumn{3}{|c|}{ Aquifer } & \multicolumn{3}{|c|}{ Location } \\
\hline & $\begin{array}{c}\text { Ogallala vs. } \\
\text { Brule }\end{array}$ & $\begin{array}{l}\text { Ogallala vs. } \\
\text { Brule sand }\end{array}$ & $\begin{array}{l}\text { Brule vs. Brule } \\
\text { sand }\end{array}$ & $\begin{array}{l}\text { Lodgepole Creek } \\
\text { Valley vs. table- } \\
\text { land areas }\end{array}$ & $\begin{array}{l}\text { Lodgepole Creek } \\
\text { Valley vs. table- } \\
\text { land draws }\end{array}$ & $\begin{array}{c}\text { Tableland draws } \\
\text { vs. tableland } \\
\text { areas }\end{array}$ \\
\hline Calcium & 0.0698 & 0.0054 & 0.4220 & 0.6542 & 0.1508 & 0.0219 \\
\hline
\end{tabular}

Large boron and strontium concentrations in groundwater samples were not measured as frequently as large arsenic concentrations. Concentrations of boron ranged from 17 to $485 \mu \mathrm{g} / \mathrm{L}$ with a median of $80 \mu \mathrm{g} / \mathrm{L}$. Where boron concentrations exceeded $200 \mu \mathrm{g} / \mathrm{L}$ in ground-water samples (10 of 58 samples), they were concomitant with arsenic samples that, except for two samples from monitoring well CL12 (each sample had $13 \mu \mathrm{g} / \mathrm{L}$ ), equaled or exceeded $24 \mu \mathrm{g} / \mathrm{L}$. Strontium concentrations ranged from 53 to $1,100 \mu \mathrm{g} / \mathrm{L}$ with a median of $399 \mu \mathrm{g} / \mathrm{L}$.

Ground-water chemistry of the study area indicates that ground water flows from recharge areas in both the tableland areas and Lodgepole Creek Valley to discharge areas beyond the study area or, less likely, within the study area. Ground water that percolates downward into the Ogallala in the tableland areas either remains in the limited saturated zone of the Ogallala and becomes a part of the Ogallala aquifer or moves downward to the Brule where it either flows along the Ogallala-Brule contact or it enters Brule fractures or sand where it flows to beyond the study area. If ground water in the Brule north of the valley flows to the south, it eventually flows to Lodgepole Creek Valley where it may be captured by irrigation or production wells prominent in the valley. Ground-water flow along the Ogallala-Brule contact or in the Brule or Brule sand appears to be the predominant means by which water moves from the tableland areas to Lodgepole Creek Valley, although the volume of water that actually flows from the tableland areas into Lodgepole Creek Valley likely is small.

\section{Age of Ground Water}

The reader should remember that in this report all discussion of the "age" of ground water refers only to an apparent age. Moreover, unless otherwise discussed, this apparent age assumes piston flow. Also, the age of the ground water refers to the date the sampled gas $\left(\mathrm{CFC}, \mathrm{SF}_{6}\right.$, or $\left.{ }^{3} \mathrm{H} /{ }^{3} \mathrm{He}\right)$ was introduced into the aquifer and isolated from the atmosphere. It is not the actual age of the water. For brevity, in this report "apparent recharge age" is the same as "age" of the water. The accuracy of the CFC-based age depends, in part, on how effectively the CFC was transported with ground-water flow (Plummer and Busenberg, 2000).

Water samples collected from 7 of the 29 ground-water monitoring wells (table 8 in the Appendix) were analyzed for concentrations of CFCs (CFC-11, CFC-12, and CFC-113). $\mathrm{CFC}$ concentrations were less than those found in modern air; therefore, apparent ages could be assigned. In addition, all water samples were examined further using three flow or mixing scenarios-piston flow, binary mixing (old water mixed with young water), and exponential mixing (infinite number of inputs, such as a well with a long screened interval).

Sensitivity testing (how closely the CFC age is affected by changes in temperature or elevation and different CFC mixing scenarios associated with piston, binary, or exponential flow characteristics) of CFC data indicate that the previously described assumptions were valid and the age of water associated with the samples was practical. Sensitivity testing of the CFC data to differing scenarios-piston, binary, or exponential flow characteristics - did not refute the original hypothesis that piston flow dominated the ground-water flow in the study area. However, it was clear that some binary mixing (mixing of young and old water) had occurred.

No reducing conditions were found in any water samples analyzed for CFCs. Therefore, degradation of CFCs likely was negligible, and if degradation occurred, it was limited to CFC -11 and CFC-113, which typically are not as stable as CFC-12 (Plummer and Busenberg, 2000). As a result, the age of the water was reported for most of the CFC data.

Ground-water ages from $\mathrm{CFC}$ and $\mathrm{SF}_{6}$ data generally were in agreement. However, $\mathrm{CFC}$ and $\mathrm{SF}_{6}$ ages from one water sample (monitoring well CL09) indicated a substantial age difference. At this site, CFC age for the ground water was in the mid-1970s; however, the $\mathrm{SF}_{6}$ age was about 1991. Binary mixing of CFC-113 as a function of CFC-11 and $\mathrm{CFC}-12$ indicated the possibility of a CFC age around 1990 and 1985, respectively. Although these binary mixing scenarios are inconclusive, they are likely because they are close to the ages observed from $\mathrm{SF}_{6}$ and ${ }^{3} \mathrm{H} /{ }^{3} \mathrm{He}$ data. Similar to monitoring well CL05 (which contained the oldest CFCderived ages in Lodgepole Creek Valley), monitoring well CL09 is located in close proximity to the escarpment that forms the tableland areas to the north of Lodgepole Creek Val- 
ley (fig. 5). Consequently, it is probable that old water seeping from the tableland areas intermixes with younger water in the alluvium. Therefore, the apparent age for ground-water samples at monitoring well CL09 reflects a combination of older (1970s) and younger mid-1980s to 1990 water. Ages of ground water for other monitoring wells located in Lodgepole Creek Valley ranged from the mid- to late 1960s (monitoring well CL05) to the early 1990s (monitoring wells SD3 and M16). Ages of ground water in monitoring wells located in tableland draw areas ranged from the mid-1980s to the early 1990s. Water from a single monitoring well (CD10-S) sampled for $\mathrm{CFC}$ and $\mathrm{SF}_{6}$ concentrations in the tableland areas contained an apparent age date of the mid-1980s (table 8).

Results of ${ }^{3} \mathrm{H} /{ }^{3} \mathrm{He}$ sampling indicate that much of the ground water in the study area was younger than 30 years old and generally supported the results of the CFC data. Although some differences between $\mathrm{CFC}$ and ${ }^{3} \mathrm{H} /{ }^{3} \mathrm{He}$ dates were greater than 10 years, the median difference was about 3 years. Three years also was the median difference in ground-water ages analyzed using ${ }^{3} \mathrm{H} /{ }^{3} \mathrm{He}$ and $\mathrm{SF}_{6}$. One ${ }^{3} \mathrm{H} /{ }^{3} \mathrm{He}$ age was determined to be about 1937 (monitoring well CL19-S). However, the age obtained from this water sample borders on the precision of the ${ }^{3} \mathrm{H} /{ }^{3} \mathrm{He}$ technique, and it could suggest a problem with ${ }^{3} \mathrm{He}$ loss through predominantly diffusive transport in low recharge areas. Solomon and Cook (2000) reported downward advective transport retains ${ }^{3} \mathrm{He}$ concentrations in ground water. Therefore, if diffusive instead of advective transport is dominant and assuming a porosity of 30 percent, ${ }^{3} \mathrm{He}$ can be transported from ground water to interstitial air just above it. Furthermore, ${ }^{3} \mathrm{He}$ losses can be less than 20 percent in areas receiving less than $1.2 \mathrm{in} / \mathrm{yr}$ recharge if advective transport dominates. However, if diffusion dominates, ${ }^{3} \mathrm{He}$ losses can be greater than 80 percent in areas receiving less than $0.12 \mathrm{in} / \mathrm{yr}$ recharge (Solomon and Cook, 2000). Also, if diffusion dominates and ${ }^{3} \mathrm{He}$ is transported to the water table, little information on ground-water age is retained from ${ }^{3} \mathrm{He}$ concentrations. Because the study area is classified as semiarid, recharge rates would tend to be low, and thus, much of the ${ }^{3} \mathrm{He}$ could be lost from diffusion. This would explain this large discrepancy between age dates derived from $\mathrm{CFC}$ and ${ }^{3} \mathrm{H} /{ }^{3} \mathrm{He}$ data.

The only other water sample with age differences larger than 10 years (about 22 years between $\mathrm{CFC}$ and ${ }^{3} \mathrm{H} /{ }^{3} \mathrm{He}$ data) was from monitoring well CL09. However, the difference between $\mathrm{SF}_{6}$ and ${ }^{3} \mathrm{H} /{ }^{3} \mathrm{He}$ derived ground-water age in this sample was only about 6 years, whereas the CFC data indicated a mid-1970s age. Binary mixing analysis of the water in this well shows possible mixing of water such that ages are around 1985 (CFC-113 as a function of CFC-12) to 1990 (CFC-113 as a function of $\mathrm{CFC}-11$ ). Therefore, using binary mixing, the difference is reduced to about 4 years between $\mathrm{CFC}$ and $\mathrm{SF}_{6}$, and 10 years between the $\mathrm{CFC}$ and ${ }^{3} \mathrm{H} /{ }^{3} \mathrm{He}$ age dates.

The values of ${ }^{14} \mathrm{C}$ in water samples from two monitoring wells completed in the Brule and two monitoring wells completed in Brule sand ranged from 1.8 to $59 \mathrm{pmC}$. In addition, these samples were isotopically light in ${ }^{13} \mathrm{C} /{ }^{12} \mathrm{C}$ relative to the standard. The $\delta^{13} \mathrm{C}$ ratios ranged from -10.69 to -7.56 per mil, which falls within the mean composition of $\delta^{13} \mathrm{C}$ ratios typical of $\mathrm{C}_{4}$ plants (Feggestad and others, 2004). Feggestad and others (2004) reported that $\mathrm{C}_{4}$ plants include warm-season grasses, which characteristically grow during the warmest and driest months of the year. Correcting for $\delta^{13} \mathrm{C}$ gave apparent radiocarbon ages ranging from about $30,000 \mathrm{ybp}$ to present. The oldest water was observed in samples from monitoring well CT01-D, which indicated a ${ }^{14} \mathrm{C}$ age date of about 28,000 ybp; samples from monitoring well CL19-D indicated a ${ }^{14} \mathrm{C}$ age of about $14,000 \mathrm{ybp}$ (table 8 ). Age dating of water samples from the other two wells indicated much younger water-1,400 ybp (monitoring well CT02-D) and modern (monitoring well CT18). The water from these two monitoring wells is not necessarily younger than water from monitoring wells CT01-D or CL19; rather much younger water likely is mixing with very old water, and this mixing is indicating modern ages. As indicated from the ${ }^{14} \mathrm{C}$ age, water in the Brule (areas without known secondary permeability structures) or deeper Brule sand is substantially older than water in the Ogallala and probably recharged between 10,000 to $30,000 \mathrm{ybp}$.

\section{Isotopic Data}

Clark and Fritz (1997) reported that $\delta^{18} \mathrm{O}$ and $\delta^{2} \mathrm{H}$ signatures of water are shifted below the local meteoric waterline (LMWL) by most meteoric and subsurface processes. In the study area this shift was not evident from stable isotope $\left({ }^{18} \mathrm{O}\right.$ and $\left.{ }^{2} \mathrm{H}\right)$ water samples. Results indicate that most water samples likely originated from meteoric water with minor secondary refractive processes_-such as evaporation. This was evident from the displacement of the $\delta^{18} \mathrm{O}$ and $\delta^{2} \mathrm{H}$ data below the LMWL (fig. 11). Steele and others (2005) reported that most of the ground-water samples collected from monitoring wells in alluvial and fractured Brule aquifers in Pumpkin Creek Valley (about $30 \mathrm{mi}$ northwest of the study area, fig. 1) were somewhat isotopically heavier than water samples collected from monitoring wells in the Brule aquifer. Furthermore, there appeared to be a clear isotopic distinction between ground water obtained from shallow alluvial and fractured Brule aquifers and ground water obtained from the Brule. Although Pumpkin Creek and Lodgepole Creek Valleys are close geographically and similar in several aspects, a clear isotopic distinction between water samples from those sources is not evident in this study area. Unlike Pumpkin Creek Valley, where secondary evaporative processes appear to play an important role, here water samples indicate little to no secondary refractive processes. Therefore, stable isotopic data indicate that ground water in the study area probably originated from precipitation rather than infiltration from surficial sources.

Clark and Fritz (1997) also reported that there is a strong correlation between temperature and $\delta^{18} \mathrm{O}$ and $\delta^{2} \mathrm{H}$, which in turn reflect the isotopes' position on a graph. The lower end of a graph showing $\delta^{2} \mathrm{H}$ as a function of $\delta^{18} \mathrm{O}$ typically is dominated by ground water recharged from precipitation that fell 

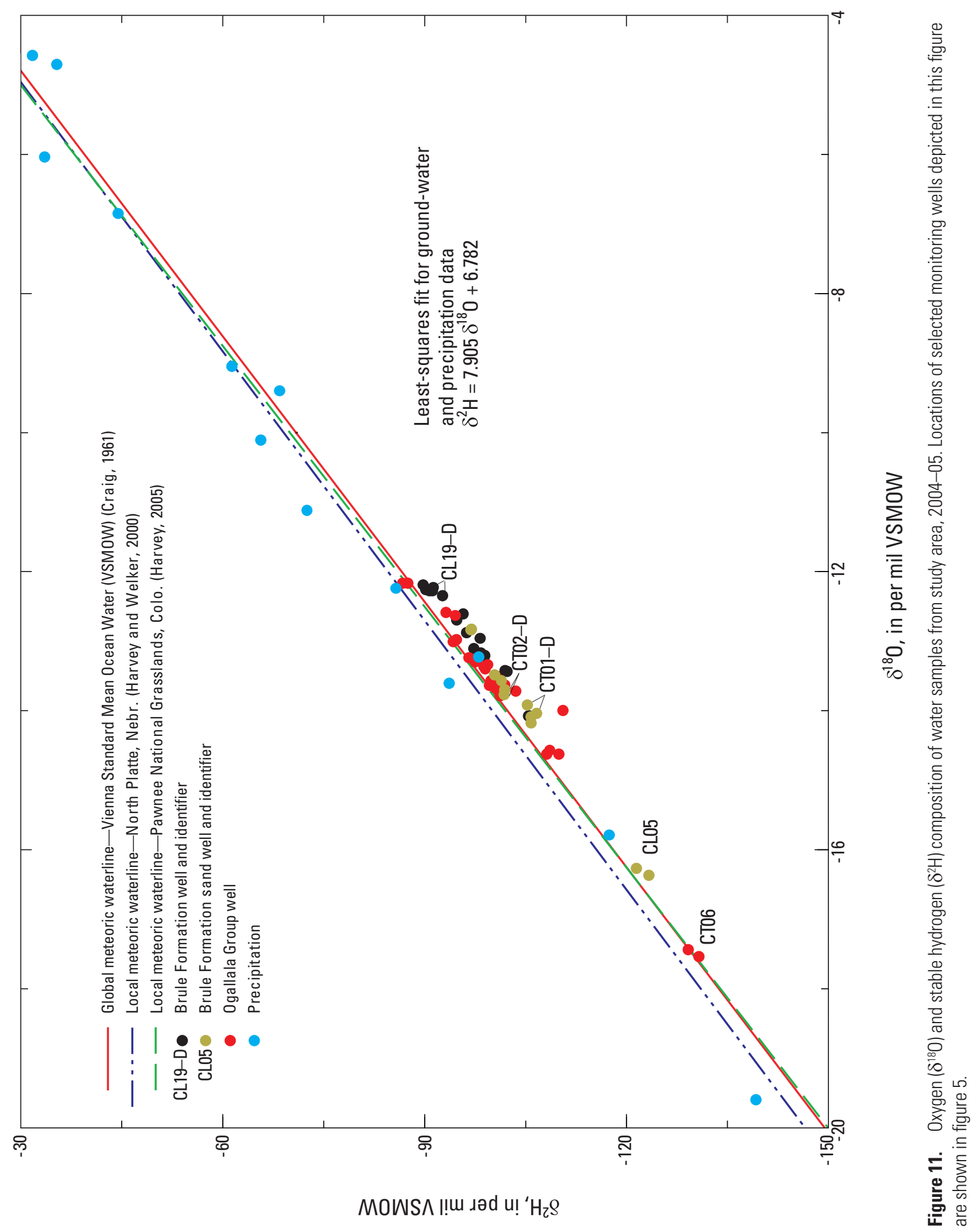
during a process called "rainout" where heavier isotopes get distilled from the vapor mass (Clark and Fritz, 1997). Data on the lighter (lower) end of the graph also are indicative of cooling air masses distant from oceanic sources.

Four water samples analyzed for ${ }^{14} \mathrm{C}$ indicated that the mean composition of $\delta^{13} \mathrm{C}$ ratios was typical of $\mathrm{C}_{4}$ plants (Feggestad and others, 2004). Water samples indicate that $\delta^{18} \mathrm{O}$ and $\delta^{2} \mathrm{H}$ values all were not in the isotopically lighter end of the graph (fig. 11), which would be suggestive of $\mathrm{C}_{3}$ plants (Feggestad and others, 2004). Although isotopic values and ${ }^{14} \mathrm{C}$ age dates of water samples from Brule monitoring wells in Pumpkin Creek Valley (5,000 to 10,000 ybp) indicated likely recharge during a different climatic era (Steele and others, 2005), water samples from Brule monitoring wells in the study area indicated older water samples (30,000 ybp). In addition, ${ }^{14} \mathrm{C}$ age dates and isotopic signatures of water samples from four monitoring wells in the study area were all concordant and indicated that the atmospheric temperature during recharge likely was warmer as indicated by the $\delta^{13} \mathrm{C}$ ratios and isotopic signatures.

\section{Source of Ground-Water Recharge}

As shown by isotopic data, precipitation is the primary source of ground-water recharge in the Sidney area. In the tableland areas north of Sidney, a ground-water divide exists that (1) causes most ground water north of the divide to generally move northeast and (2) curtails much of the southern flow of water towards Lodgepole Creek. It is evident that some ground water flows from the ground-water divide toward Lodgepole Creek. However, on the basis of small saturated thickness and the makeup of geological deposits from the tableland areas near the ground-water divide and the northern side of Lodgepole Creek Valley, it is likely that most ground water in the tableland areas flows northeasterly where it intersects larger aquifer systems and eventually discharges into the North Platte River Basin (not shown on any maps) or much farther down Lodgepole Creek Valley.

Similar to the tableland areas, much of the ground-water recharge to Lodgepole Creek Valley is from precipitation. However, in Lodgepole Creek Valley ground water largely enters from upgradient areas within the valley itself and is augmented by what water is available from the tableland areas. Although ground water in Lodgepole Creek Valley and the tableland areas is similar in chemistry, there appears to be limited interaction between ground water within the Ogallala aquifer north of Sidney and Lodgepole Creek Valley. Most water flow from tableland areas into Lodgepole Creek Valley would be through myriad unmapped fractures or piping within the Brule and along the Ogallala-Brule contact. Available data indicate that although some of the ground water in the Ogallala likely flows across the Ogallala-Brule contact, most of it does not move toward Lodgepole Creek.

\section{Summary}

Ground water in the Lodgepole Creek area of western Nebraska currently is developed to the extent that during times of drought sufficient yields may not be available for private and municipal supplies. In the Sidney area, alternate sources of water exist in the Cheyenne Tablelands north of the city. Therefore, an evaluation of ground-water flow in the general area north of Sidney and how the ground water in the tableland areas interacts with ground water in Lodgepole Creek Valley would enhance understanding of the ground-water system.

The 122-mi ${ }^{2}$ study area lies in the south-central part of Cheyenne County and is characterized by two distinct regions-incised valleys and upland plains. The valleys of Lodgepole Creek, the predominant watercourse of the study area, and Sidney Draw occupy the southern and western parts of the study area. The Cheyenne Tablelands constitute most of the northern part of the study area.

Lodgepole Creek Valley is very intensely irrigated in the study area with several wells open to aquifers in the Brule or both the Brule and the overlying alluvial aquifer. The saturated thickness of the alluvial aquifer is too thin to yield sufficient quantities to irrigation wells; therefore, these wells also must be augmented with supplies from fractures within the Brule. In contrast, the Cheyenne Tablelands are predominantly nonirrigated cropland and rangeland with sparsely distributed irrigation wells developed in the Ogallala or discrete paleochannels in the Brule.

The surficial ground-water resources in the study area are limited to three geologic units- the undifferentiated alluvial deposits found along Lodgepole Creek and the Ogallala Group (Ogallala) and Brule Formation of the White River Group (Brule). The siltstone of the Brule can exceed $600 \mathrm{ft}$ in thickness and underlies undifferentiated alluvial deposits in Lodgepole Creek Valley and the Ogallala in the tableland areas. In Lodgepole Creek Valley, the fractured Brule is considered a major aquifer because of its ability to yield large quantities of water with little drawdown. In areas where the Brule is an unfractured siltstone, it is considered to be the base of either (1) the shallow alluvial aquifer system in the Lodgepole Creek Valley or (2) the regional aquifer system under the Cheyenne Tablelands. Where the Brule is fractured, hydraulic conductivity and well yield values in the study area likely range from 3,000 to $20,000 \mathrm{ft} / \mathrm{d}$. Where the White River Group is unfractured, hydraulic conductivity values of less then $2.7 \times 10^{-2} \mathrm{ft} / \mathrm{d}$ are reported.

The Ogallala Group, containing individual beds of unconsolidated sand and gravel deposits with little or no silt and with thicknesses of $70 \mathrm{ft}$ or more, is an important aquifer north of Lodgepole Creek because it discharges some water to Lodgepole Creek Valley. South of Lodgepole Creek, the Ogallala is mostly unsaturated. But north of Lodgepole Creek the Ogallala is a good source of water where saturated, and irrigation wells in Cheyenne County (north of Lodgepole Creek) yield an average of about $820 \mathrm{gal} / \mathrm{min}$ with a reported 
range of 100 to $2,200 \mathrm{gal} / \mathrm{min}$. Transmissivity values of the channel sand in the tableland areas north of Sidney was about $27,000 \mathrm{ft}^{2} / \mathrm{d}$, the hydraulic conductivity was about $600 \mathrm{ft} / \mathrm{d}$, and the specific yield ranged between 0.20 and 0.25 .

Ground water appears to be limited in extent in the tableland areas with depths to ground water ranging from 95 to $188 \mathrm{ft}$ in spring 2005. In Lodgepole Creek Valley depths to water ranged from near the land surface to $91 \mathrm{ft}$. The approximate direction of ground-water flow for much of the study area is from recharge areas in the north and west toward Lodgepole Creek. Ground water in the tableland areas north of the divide flows northeasterly toward the North Platte Valley and its tributaries; whereas south of the divide flow moves in a southeasterly direction toward Lodgepole Creek. Ground water in Lodgepole Creek Valley moves toward Lodgepole Creek where it generally flows toward or parallel to the creek, or occasionally discharges into Lodgepole Creek.

Measurements of the physical characteristics of ground water varied in the study. Specific conductance values in ground-water samples ranged from 290 to $2,710 \mu \mathrm{S} / \mathrm{cm}$, and water samples from the Brule aquifer contained slightly larger median specific conductance values $(511 \mu \mathrm{S} / \mathrm{cm})$ than water samples from the Brule sand $(446 \mu \mathrm{S} / \mathrm{cm})$ or the Ogallala $(405 \mu \mathrm{S} / \mathrm{cm})$. Measurements of $\mathrm{pH}$ and water temperature in ground-water samples from the study area ranged from 7.2 to 11.9 standard units and 8.5 to $18.0^{\circ} \mathrm{C}$, respectively. Measurements of dissolved oxygen in ground-water samples from the study area ranged from 0.1 to $8.5 \mathrm{mg} / \mathrm{L}$, and alkalinity ranged from 98 to $582 \mathrm{mg} / \mathrm{L}$ as $\mathrm{CaCO}_{3}$.

Water samples from Ogallala monitoring wells were predominantly a calcium bicarbonate type, whereas those from Brule monitoring wells were a sodium bicarbonate type. Water samples from monitoring wells open to shallow Brule sand contained a calcium bicarbonate signature, and those from monitoring wells open to deeper Brule sand contained a sodium bicarbonate signature. This indicated that the shallower Brule sand has a hydraulic connection with the overlying Ogallala Group, whereas the deeper sand is more isolated. Water samples collected from monitoring wells located in the tableland draws mostly had a strong calcium signature indicating that the Ogallala was the source of water for these wells. The signature of the ground water in Lodgepole Creek Valley was strongly sodium, likely resultant of most wells being open to the Brule. Over many millennia, ground water in the Brule that originated in the Ogallala and contained a strong calcium signature could have, through ion exchange, had most of the calcium replaced by sodium.

Comparison of concentrations of sodium $(\mathrm{p}$-value $=$ $0.0062)$ and nitrate $(\mathrm{p}$-value $=0.0249)$ from the Ogallala aquifer and the Brule aquifer indicated significant differences existed between water samples from the two aquifers. Calcium ( $\mathrm{p}$-value $=0.0054)$, sodium $(\mathrm{p}$-value $=0.0165)$, and nitrate ( $\mathrm{p}$-value $=0.0168)$ concentrations from the Ogallala aquifer compared to the Brule sand aquifer also indicated significant differences. However no statistical inference could be made for calcium concentrations in water samples collected from the
Ogallala aquifer as compared to water samples collected from the Brule aquifer $(p$-value $=0.0698)$ or in calcium or nitrate concentrations in water samples collected from the Brule aquifer and the Brule sand aquifer ( $\mathrm{p}$-values $=0.4220$ and 0.3746, respectively). Significant differences in sodium concentrations from water samples collected from the Brule and Brule sand $(p$-value $=0.8991)$ could not be inferred statistically.

The median nitrate concentration from samples in the tableland draw areas was more than twice that of samples from Lodgepole Creek Valley-4.4 and $2.1 \mathrm{mg} / \mathrm{L}$, respectively. Median nitrate concentrations by aquifer were $2.6 \mathrm{mg} / \mathrm{L}$ (Ogallala), $2.1 \mathrm{mg} / \mathrm{L}$ (Brule), and $1.3 \mathrm{mg} / \mathrm{L}$ (Brule sand). Concentrations of arsenic in ground-water samples ranged from 2 to $47 \mu \mathrm{g} / \mathrm{L}$ with a median of $8.4 \mu \mathrm{g} / \mathrm{L}$, and concentrations of boron ranged from 17 to $485 \mu \mathrm{g} / \mathrm{L}$ with a median of $80 \mu \mathrm{g} / \mathrm{L}$. Where boron concentrations exceeded $200 \mu \mathrm{g} / \mathrm{L}$ in ground-water samples (10 of 58 samples), they usually were accompanied by arsenic concentrations that exceeded $24 \mu \mathrm{g} / \mathrm{L}$. Strontium concentrations ranged from 53 to $1,100 \mu \mathrm{g} / \mathrm{L}$ with a median of $399 \mu \mathrm{g} / \mathrm{L}$.

The chemistry of the ground water in the study area indicates that ground water flows from recharge areas in both the tableland areas and Lodgepole Creek Valley to discharge areas beyond the study area. Some discharge may occur within the study area, but this is less likely. Ground water that percolates into the Ogallala in the tableland areas (1) either becomes a part of the Ogallala aquifer or (2) moves downward to the Brule where it either flows along the Ogallala-Brule contact or it enters Brule fractures or sand. Ground water that flows along the Ogallala-Brule contact or in the Brule or Brule sand appears to be the predominant means by which water moves from the tableland areas to Lodgepole Creek Valley, although the volume of water that actually flows from the tableland areas into Lodgepole Creek Valley likely is small.

Apparent ground-water ages from $\mathrm{CFC}$ and $\mathrm{SF}_{6}$ data generally were concordant. Age of ground water for most monitoring wells located in Lodgepole Creek Valley ranged from the mid- to late 1960s to the early 1990s. Ages of ground water in samples from monitoring wells located in tableland draw areas ranged from mid-1980s to early 1990s. The water from a single monitoring well sampled in the tableland areas contained an apparent age date of the mid-1980s. Results of ${ }^{3} \mathrm{H} /{ }^{\beta} \mathrm{He}$ sampling indicate that much of the ground water in the study area was younger than 30 years old and generally supported the results of the CFC data. Three years was the median difference in ground-water ages analyzed using ${ }^{3} \mathrm{H} /{ }^{\beta} \mathrm{He}$ and $\mathrm{SF}_{6}$.

The values of ${ }^{14} \mathrm{C}$ in water samples from two monitoring wells completed in the Brule aquifer and two monitoring wells completed in the Brule sand aquifer ranged from 1.8 to $59 \mathrm{pmC}$. Correcting for $\delta^{13} \mathrm{C}$ gave apparent radiocarbon age dates that ranged from present to about 30,000 ybp. Water in the Brule (areas without known secondary permeability structures) or deeper Brule sand aquifer is substantially older than water in the Ogallala aquifer and was probably recharged between 10,000 to 30,000 ybp. Radiocarbon dating and the 
isotopic signatures of the water samples from these four monitoring wells were concordant and indicate that the temperature during this time likely was warmer as indicated by the $\delta^{13} \mathrm{C}$ ratios and the isotopic signatures.

There appears to be no clear oxygen and hydrogen isotopic distinctions between ground-water samples from the Brule aquifer and those in the overlying Ogallala aquifer. The stable isotopic data indicate that the ground water in the study area probably originated from precipitation rather than infiltration from surficial sources.

Ground water in Lodgepole Creek and the tableland areas is similar in chemistry. However, there appears to be limited interaction between ground water within the Ogallala to the north of Sidney and Lodgepole Creek Valley. Available data indicated that, although some of the ground water in the Ogallala likely flows across the Ogallala-Brule contact, most of it does not move toward Lodgepole Creek.

\section{References Cited}

Barrash, Warren, 1986, Hydrostratigraphy and hydraulic behavior of fractured formation in Sidney Draw, Cheyenne County, Nebraska: Moscow, University of Idaho, doctoral dissertation, 205 p., 4 plates.

Barrash, Warren, and Ralston, D.R., 1991, Analytical modeling of a fracture zone in the Brule Formation as an aquifer receiving leakage from a water-table and elastic aquitards: Journal of Hydrology, v. 125, no. 1-2, p. 1-24.

Bjorklund, L.J., 1957, Geology and ground-water resources of the lower Lodgepole Creek drainage basin, Nebraska, with a section on The chemical quality of the water, by E.R. Jochens: U.S. Geological Survey Water-Supply Paper 1410, 76 p., 4 plates.

Bryda, A.P., 1988, Nitrate-nitrogen profiles documenting land use practice effects on ground water in and around Sidney, Nebraska: Lincoln, University of Nebraska-Lincoln, unpublished master's thesis, $119 \mathrm{p}$.

Bullen, T.D., and Kendall, Carol, 1998, Tracing of weathering reactions and water flowpaths-a multi-isotope approach, chap. 18 of Kendall, Carol, and McDonnell, J.J., eds., Isotope tracers in catchment hydrology: Amsterdam, Elsevier Publications, p. 611-646.

Busenberg, Eurybiades, and Plummer, L.N., 1992, Use of chlorofluorocarbons $\left(\mathrm{CCL}_{3} \mathrm{~F}\right.$ and $\left.\mathrm{CCl}_{2} \mathrm{~F}_{2}\right)$ as hydrologic tracers and age-dating tools - the alluvium and terrace system of central Oklahoma: Water Resources Research, v. 28, no. 9, p. 2257-2283.
Busenberg, Eurybiades, and Plummer, L.N., 1997, Use of sulfur hexafluoride as a dating tool and as a tracer of igneous and volcanic fluids in ground water: Geological Society of America, 1997 Annual Meeting, Abstracts with Programs, v. 29 , no. 6 , p. A-78.

Busenberg, Eurybiades, and Plummer, L.N., 2000, Dating young groundwater with sulfur hexafluoride-natural and anthropogenic sources of sulfur hexafluoride: Water Resources Research, v. 36, no. 10, p. 3011-3030.

Busenberg, Eurybiades, Plummer, L.N., Bartholomay, R.C., and Wayland, J.E., 1998, Chlorofluorocarbons, sulfur hexafluoride, and dissolved permanent gases in ground water from selected sites in and near the Idaho National Engineering and Environmental Laboratory, Idaho, 1994-97: U.S. Geological Survey Open-File Report 98-274, 72 p.

Center for Advanced Land Management Information Technologies, 2005, 2005 land use mapping in the Central Platte River Basin: University of Nebraska-Lincoln, information available on Web, accessed August 15, 2006, at http://calmit.unl.edu/2005landuse/central_platte.shtm

Clark, I.D., and Fritz, Peter, 1997, Environmental isotopes in hydrogeology: Boca Raton, Lewis Publishers, 328 p.

Cook, P.G., and Solomon, D.K., 1995, The transport of atmospheric trace gases to the water table-implications for groundwater dating with chlorofluorocarbons and krypton85: Water Resources Research, v. 31, no. 3, p. 263-270.

Coplen, T.B., 1993, Uses of environmental isotopes, chap. 10 of Alley, W.M., ed., Regional ground-water quality: New York, Van Nostrand Reinhold, p. 227-254.

Coplen, T.B., Herczeg, A.L., and Barnes, Chris, 2000, Isotope engineering - using stable isotopes of the water molecule to solve practical problems, chap. 3 of Cook, P.G., and Herczeg, A.L., eds., Environmental tracers in subsurface hydrology: Boston, Kluwer Academic Publications, p. 79-110.

Coplen, T.B., Hopple, J.A., Böhlke, J.K., Peiser, H.S., Rieder, S.E., Krouse, H.R., Rosman, K.J.R., Ding, T., Vocke, R.D., Jr., Révész, K.M., Lamberty, A., Taylor, P., and De Bièvere, P., 2002, Compilation of minimum and maximum isotope ratios of selected elements in naturally occurring terrestrial materials and reagents: U.S. Geological Survey WaterResources Investigations Report 01-4222, 98 p.

Coplen, T.B., and Kendall, Carol, 2000, Stable hydrogen and oxygen isotope ratios for selected sites of the U.S. Geological Survey's NASQAN and benchmark surface-water networks: U.S. Geological Survey Open-File Report 00-160, $490 \mathrm{p}$.

Craig, Harmon, 1961, Isotopic variations in meteoric waters: Science, v. 133, p. 1702-1703. 
Crist, M.A., and Borchert, W.B., 1972, The ground-water system in southeastern Laramie County, Wyoming: U.S. Geological Survey Open-File Report 72-80, 51 p.

Darton, N.H., 1903, Preliminary report on the geology and water resources of Nebraska west of the one hundred and third meridian: U.S. Geological Survey Professional Paper 17, 69 p., 43 plates.

Davis, S.N., and DeWiest, R.J.M., 1966, Hydrogeology: New York, Wiley and Sons, 463 p.

Diffendal, R.F., Jr., 1990, The Sidney Gravel and Kimball Formation, supposed parts of the Ogallala Group (Neogene), are not objectively mappable units, in Gustavson, T.C., ed., Geologic framework and regional hydrology-Upper Cenozoic Blackwater Draw and Ogallala Formations, Great Plains: Austin, Texas, University of Texas, p. 23-38.

Dowdy, Shirley, and Wearden, Stanley, 1991, Statistics for research (2d ed.) - Wiley series in probability and mathematical statistics: New York, Wiley and Sons, 629 p.

Ekwurzel, Brenda, Schlosser, Peter, Smethie, W.M., Jr., Plummer, L.N., Busenberg, Eurybiades, Michel, R.L., Weppernig, Ralf, and Stute, Martin, 1994, Dating of shallow groundwater - comparison of the transient tracers ${ }^{3} \mathrm{H} /{ }^{3} \mathrm{He}$, chlorofluorocarbons and ${ }^{85} \mathrm{Kr}$ : Water Resources Research, v. 30 , no. 6 , p. $1693-1708$.

Engberg, R.A., 1984, Appraisal of data for ground-water quality in Nebraska: U.S. Geological Survey Water-Supply Paper 2245, 54 p.

Engberg, R.A., and Druliner, A.D., 1988, Nebraska groundwater resources, in U.S. Geological Survey national water summary, 1986-hydrologic events and groundwater resources: U.S. Geological Survey Water-Supply Paper 2325, p. 347-354.

Engberg, R.A., and Spalding, R.F., 1979, Groundwater quality atlas of Nebraska: Lincoln, University of Nebraska-Lincoln, Conservation and Survey Division Resource Atlas no. $3,39 \mathrm{p}$.

Erdmann, D.E., and Thomas, J.D., 1985, Quality assurance of U.S. Geological Survey water-quality field measurements, in Taylor, J.K., and Stanley, T.W., eds., Quality assurance for environmental measurements: Philadelphia, American Society for Testing and Materials, ASTM STP 867, 441 p.

Feggestad, A.J., Jacobs, P.M, Miao, Xiaodong, and Mason, J.A., 2004, Stable carbon isotope record of Holocene environmental change in the central Great Plains: Physical Geography, v. 25, no. 2, p. 170-190.

Fenneman, N.M., 1946, Physical divisions of the United States: U.S. Geological Survey map, scale 1:7,000,000.
Fontes, J.-Ch., 1980, Environmental isotopes in groundwater hydrology, chap. 3 of Fritz, P., and Fontes, J.-Ch., eds., Handbook of environmental isotope geochemistry: Amsterdam, Elsevier Scientific, The Terrestrial Environment, A, v. 1, p. 75-140.

Fontes, J.-Ch., and Garnier, J.M., 1979, Determination of the initial ${ }^{14} \mathrm{C}$ activity of the total dissolved carbon-a review of the existing models and a new approach: Water Resources Research, v 15, no. 2, p. 399-413.

Goodwin, R.G., and Diffendal, R.F., Jr., 1987, Paleohydrology of some Ogallala (Neogene) streams in the southern Panhandle of Nebraska: The Society of Economic Paleontologists and Mineralogists Special Publication no. 39, p. 149-157.

Gottula, J.J., 1997, A study of nonpoint source ground water contamination in eastern Cheyenne County - a ground water management area report: Nebraska Department of Environmental Quality, 85 p.

Gutentag, E.D., Heimes, F.J., Krothe, N.C., Luckey, R.R., and Weeks, J.B., 1984, Geohydrology of the High Plains aquifer in parts of Colorado, Kansas, Nebraska, New Mexico, Oklahoma, South Dakota, Texas, and Wyoming: U.S. Geological Survey Professional Paper 1400-B, 63 p.

Harvey, F.E., 2005, Stable hydrogen and oxygen isotope composition of precipitation in northeastern Colorado: Journal of the American Water Resources Association, v. 41, no. 2, p. $447-459$.

Harvey, F.E., and Welker, J.M., 2000, Stable isotopic composition of precipitation in the semi-arid north-central portion of the U.S. Great Plains: Journal of Hydrology, v. 238, p. 90-109.

Helsel, D.R., and Hirsch, R.M., 1992, Statistical methods in water resources: Amsterdam, Elsevier Publications, 522 p.

Hem, J.D., 1992, Study and interpretation of the chemical characteristics of natural water ( $3 \mathrm{~d}$ ed.): U.S. Geological Survey Water-Supply Paper 2254, 263 p.

High Plains Regional Climate Center, 2006, Sidney 6 NNW, National climatic data center 1971-2000 monthly normals: Information available on Web, accessed April 10, 2006, at http://www.hprcc.unl.edu/cgi-bin/cli_perl_lib/cliMAIN. pl?ne 7830

International Atomic Energy Agency (IAEA), 1992, Statistical treatment of data on environmental isotopes in precipitation: Vienna, IAEA, Technical Reports Series no. 331, 781 p.

Kalin, R.M., 2000, Radiocarbon dating of groundwater systems, chap. 4 of Cook, P.G., and Herczeg, A.L., eds., Environmental tracers in subsurface hydrology: Boston, Kluwer Academic Publishers, p. 111-144. 
Kendall, Carol, and Caldwell, E.A., 1998, Fundamentals of isotope geochemistry, chap. 2 of Kendall, Carol, and McDonnell, J.J., eds., Isotope tracers in catchment hydrology: Amsterdam, Elsevier Publications, p. 51-86.

Kolpin, D.W., and Burkart, M.R., 1991, Work plan for regional reconnaissance for selected herbicides and nitrate in ground water of the mid-continental United States, 1991: U.S. Geological Survey Open-File Report 91-59, 18 p.

Lapham, W.W., Wilde, F.D., and Koterba, M.T., 1997, Guidelines and standard procedures for studies of ground-water quality - selection and installation of wells, and supporting documentation: U.S. Geological Survey Water-Resource Investigations Report 96-4233, 110 p.

Lowry, M.E., 1966, The White River Formation as an aquifer in southeastern Wyoming and adjacent parts of Nebraska and Colorado: U.S. Geological Survey Professional Paper 550-D, p. 217-222.

Lucas, L.L., and Unterweger, M.P., 2000, Comprehensive review and critical evaluation of the half-life of tritium: Journal of Research of the National Institute of Standards and Technology, v. 105, no. 4, p. 541-549.

Lugn, A.L., 1935, The Pleistocene geology of Nebraska: Nebraska Geological Survey Bulletin, v. 10, 223 p.

Mann, W.B., Urterweger, M.P., and Coursey, B.M., 1982, Comments of the NBS tritiated-water standards and their use: International Journal of Applied Radiatomical Isotopes, v. 33, p. 383-386.

McCrea, J.M., 1950, On the isotope chemistry of carbonates and a paleotemperature scale: The Journal of Chemical Physics, v. 18, p. 849-857.

McDonald, M.G., and Harbaugh, A.W., 1988, A modular three-dimensional finite-difference ground-water flow model: U.S. Geological Survey Techniques of WaterResources Investigations, book 6, chap. A1, 586 p.

Meinzer, O.E., 1923, The occurrence of ground water in the United States, with a discussion of principles: U.S. Geological Survey Water-Supply Paper 489, 321 p.

Morris, R.A., Miller, T.M., Viggiano, A.A., Paulson, F.J., Solomon, S., and Reid, G., 1995, Effects of electron and ion reactions on atmospheric lifetimes of fully fluorinated compounds: Journal of Geophysical Research-Atmosphere, v. 100 D1, p. 1287-1294.

Nebraska Department of Natural Resources, 2002, Why register wells?: Information available on Web, accessed April 5, 2007, at http://dnr.ne.gov/docs/groundwat.html
Nebraska Department of Natural Resources, 2006, Registered groundwater wells data bank database: Information available on Web, accessed April 5, 2007, at http://dnrdata.dnr. ne.gov/wellssql/viewsql.asp?welltype $=I \&$ CountyNum $=17$

Ogle, K.M., and Hallberg, L.L., 2000, Hydrogeologic and geochemical characteristics of the Ogallala and White River aquifers, Cheyenne, Wyoming: U.S. Geological Survey Water-Resources Investigations Report 00-4188, 1 plate.

Parkhurst, D.L., and Plummer, L.N., 1993, Geochemical models, chap. 9 of Alley, W.M., ed., Regional ground-water quality: New York, Van Nostrand Reinhold, p. 199-225.

Peckenpaugh, J.M., and Dugan, J.T., 1983, Hydrogeology of parts of the Central Platte and Lower Loup Natural Resources Districts, Nebraska: U.S. Geological Survey Water-Resources Investigations Report 83-4219, 100 p., 3 plates.

Plummer, L.N., and Busenberg, Eurybiades, 2000, Chlorofluorocarbons, chap. 15 of Cook, P.G., and Herczeg, A.L., eds., Environmental tracers in subsurface hydrology: Boston, Kluwer Academic Publishers, p. 442-478.

Plummer, L.N., Prestemon, E.C., and Parkhurst, D.L., 1994, An interactive code (NETPATH) for modeling NET geochemical reactions along a flow PATH_-version 2: U.S. Geological Survey Water-Resources Investigations Report 94-4169, 130 p.

Rapp, J.R., Visher, F.N., and Littleton, R.T., 1957, Geology and ground-water resources of Goshen County, Wyoming: U.S. Geological Survey Water-Supply Paper 1377, 145 p.

Ravishankara, R.A., Solomon, S., Turnipseed, A.A., and Warren, R.F., 1993, Atmospheric lifetimes of long-lived species: Science, v. 259, p. 194-199.

Sibray, S.S., and Zhang, Y.K., 1994, Three-dimensional modeling of hydraulic behavior of a highly conductive secondary permeability zone in the Brule Formation, in Warner, J.W., and van der Heijde, Paul, eds., Proceedings of 1994 Groundwater Modeling Conference, Fort Collins, Colorado, August 10-12, 1994: Fort Collins, Colorado State University, p. 445-452.

Smith, Frank, 1969, Preliminary groundwater report-availability of groundwater for irrigation in Cheyenne County, Nebraska: Lincoln, University of Nebraska-Lincoln, Conservation and Survey Division, 89 p.

Solomon, D.K., and Cook, P.G., 2000, ${ }^{3} \mathrm{H}$ and ${ }^{3} \mathrm{He}$, chap. 13 of Cook, P.G., and Herczeg, A.L., eds., Environmental tracers in subsurface hydrology: Boston, Kluwer Academic Publishers, p. 397-424. 
Solomon, D.K., Cook, P.G., and Sanford, W.E., 1998, Dissolved gases in subsurface hydrology, chap. 9 of Kendall, Carol, and McDonnell, J.J., eds., Isotope tracers in catchment hydrology: Amsterdam, Elsevier Publications, p. 291-318.

South Platte Natural Resources District, 1994, South Platte Natural Resources District ground water management plan: Sidney, Nebraska, South Platte Natural Resources District, various pagination.

Steele, G.V., Cannia, J.C., Sibray, S.S., and McGuire, V.L., 2005, Age and quality of ground water and sources of nitrogen in the surficial aquifers in Pumpkin Creek Valley, western Nebraska, 2000: U.S. Geological Survey Scientific Investigations Report 2005-5157, 68 p.

Stuiver, Minze, and Polach, H.A., 1977, Discussion-reporting of C-14 data: Radiocarbon, v. 19, no. 3, p. 355-363.

Swinehart, J.B., and Diffendal, R.F., Jr., 1997, Geologic map of the Scottsbluff $1^{\circ}$ x $2^{\circ}$ quadrangle, Nebraska and Colorado: U.S. Geological Survey Miscellaneous Investigations Series Map I-12545, scale 1:250,000.

Swinehart, J.B., Souders, V.L., DeGraw, H.M, and Diffendal, R.F., Jr., 1985, Cenozoic paleogeography of western Nebraska, in Flores, R.M., and Kaplan, S.S., eds., Cenozoic paleogeography of west-central United States: Denver, Colorado, Rocky Mountain Section-Society of Economic Paleontologists and Mineralogists, p. 213.

Szabo, Zoltan, Rice, D.E., Plummer, L.N., Busenberg, Eurybiades, Drenkard, Stefan, and Schlosser, Peter, 1996, Age dating of shallow groundwater with chlorofluorocarbons, tritium/helium 3, and flow path analysis, southern New Jersey coastal plain: Water Resources Research, v. 32, no. 4, p. 1023-1038.

Thatcher, L.L., Janzer, V.J., and Edwards, K.W., 1977, Methods for determination of radioactive substances in water and fluvial sediments: U.S. Geological Survey Techniques of Water-Resources Investigations, book 5, chap A5, p. 79-81.

Tychsen, P.C., 1954, A sedimentation study of the Brule Formation in northwest Nebraska: Lincoln, University of Nebraska, doctoral dissertation, 189 p., 25 plates.

University of Nebraska-Lincoln, 1996, Bedrock geology of Nebraska: Lincoln, Nebraska, University of NebraskaLincoln Conservation and Survey Division, digitized map, available on the Web, accessed July 20, 2006, at http://csd. unl.edu/general/gis-datasets.asp\#Bedrock_Geology

U.S. Army Corps of Engineers, 2000, Former Sioux Army Depot, Cheyenne County, Nebraska-investigation report, ammunition workshop area: Omaha District, Nebraska, 391 p., compact disk.
U.S. Census Bureau, 2006, Population finder-Sidney city, Nebraska: U.S. Census Bureau, information available on Web, accessed April 10, 2006, at http://www.census.gov

U.S. Department of Agriculture, 2006, Soil Survey Geographic (SSURGO) database for Cheyenne County, Nebraska: Natural Resources Conservation Service, information available on the Web, accessed February 22, 2007, at http://soildatamart.nrcs.usda.gov/

U.S. Environmental Protection Agency, 2002, List of drinking water standards \& MCLs-National Primary and Secondary Drinking-Water Regulations: U.S. Environmental Protection Agency, Office of Ground Water and Drinking Water, information available on Web, accessed April 12, 2005, at http://www.epa.gov/safewater/mcl.htm

U.S. Geological Survey, 2005a, Reston Chlorofluorocarbon Laboratory: Information available on Web, accessed April 22, 2005, at http://water.usgs.gov/lab/ chlorofluorocarbons/sampling/bottles

U.S. Geological Survey, 2005b, Reston Chlorofluorocarbon Laboratory: Information available on Web, accessed July 18, 2005, at http://water.usgs.gov/lab/3h3he/sampling

U.S. Geological Survey, 2005c, Reston Chlorofluorocarbon Laboratory: Information available on Web, accessed June 1, 2006, at http://water.usgs.gov/lab/software/air_curve

U.S. Geological Survey, 2006a, The geologic time scale: Information available on Web, accessed October 26, 2006, at http://vulcan.wr.usgs.gov/Glossary/geo_time_scale.html

U.S. Geological Survey, 2006b, National Water Quality Laboratory-laboratory evaluation studies: Branch of Quality Assurance (BQS) studies, information available on Web, accessed May 7, 2007, at http://nwql.usgs.gov/Public/ Perfomance/publiclabpe.html

Wang, Yang, Huntington, T.G., Osher, L.J., Wassenaar, L.I., Trumbore, S.E., Amundson, R.G., Harden, J.W., McKnight, D.M., Schiff, S.L, Aiken, G.R., Lyons, W.B., Aravena, R.O., and Baron, J.S., 1998, Carbon cycling in terrestrial environments, chap. 17 of Kendall, Carol, and McDonnell, J.J., eds., Isotope tracers in catchment hydrology: Amsterdam, Elsevier Publications, p. 577-610.

Wilde, F.D., ed., 2004, Cleaning of equipment for water sampling (version 2), in Wilde, F.D., Radtke, D.B., Gibs, Jacob, and Iwatsubo, R.T., eds., National field manual for the collection of water-quality data: U.S. Geological Survey Techniques of Water-Resources Investigations, book 9, chap. A3, information available on Web, accessed April 22, 2005, at http://water.usgs.gov/owq/FieldManual/chapter3/ Ch3_contents.html 
Wilde, F.D., and Radtke, D.B., eds., 1999, Field measurements, in Wilde, F.D., Radtke, D.B., Gibs, Jacob, and Iwatsubo, R.T., eds., National field manual for the collection of water-quality data: U.S. Geological Survey Techniques of Water-Resources Investigations, book 9, chap. A6, information available on Web, accessed April 22, 2005, at

http://water.usgs.gov/owq/FieldManual/chapter6/ Ch6_contents.html

Wilde, F.D., Radtke, D.B., Gibs, Jacob, and Iwatsubo, R.T. eds., 1999, Collection of water samples, in Wilde, F.D., Radtke, D.B., Gibs, Jacob, and Iwatsubo, R.T., eds., National field manual for the collection of water-quality data: U.S. Geological Survey Techniques of WaterResources Investigations, book 9, chap. A4, information available on Web, accessed April 22, 2005, at http://water.usgs.gov/owq/FieldManual/chapter4/html/ Ch4_contents.html
Wilde, F.D., Radtke, D.B., Gibs, Jacob, and Iwatsubo, R.T. eds., 2004, Processing of water samples, (version 2.2, 9/2004), in Wilde, F.D., Radtke, D.B., Gibs, Jacob, and Iwatsubo, R.T., eds., National field manual for the collection of water-quality data: U.S. Geological Survey Techniques of Water-Resources Investigations, book 9, chap. A5, information available on Web, accessed April 22, 2005, at http://water.usgs.gov/owq/FieldManual/chapter5/html/ Ch5_contents.html 
Evaluation of Ground Water Near Sidney, Western Nebraska, 2004-05 


\section{Appendix}


Table 4. Results of synoptic water-level survey of monitoring and irrigation wells near Sidney, western Nebraska, March 2005.

[NGVD29, National Geodetic Vertical Datum of 1929; NAVD88, North American Vertical Datum of 1988; --, not available or not applicable; U, undermined]

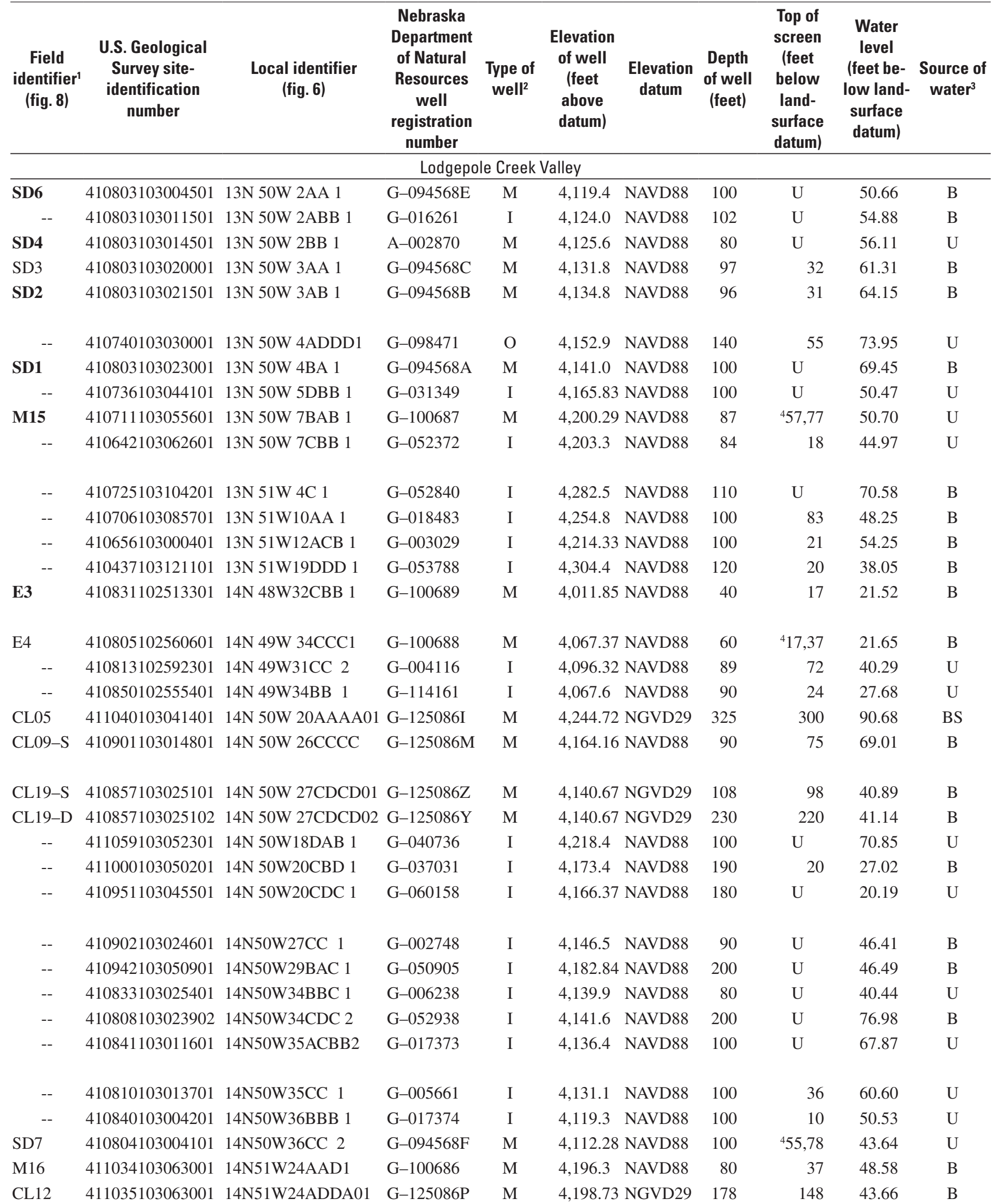


Table 4. Results of synoptic water-level survey of monitoring and irrigation wells near Sidney, western Nebraska, March 2005.—Continued

[NGVD29, National Geodetic Vertical Datum of 1929; NAVD88, North American Vertical Datum of 1988; --, not available or not applicable; U, undermined]

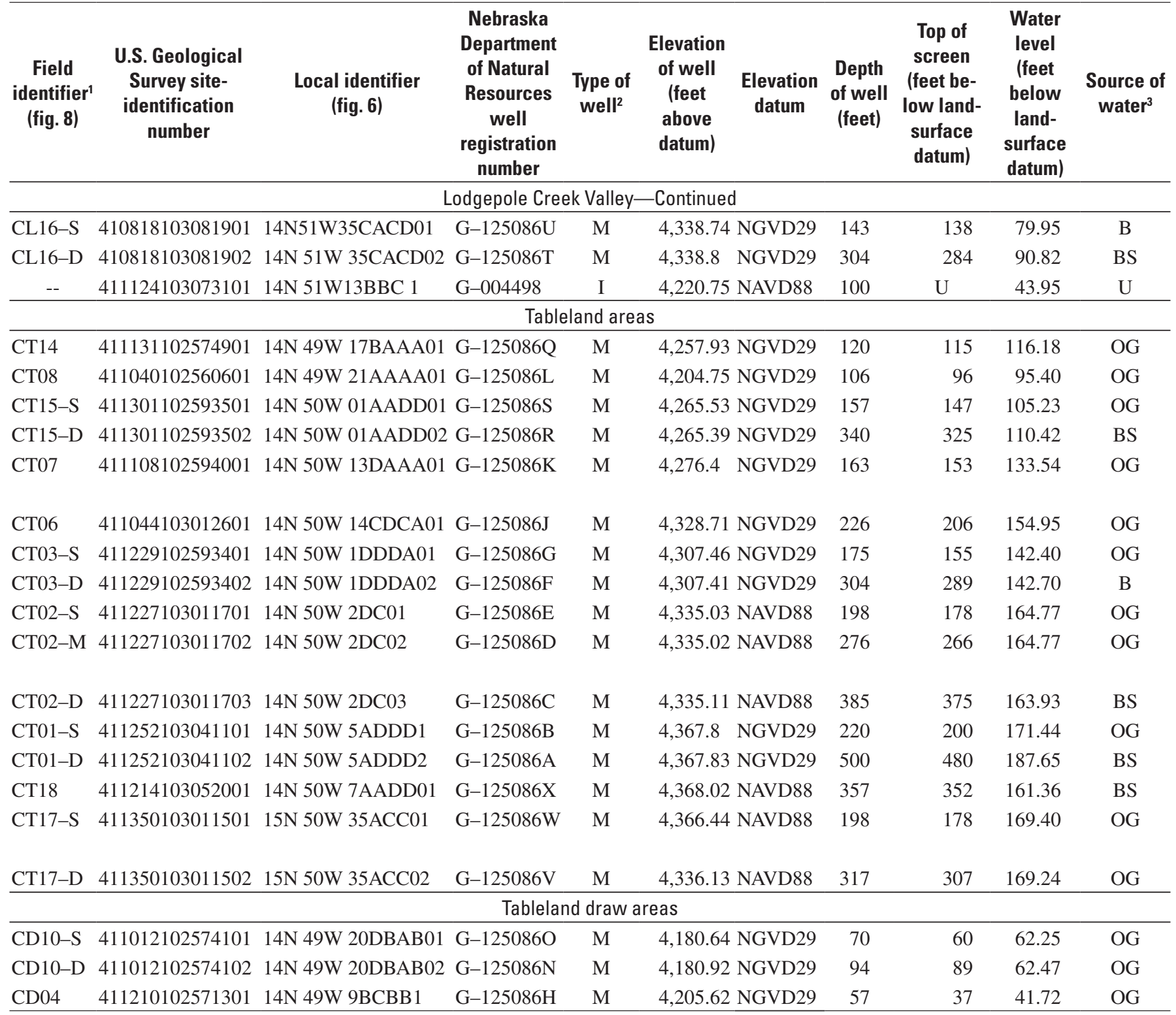

${ }^{1}$ Field identifier: S, shallow depth, M, intermediate depth; D, deep; bold identifier indicates monitoring well was not sampled during this study.

${ }^{2}$ Type of well: I, irrigation; M, monitoring, O, observation, $\mathrm{U}$, unused or undetermined.

${ }^{3}$ Source of water: B, Brule Formation (irrigation wells open to Brule Formation likely screened in fractured zones); BS, Brule Formation sand; OG, Ogallala Group; U, unknown or undetermined.

${ }^{4}$ Split screen (first number indicates top of shallowest screen-typically a 10 -foot screen separated by a 10 -foot section of casing). 


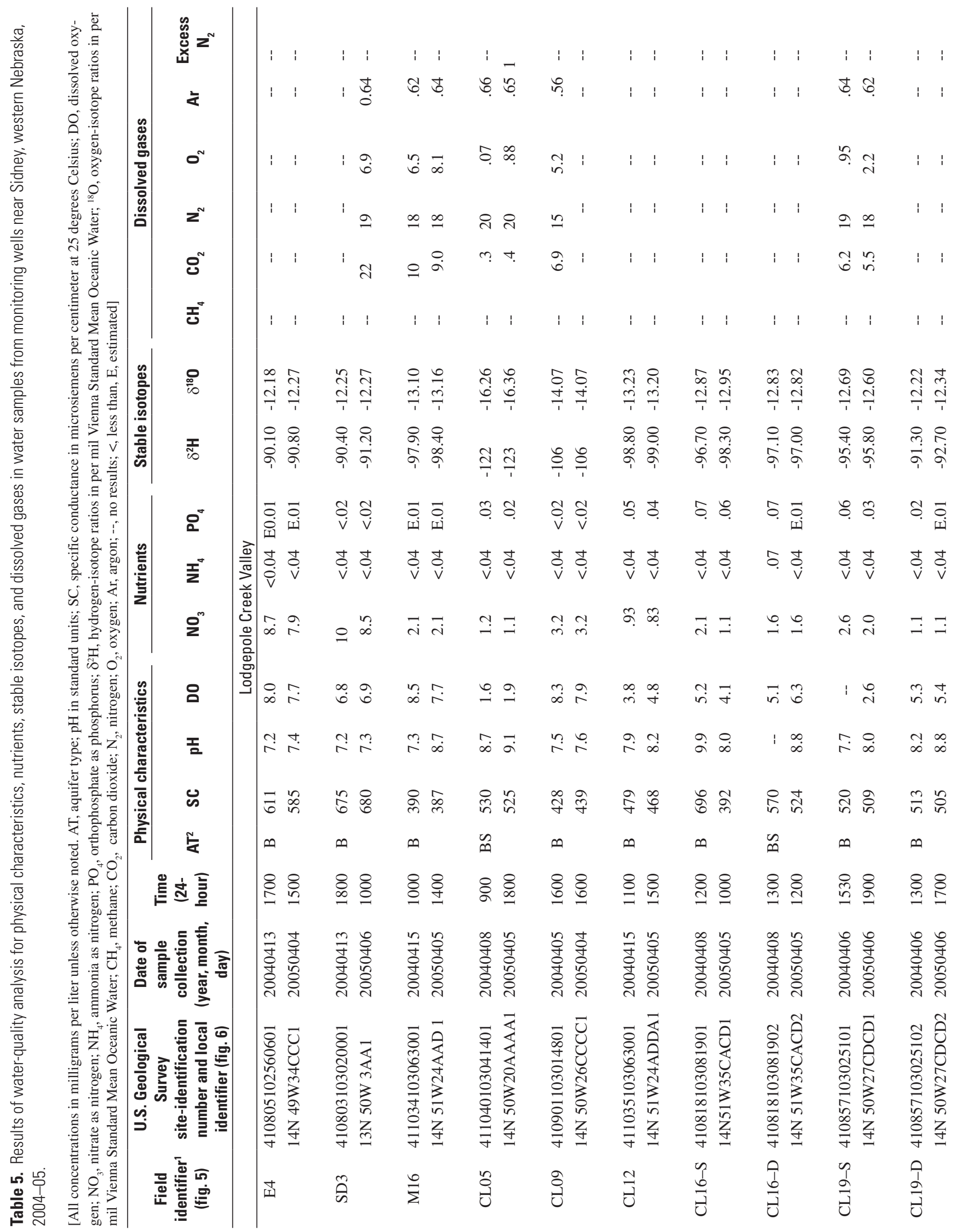




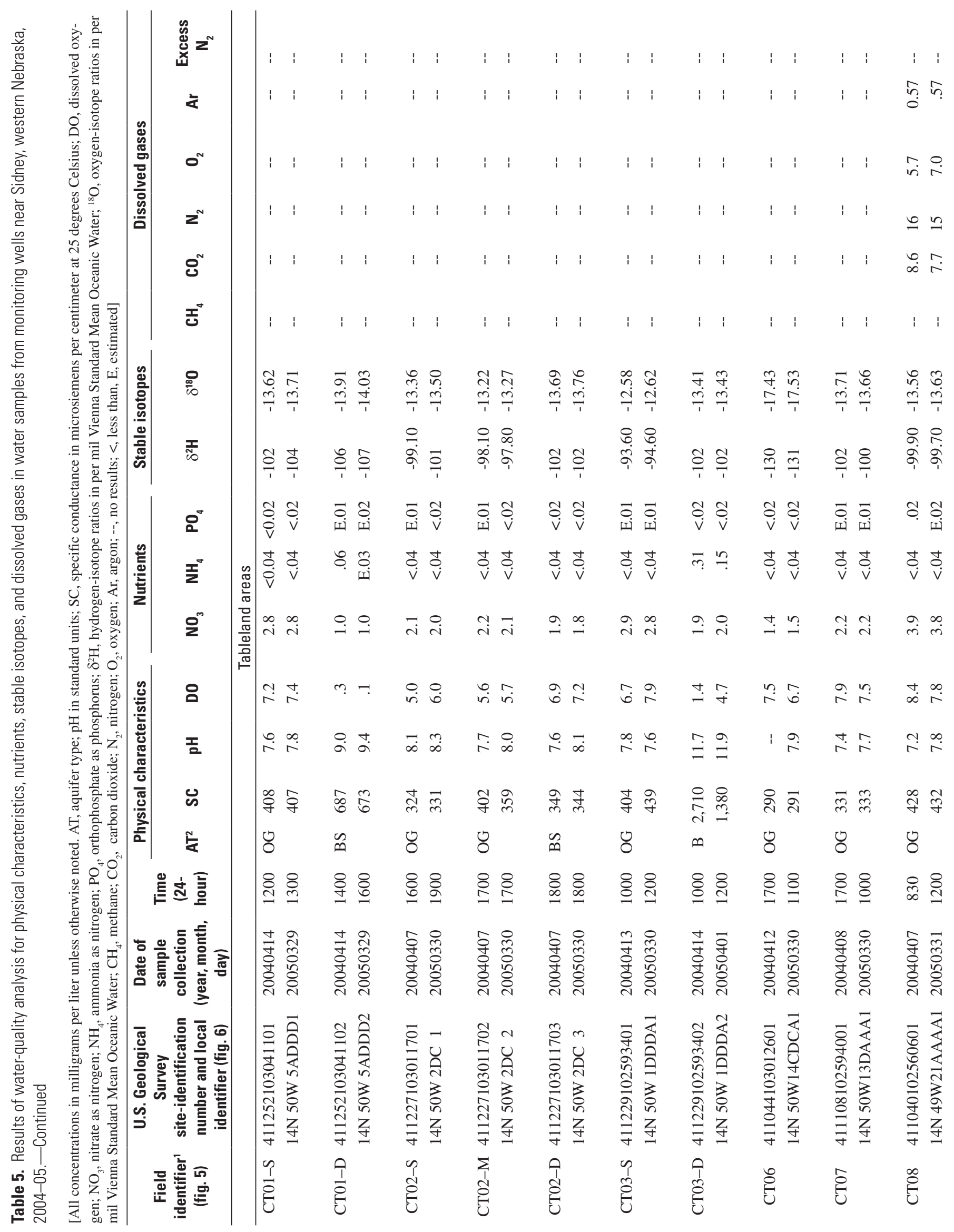




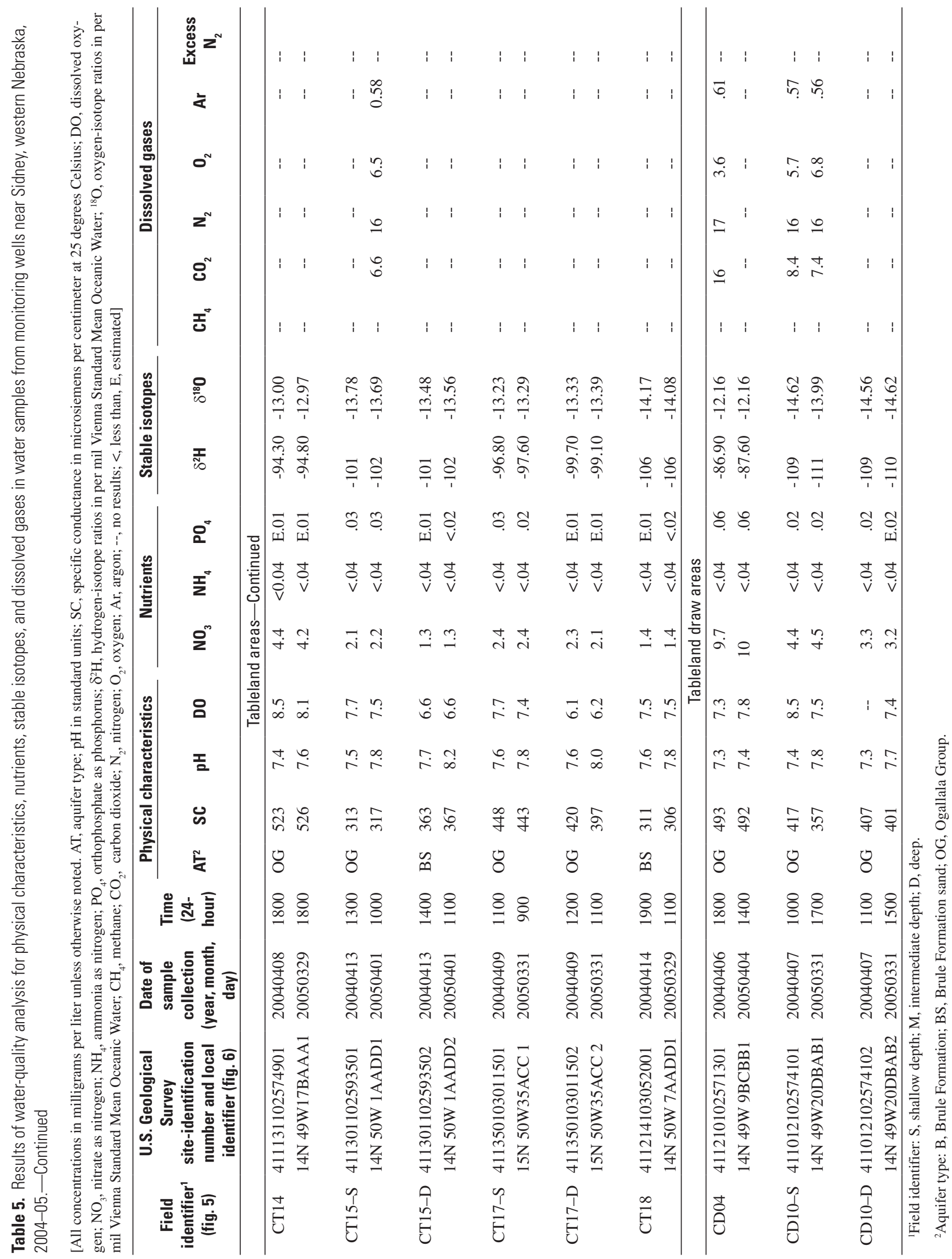




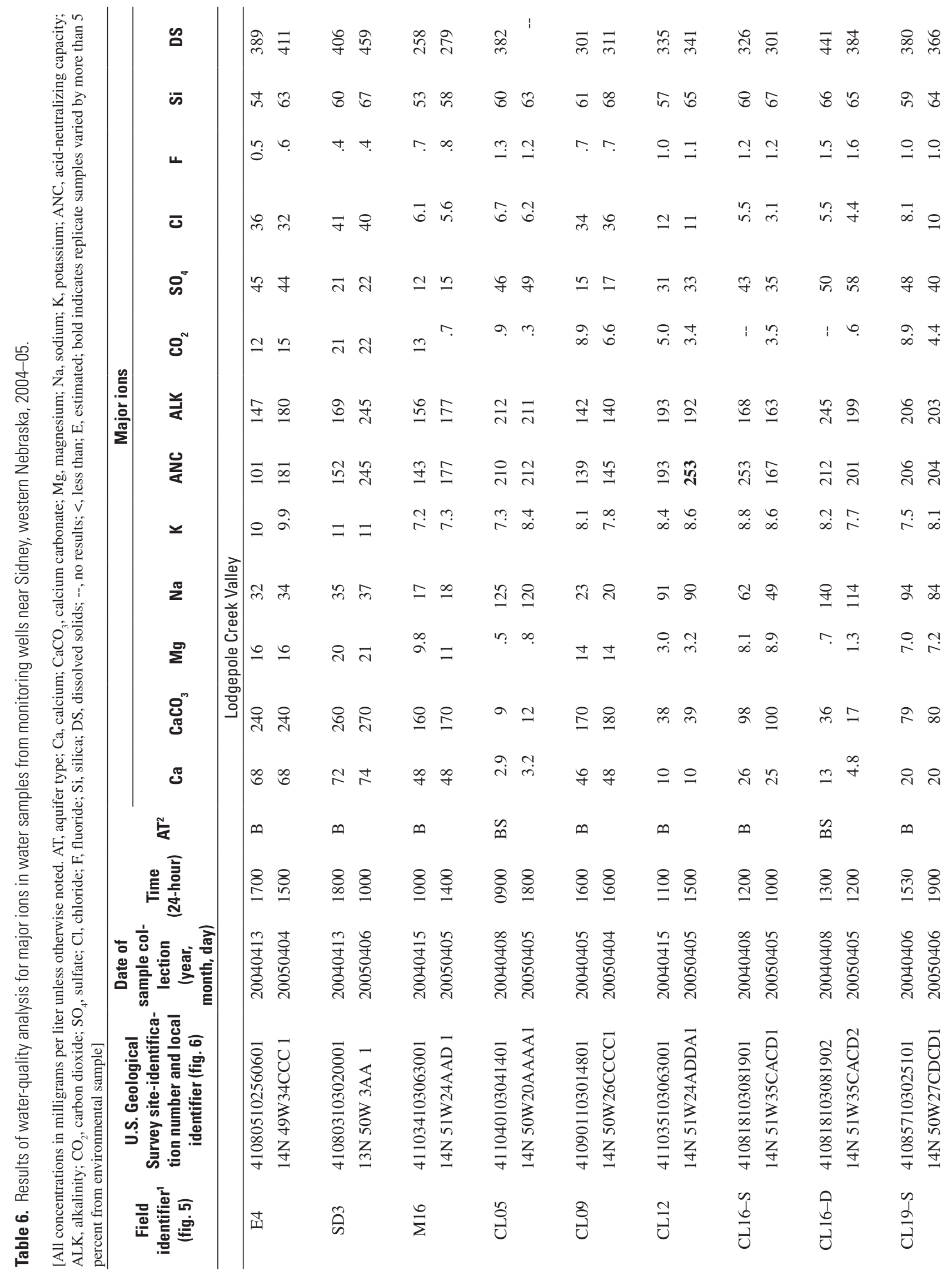




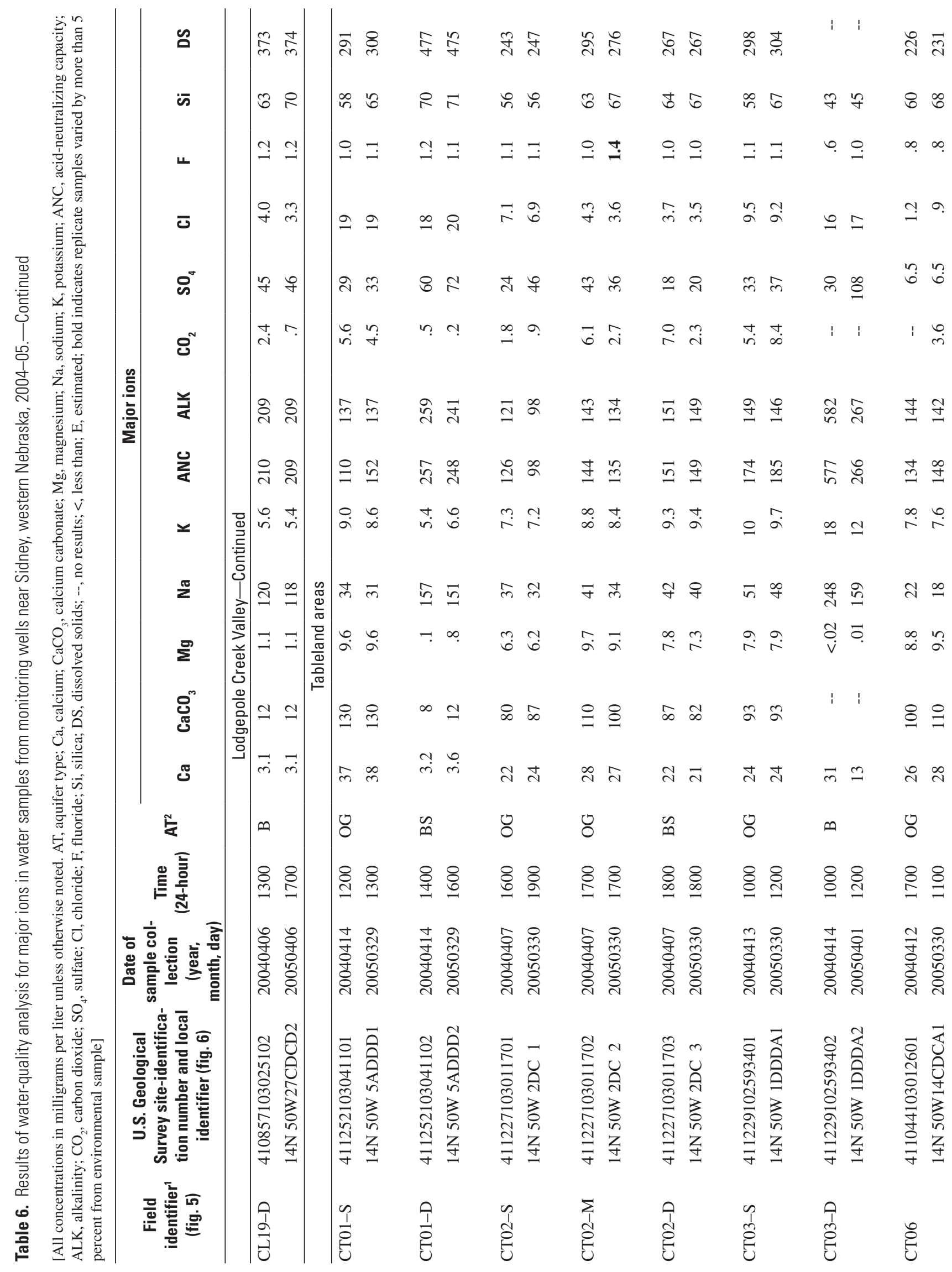




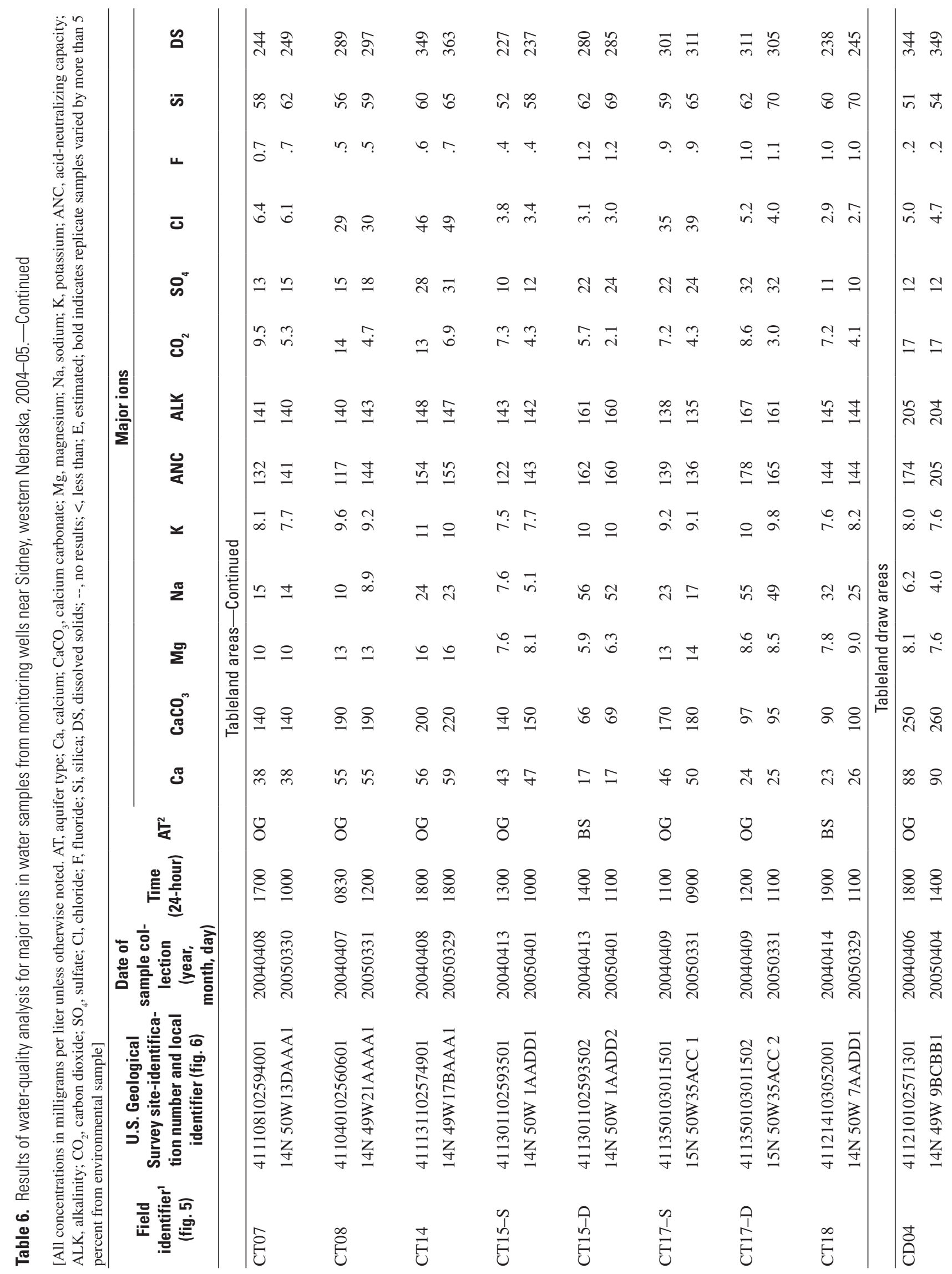




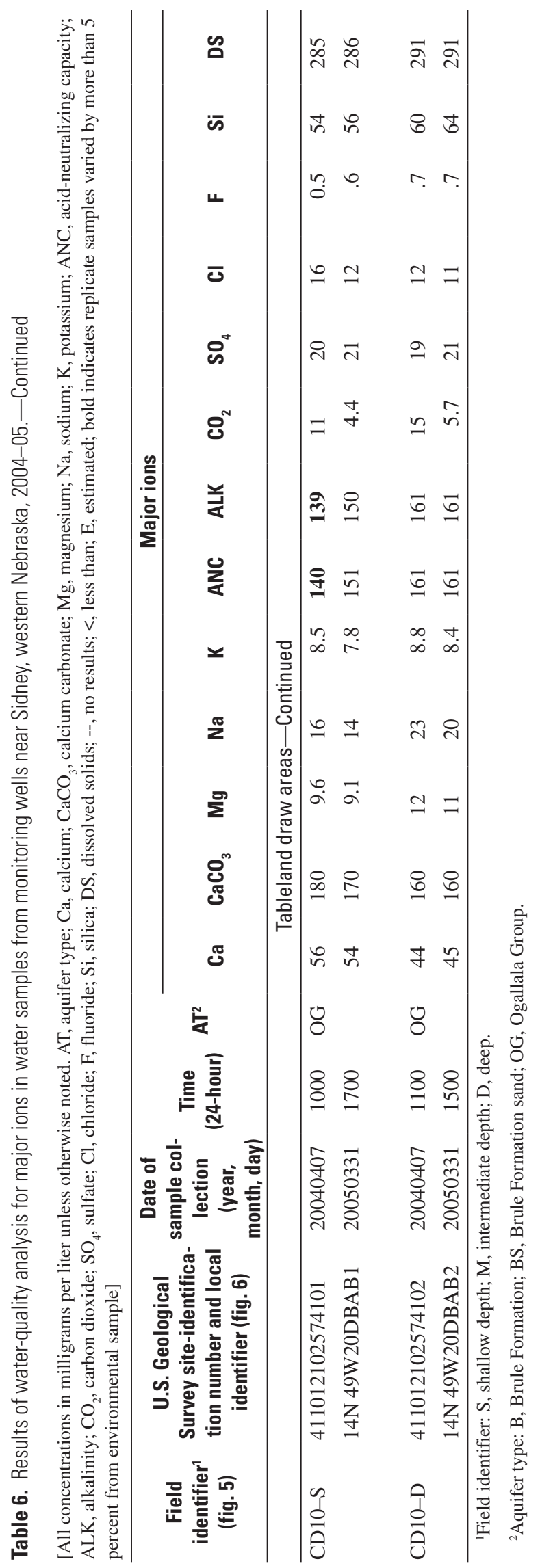




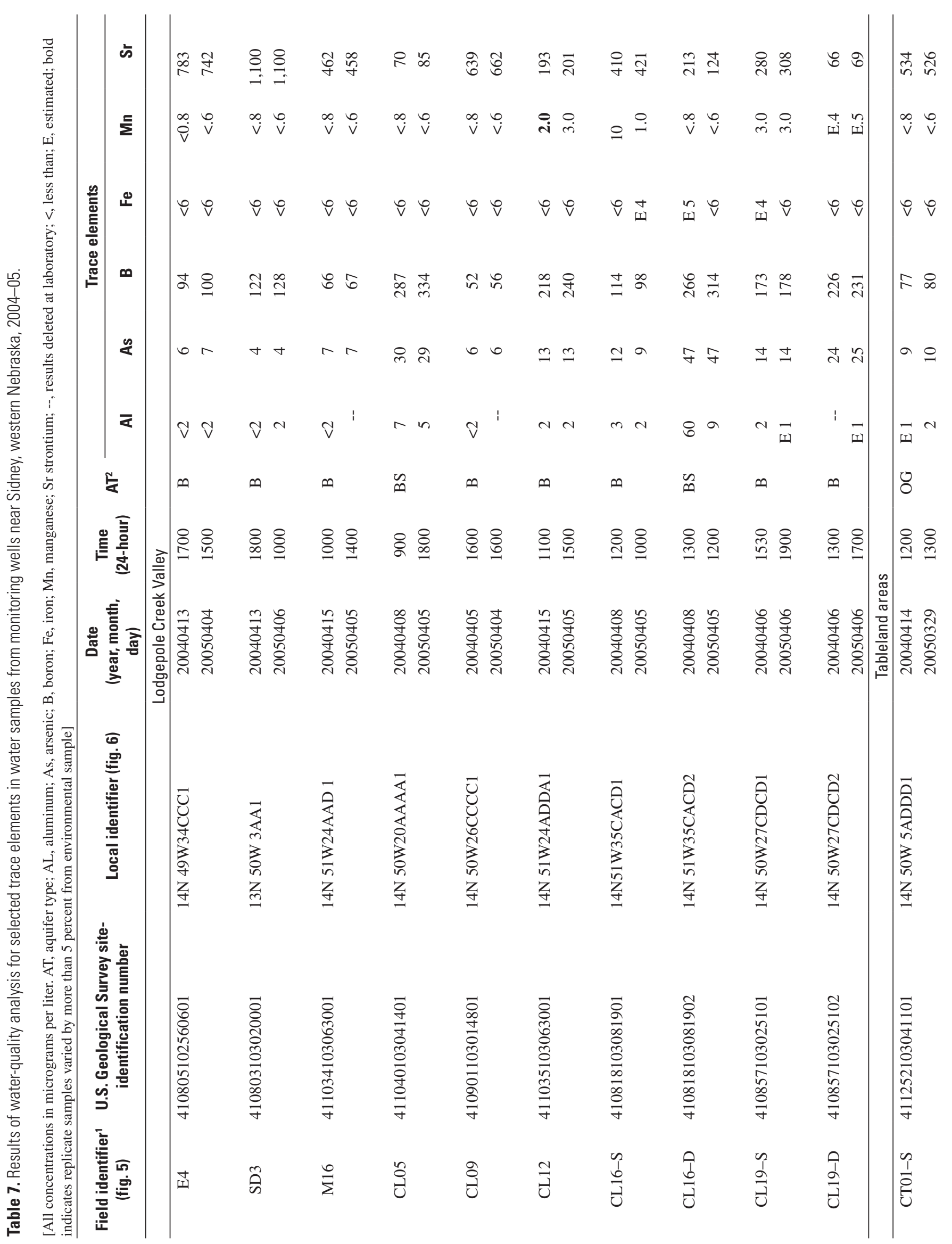




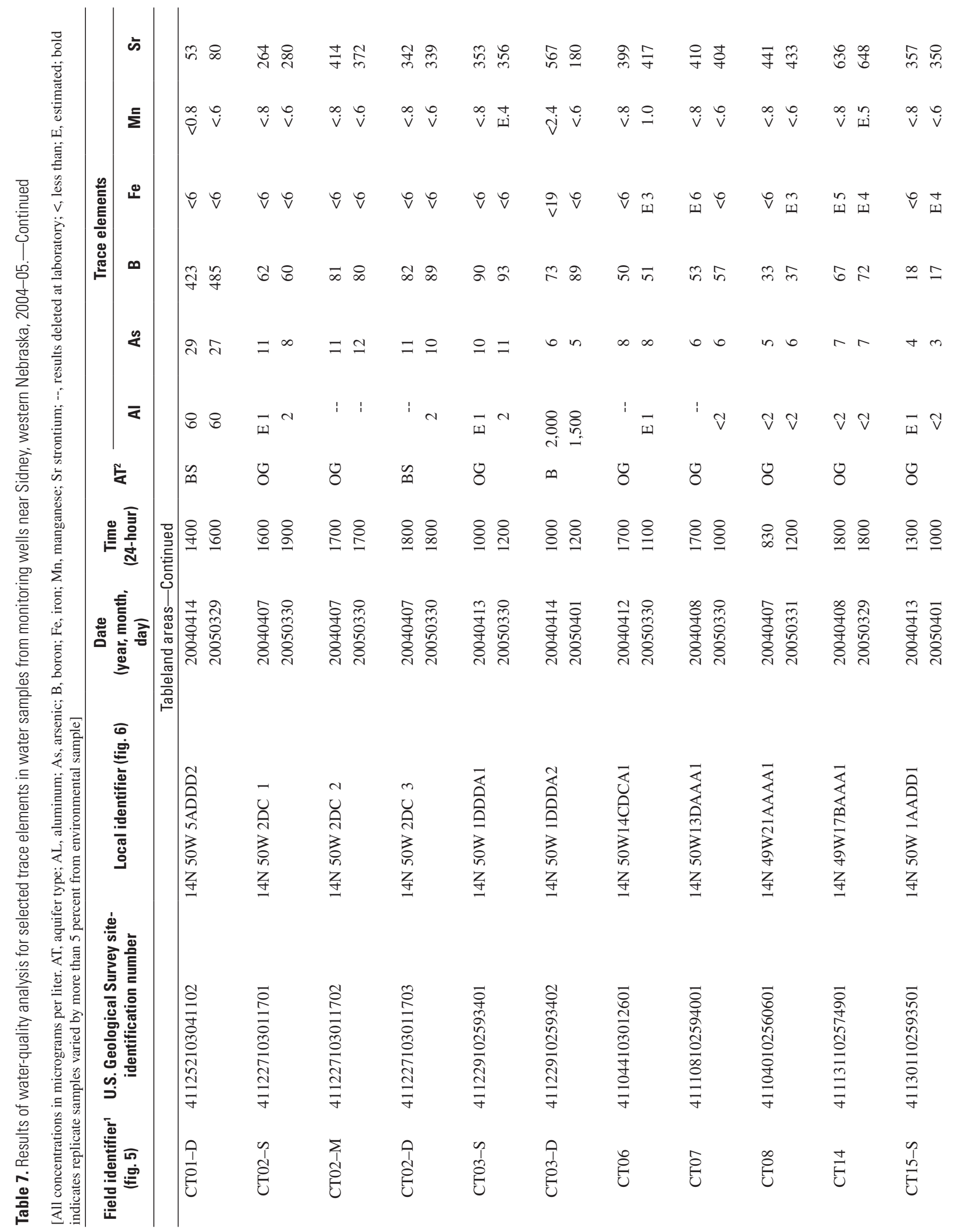




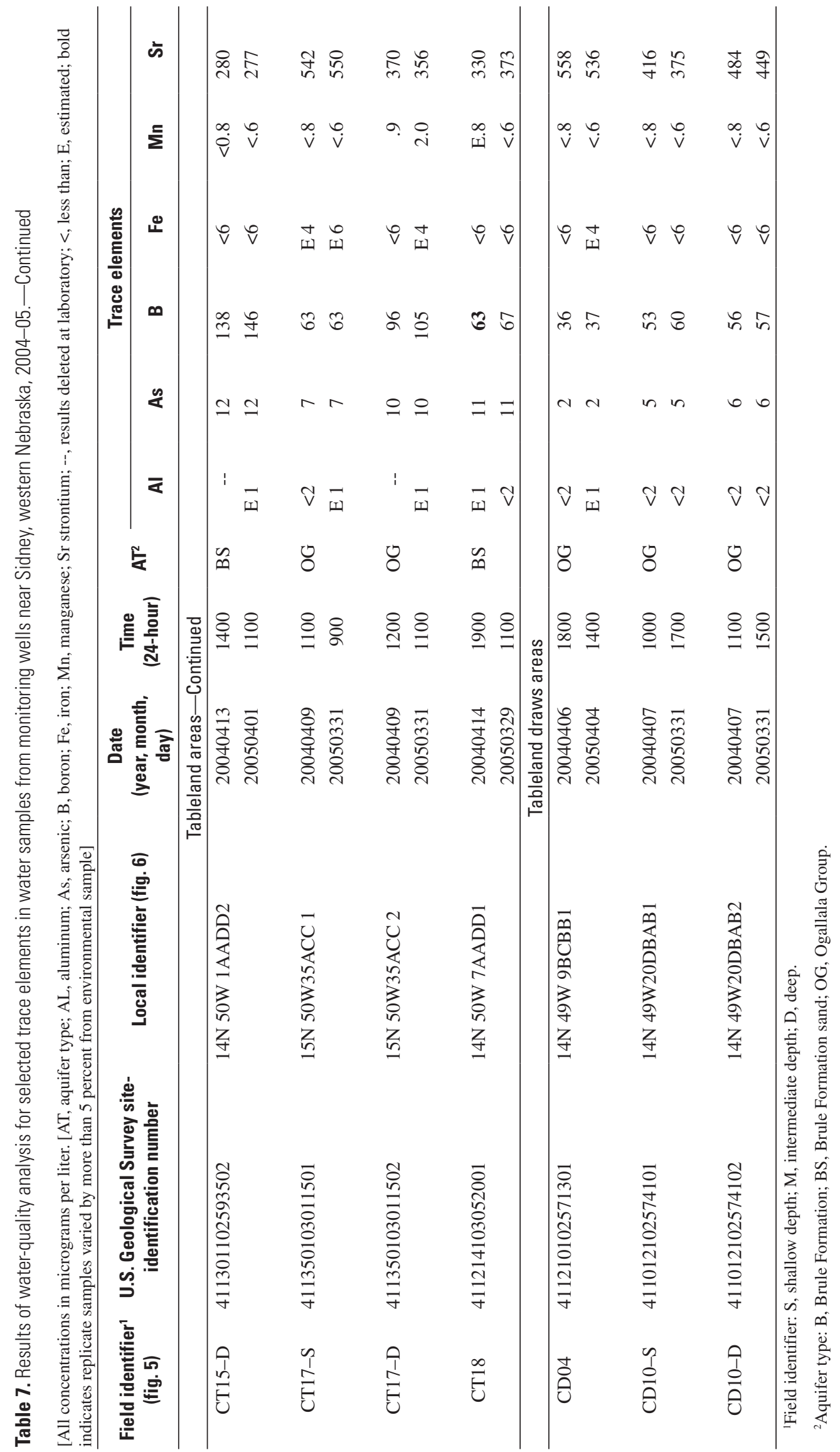




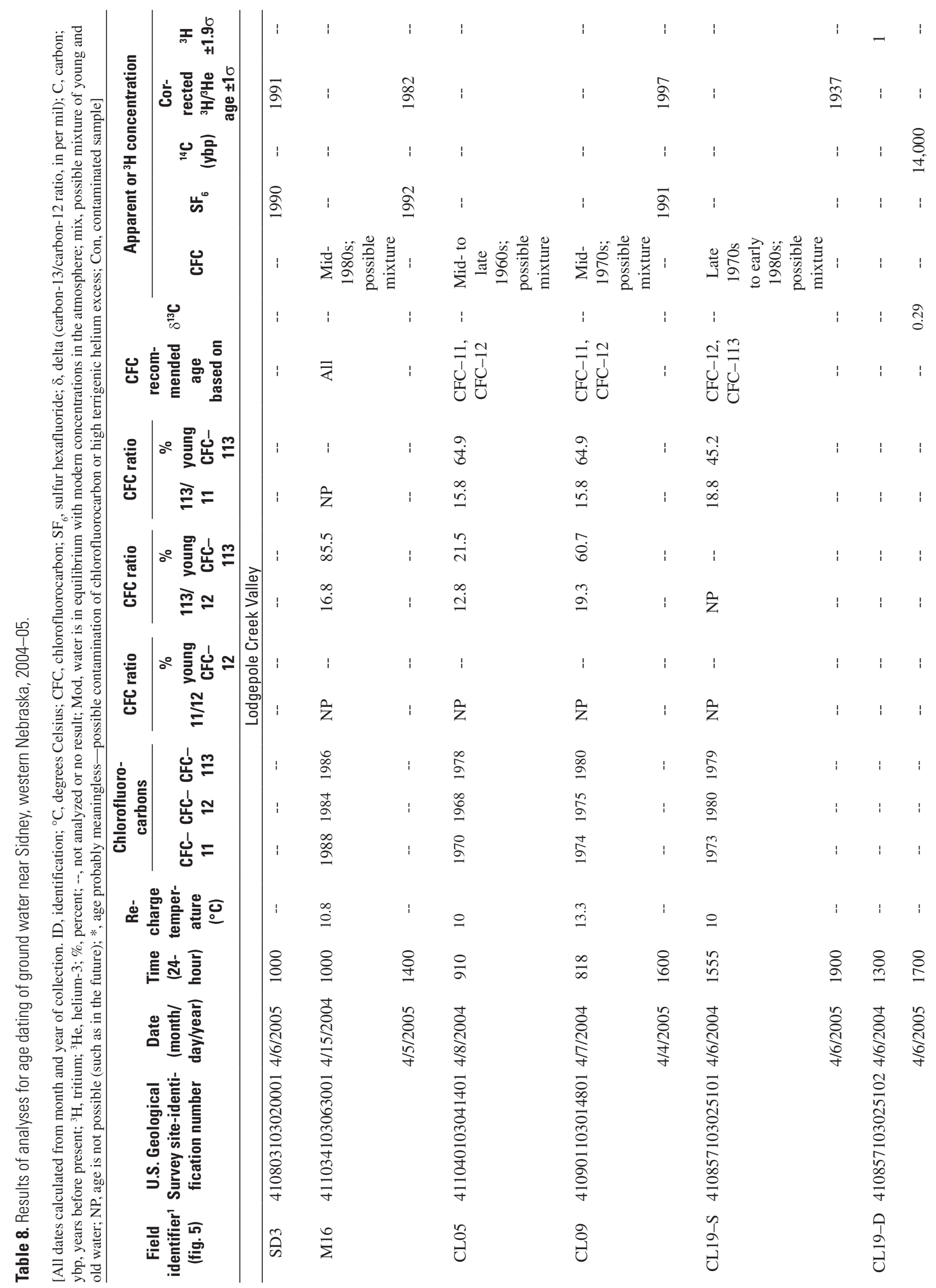




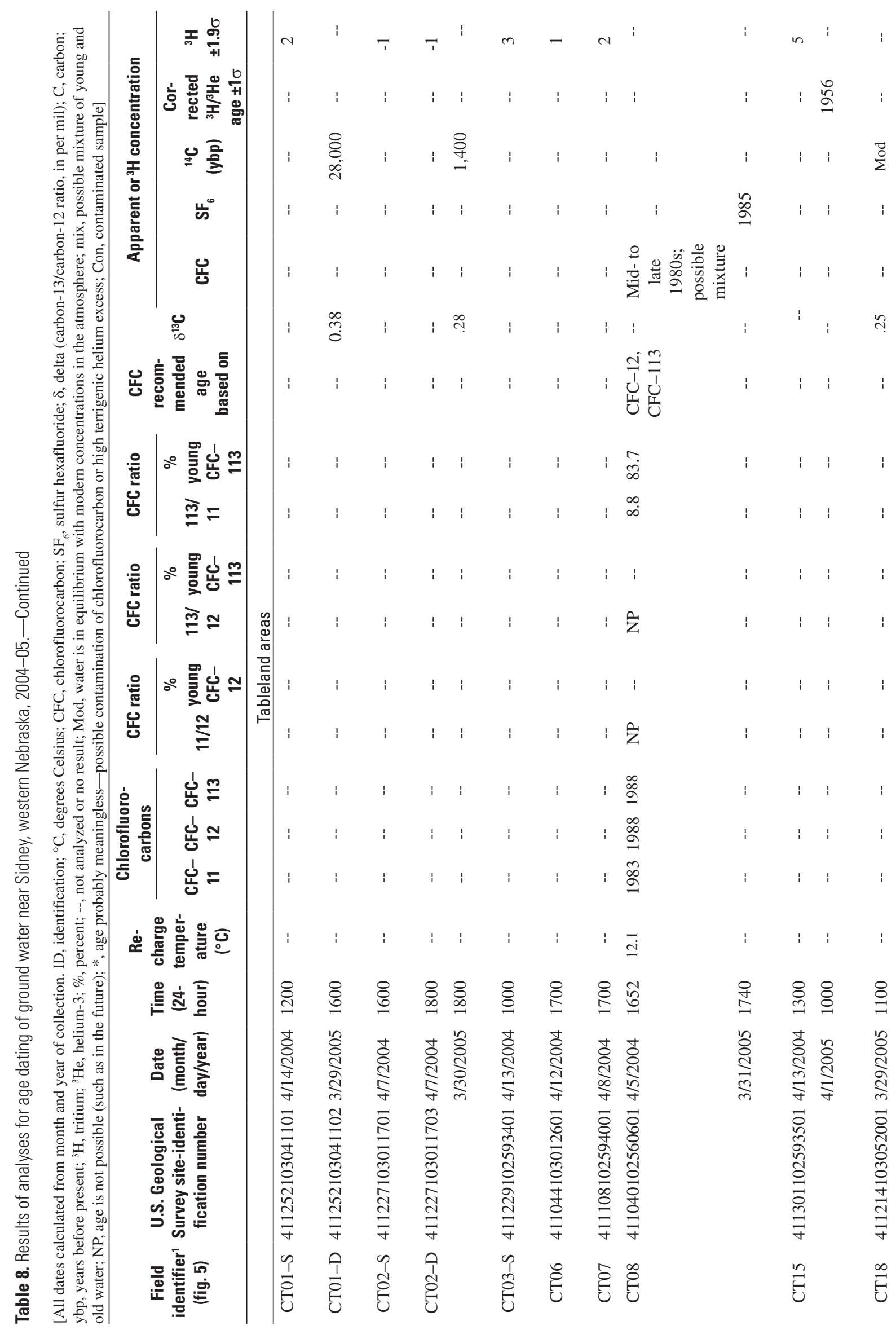




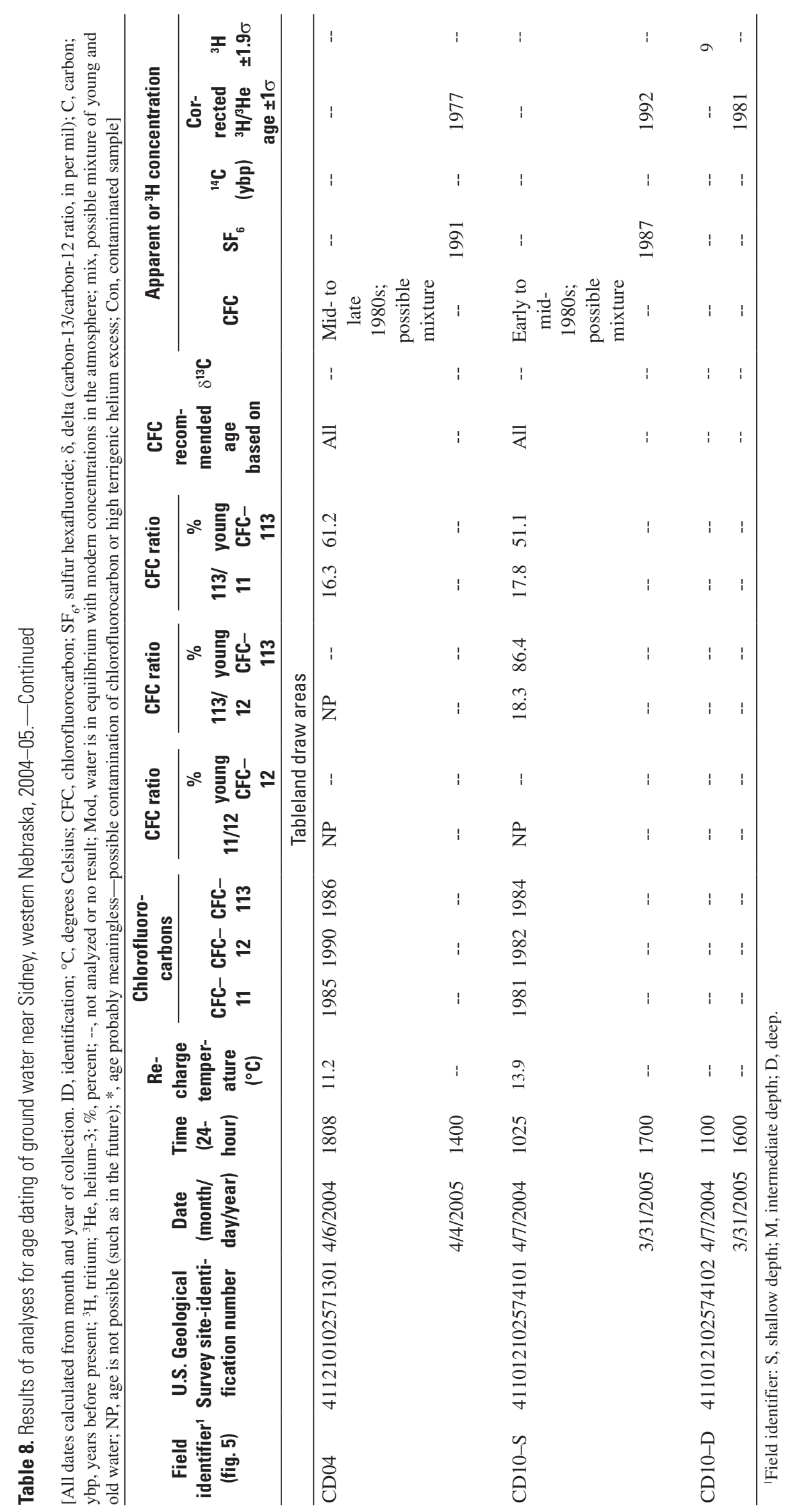


Prepared by Lawrence Publishing Service Center. Edited by L.J. Combs.

Illustrations and cover design by J.R. Hartley and M.D. Kemppainen. Layout and design by K.A. Hartley.

For more information concerning the research described in this report, contact:

U.S. Geological Survey

5231 South 19th Street

Lincoln, NE 68512

(402) 328-4100

http://ne.water.usgs.gov 
